Illinois State University

ISU ReD: Research and eData

Theses and Dissertations

$12-2-2013$

Disparity of Principal Accountability

Mary Kathryn Taylor

Illinois State University, kathy.taylor@risd41.org

Follow this and additional works at: https://ir.library.illinoisstate.edu/etd

Part of the Educational Administration and Supervision Commons, Educational Assessment, Evaluation, and Research Commons, and the Education Policy Commons

Recommended Citation

Taylor, Mary Kathryn, "Disparity of Principal Accountability" (2013). Theses and Dissertations. 27. https://ir.library.illinoisstate.edu/etd/27

This Dissertation is brought to you for free and open access by ISU ReD: Research and eData. It has been accepted for inclusion in Theses and Dissertations by an authorized administrator of ISU ReD: Research and eData. For more information, please contact ISUReD@ilstu.edu. 
THE DISPARITY OF PRINCIPAL ACCOUNTABILITY

\section{KATHRYN TAYLOR}

A Dissertation Submitted in Partial

Fulfillment of the Requirements

for the Degree of

DOCTOR OF PHILOSOPHY

Department of Educational Administration and Foundations

ILLINOIS STATE UNIVERSITY 
All rights reserved

INFORMATION TO ALL USERS

The quality of this reproduction is dependent upon the quality of the copy submitted.

In the unlikely event that the author did not send a complete manuscript and there are missing pages, these will be noted. Also, if material had to be removed, a note will indicate the deletion.

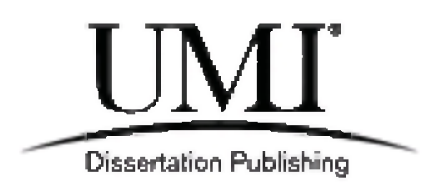

UMI 3604118

Published by ProQuest LLC (2013). Copyright in the Dissertation held by the Author.

Microform Edition () ProQuest LLC.

All rights reserved. This work is protected against unauthorized copying under Title 17, United States Code

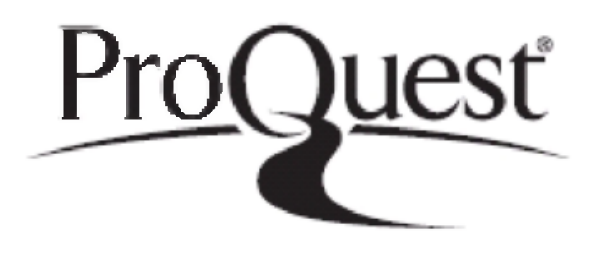

ProQuest LLC.

789 East Eisenhower Parkway

P.O. Box 1346

Ann Arbor, MI 48106 - 1346 
THE DISPARITY OF PRINCIPAL ACCOUNTABILITY

\section{KATHRYN TAYLOR}

DISSERTATION APPROVED:

\begin{tabular}{ll}
\hline Date & Elizabeth Lugg, Chair \\
\hline Date & Joseph Pacha \\
\hline Date & Neil Sappington \\
\hline Date & Andrew Wise'
\end{tabular}




\title{
THE DISPARITY OF PRINCIPAL ACCOUNTABILITY
}

\author{
M. Kathryn Taylor
}

169 Pages

May 2011

This study begins with a review of court cases that have helped shape public education in America. Following the review is an analysis of federal reform in education from 1965 to the present, paired with educational leadership literature to highlight a disparity in what federal mandates and state policies have in place for accountability measures. The study ends with a state analysis of Illinois and Iowa to find the strengths and weaknesses of state policy in the area of principal accountability.

As policymakers have worked to increase accountability in K-12 education, efforts have focused on a variety of measures to both increase student achievement and close the achievement gap between advantaged and disadvantaged students. In education, little attention is given in state policies and federal reform efforts to what scholars in the field claim to be effective leadership models. The principal as instructional leader must be held accountable to effectively evaluate teachers to positively affect student achievement. In the analysis of Illinois and Iowa state policy, the researcher finds both to be weak in policies for principal accountability in effectively evaluating teachers to affect student achievement.

Due to this analysis of state policy, the researcher recommends policy provisions for the state of Illinois to better hold principals accountable in the evaluation of teachers 
to affect student achievement. These recommendations include a focus on what the state of Rhode Island is beginning to implement for principal accountability. 


\section{ACKNOWLEDGMENTS}

What an incredibly unique experience. There are so many individuals responsible for getting me through this journey. I would like to take a moment to acknowledge those individuals who walked along side me in the completion of this dissertation. I must begin with my advisor and chair, Dr. Elizabeth Lugg. Her passion of the law and her dedication to her students is what planted the seed in my mind on this educational reform topic. Her guidance in coursework and throughout this writing journey has been immeasurable. Dr. Joe Pacha's dedication with effective teacher evaluation was contagious. His experience and knowledge in this area shaped the passion I now have for the evaluation process. His attention to detail and informative feedback was greatly appreciated. Dr. Neil Sappington's knowledge and dedication to high quality curriculum and instruction helped mold my philosophy on instructional leadership. His feedback on the importance of principals understanding what good instruction looks like was critical. Dr. Andrew Wise was a dissertation saver! Thank you for agreeing to join this committee and for your professional guidance and commitment to provide me with crucial feedback.

This entire process could not have been possible without the tremendous support and guidance of dear friends and colleagues. To Dr. Robert Dean for his continued support in life-long learning and his weekly encouragement to "get that thing done!" To the faculty, staff, and parents of Thomas Metcalf Lab school who routinely encouraged me through the gentle inquiries about how my "writing was going." To my personal 
friends who stuck by my side and continued to keep me involved when I couldn't justify socializing. Thank you for your listening ears, gentle reminders, and positive push. To my amazing colleague Debbie Frank for guiding me, keeping me on my toes, supporting me, encouraging me, and most of all-listening to me vent about this journey. I will always be grateful for your amazing support at work and as a friend. To Kristi Sanders, Andrea Markert, and Cathy Weber for staying positive and reminding me how very close I was getting to achieving my goal. Your friendship and professional guidance were a source of comfort. Finally, to my dear friend, colleague, and mentor Dr. Amy Fritson Coffman. You are an amazing individual! Watching you along this same journey a few years ago inspired me to continue on mine. You kept me going when I didn't feel I could. You gave me the tools in my personal and professional life that allowed me to push through this journey.

To Pat McCarney, my formatter. I owe you a debt of gratitude for your work with me in the final stages of this dissertation. Thank you for your speediness and your push to get information to you. Your knowledge, skill, attention to detail, and ability to work with me to clarify my writing is much appreciated.

My acknowledgments would not be complete without my biggest cheerleadersmy family. To my parents who not only raised me to work hard but exhibited exactly what hard work entailed. Their ability, commitment, and inner drive in every aspect of their life (ALWAYS with integrity and high character) are what laid the foundation for me to reach success. For my brothers, sister, in-laws, nephews, and nieces who encouraged and supported me, not only through this process, but in all avenues of my life. To my niece Alli: What would I have done without you here at ISU this year? Your 
willingness to help out in so many ways is appreciated more than you may ever know. Thank you to all of you-Mom, Dad, Tom, Fran, Patrick, Alli, Phil, Kim, Ann, Chris, David, Mel, Joe, and Karla - for trying to understand the process I have been undertaking and for allowing me to take much needed breaks to come visit, play with my nieces and nephews, vent about my writing when I'm sure the topic was of no interest to you, and reminding me that I could do it! Your support, whether silent or not, was invaluable to me. I love you all more than words can say. You mean the world to me and I am ecstatic to no longer use the words, "I can't. I need to write." Thank you for your love and support!

M. K. T. 


\section{CONTENTS}

\section{Page}

ACKNOWLEDGMENTS

CONTENTS iv

TABLES viii

\section{CHAPTER}

I. INTRODUCTION 1

Statement of the Problem $\quad 4$

Purpose of the Study $\quad 5$

Research Questions $\quad 5$

II. REVIEW OF STATUTORY LITERATURE 6

Landmark United States Supreme Court Cases That Shaped Education $\quad 6$

Plessy v. Ferguson (1896) 6

Brown v. Board of Education (1954) 8

Milliken v. Bradley (1974) 11

Pennhurst et al. v. Halderman et al. (1981) 12

Zelman v. Simmons-Harris (2002) 14

A Review of Educational Reforms in the United States 17

$\begin{array}{ll}\text { Early America } & 17\end{array}$

Industrialism and the Common School Movement $\quad 18$

The Progressive and Measurement Movements $\quad 19$

Federal and National Interest $\quad 20$

General and Ongoing Funding for Education 22

The 1960s 24

The 1970s 27

The 1980s $\quad 29$

National Commission on Excellence $\quad 30$

Response to A Nation At Risk 33

iv 
Increased accountability 34

Student achievement measures $\quad 34$

Additional accountability measures $\quad 35$

The 1990s 36

Business-style accountability 36

From excellence to restructuring $\quad 38$

America 2000

Systemic reform 49

Reauthorization of ESEA 51

The Twenty-First Century 56

No Child Left Behind 56

IDEA reauthorization of $2004 \quad 62$

2008 to the present 63

Blueprint guidelines $\quad 64$

Race to the Top $\quad 68$

A Selection of State Court Cases on Teacher Evaluation $\quad 75$

Importance of Evaluation Documentation $\quad 75$

Principal Error $\quad 76$

Principal Professional Judgment $\quad 76$

Determining Tenure $\quad 78$

$\begin{array}{ll}\text { Understanding Legalities } & 79\end{array}$

$\begin{array}{lr}\text { Conclusions } & 80\end{array}$

III. REVIEW OF SCHOLARLY LITERATURE 82

Principal as Instructional Leader $\quad 82$

Leadership Styles $\quad 82$

Instructional leadership $\quad 84$

Accountability with curriculum and instruction $\quad 85$

Accountability in the evaluation of teachers $\quad 87$

Accountability in teacher tenure decisions $\quad 89$

Accountability in student achievement 91

Data analysis $\quad 91$

Setting goals 93

Teacher and School Level Factors $\quad 93$

$\begin{array}{ll}\text { Conclusion } & 95\end{array}$ 
Legal Research $\quad 96$

Document Analysis $\quad 97$

Pubic Analysis $\quad 98$

Quantitative Analysis $\quad 100$

$\begin{array}{ll}\text { V. RESULTS AND ANALYSIS } & 101\end{array}$

$\begin{array}{ll}\text { State Policies } & 101\end{array}$

Illinois Policy 101

$\begin{array}{lr}\text { Continued Contractual Service } & 103\end{array}$

Probationary period 103

Dismissal 103

Evaluation Code 105

2010-2011 Policy Amendments 108

Monitoring Programs 109

$\begin{array}{ll}\text { Accountability } & 110\end{array}$

$\begin{array}{ll}\text { Iowa Policy } & 112\end{array}$

Path to Continued Contractual Service 112

Teacher Evaluation and Principal Accountability 113

Evaluation Code 113

Career Path 114

Administrator Training 115

Iowa Leadership Academy 116

Principal evaluation and accountability 116

Overall State Policy Strengths and Weaknesses 119

National Council on Teacher Quality (NCTQ) Report 120

2010 State Policy Updates 121

Additional State Comparisons $\quad 123$

$\begin{array}{ll}\text { Student Achievement Results } & 124\end{array}$

Chance-for-Success 124

K-12 Achievement 125

Illinois and Iowa State Achievement Test Results 129 
School Improvements

VI. SUMMARY, CONCLUSIONS, AND RECOMMENDATIONS 136

Purpose of Study

136

Research Questions

136

Findings

136

Significance of Findings

138

Recommendations

145

Future Research

149

Conclusion

REFERENCES 


\section{TABLES}

Table

Page

$\begin{array}{ll}\text { 1. Federal Reform Efforts } & 70\end{array}$

2. 2009 NCTQ State Teacher Policy Yearbook Grades 120

3. Results from 2008 Quality Counts 126

4. Results from 2011 Quality Counts 126

5. Illinois and Iowa NAEP Results 128

6. Individual State Test Results from State Report Cards for 2002 to $2010 \quad 130$

7. Percent of Fourth, Eighth, and Eleventh Graders Scoring Proficient on ISTBS or ISTED

8. Percentage of Items Intended vs. Actually Required Higher Order Cognition

9. State and NAEP Comparison 


\section{CHAPTER I}

\section{INTRODUCTION}

The framework for the operation of public schools in the United States of America is found within the Constitution of the United States, state constitutions, and individual statutory laws. The Tenth Amendment to the Constitution states, "The powers not delegated to the United States by the Constitution, nor prohibited by it to the States, are reserved to the States respectively, or to the people" (U.S. Const. amend. X). The legal authority to operate public schools, therefore, resides with the individual state legislatures. Within each state's legal codes exist legal parameters for school districts, school boards, and employees. All school district policies and state constitutions are subordinate to the United States Constitution.

The amendments to the U.S. Constitution that directly affect the operation of public schools include the

- First Amendment, which provides rights to freedom of speech, freedom of press, and freedom of religion;

- Fourth Amendment, which provides protection from unreasonable searches and seizures;

- Fifth Amendment, which is reinforced by the Fourteenth Amendment and guarantees that an individual shall not be deprived of life, liberty, or property without due process of law;

- Eighth Amendment, which provides protection against cruel and unusual punishment; and

- Fourteenth Amendment, which guarantees under the equal protection clause both substantive and procedural due process (U.S. Const. amend. I, IV, V, VIII, \& XIV). 
"These amendments to the U.S. Constitution impact school officials in their management of schools by requiring that their decisions and actions regarding students and school personnel are consistent with constitutional requirements" (Essex, 2009, p. 3).

In addition to the U.S. Constitution and state constitutions are federal and state educational reform initiatives. Educational reform is the effort to improve the qualities, methods, and purposes of public schooling in America (Friedman, 2004). Though $A$ Nation at Risk (1983) is often considered the driving policy that began the continual path for educational reform, the topic of reform can be traced back to the "inception of public schools, which preceded the founding of the nation by almost 150 years" (Friedman, 2004, p. 4). One example is the systematic teacher training manual proposed in 1511 by Dutch humanist Desiderius Erasmus, titled Upon the Method of Right Instruction. The turn of the $20^{\text {th }}$ century brought about the configuration of the public education system known today, but not without some twists and turns. In the early $20^{\text {th }}$ century, the education of many did not go beyond eighth grade. Districts with high schools were not universal.

From 1918 to the end of the 1950 s, public education began to evolve into a more structured system with similarities among many, if not all, states. Some of the notable structural components were compulsory education laws, the creation of a national teachers exam, and the abolishment of segregation with the Supreme Court's decision in Brown v. Board of Education. Calls for accountability and a national debate about quality instruction and curriculum arose upon the publication of Rudolph Flesch's Why Johnny Can't Read. A rise in federal categorical aid, such as the National Defense Education Act, which increased funding for math, science, and foreign language 
curricula, also increased the federal government's role in elementary and secondary education (Friedman, 2004).

Scholars in the field of education have long discussed the role of the school leader, the principal. The responsibility of the principal is to be the instructional leader for the school (Edmonds, 1979; Marzano, 2003, Waters, Marzano, \& McNulty, 2003). In being the instructional leader, the principal must have knowledge of the curriculum and instruction (Fullan, 2001 \& 2002; Portin et al., 2003; Blasé \& Blasé, 2009). By attending professional development and engaging in conversations with teachers in the areas of curriculum and instruction, principals can continually increase their knowledge of effective practices (Cotton, 2003). Principals must work with teachers to build a positive climate that encourages the collaboration needed for a truly effective teacher evaluation process. Researchers believe an important focal point for principals is the evaluation process to determine the granting of tenure (Darling-Hammond, 2003; Strong \& Tucker, 2003; Hoerr, 2005; Danielson, 2008; Strong et al., 2008). The decision to grant teacher tenure plays a large role in teacher quality and overall student achievement. Principals work indirectly with students by providing professional development to teachers and analyzing data to increase student achievement (Darling-Hammond, 1995; Newmann, 2000; Fink \& Resnick, 2001; Leithwood et al., 2004). Principals must be held accountable to incorporate the strategies necessary to be an effective instructional leader (Waters, Marzano, \& McNulty, 2003).

Though information on the legal, legislative, and policy components of teacher accountability in the PreK-12 educational system can be found in educational reforms as well as in federal and state legislation, the accountability of PreK-12 principals seems to 
be missing. Are PreK-12 principals being held accountable in current educational reforms to serve as instructional leaders for teachers? Through use of the methodologies of legal research, document analysis, and policy analysis, a sampling of state laws and policies pertaining to public PreK-12 education was compared to determine whether PreK-12 principals are held accountable as instructional leaders in the evaluation process used to determine the granting of teacher tenure. This analysis was then applied to existing laws and policies in the state of Illinois to develop ideas and recommendations for possible methods of enhancing principal accountability in Illinois.

\section{Statement of the Problem}

Over the past 45 years, improvement in education in the United States has been working on two tracks. On the one track scholars and researchers have been working in the area of educational leadership, developing new and innovative theories. These theories have included how to lead educational institutions and obtain high achievement from both students and teachers. On the other track policy makers and legislatures have been working developing and instituting various school reforms. However, after a historic survey of both leadership literature and educational reform, and an analysis of how U.S. Supreme Court cases and individual state cases impact decisions and shape practice in the educational system, it appears that the two tracks have not intersected. That is to say, that few of the educational reform movements, until No Child Left Behind, incorporated a component focused on leadership and administrator accountability. In an effort to show a historical disparity in and need for principal accountability in educational reform efforts, I begin with a literature review of landmark U.S. Supreme Court cases that shaped the American public education system and continue with a brief historic look 
at federal education reform from 1965 to the present. I bring in individual state court cases that have had an impact on educational decisions for public school and conclude with scholarly research on the role of the principal as instructional leader.

\section{Purpose of the Study}

The purpose of the study was to review school reform in the U.S and to compare two selected states, Illinois and Iowa, to identify the strengths and weaknesses of policies governing principal accountability in teacher evaluation and its relationship to student achievement.

\section{Research Questions}

1. What is the history (from 1965-2010) of federal school reform that holds principals accountable in teacher evaluation as it relates to student achievement?

2. What are the current educational leadership models that hold principals accountable for student achievement?

3. When comparing two selected states (lowa and Illinois), what are the strengths and weaknesses of policies and rules governing principal accountability in teacher evaluation as it affects student achievement?

4. What policy recommendations from the two-state analysis can be made to improve the role of the principal as the instructional leader for the benefit of increasing student achievement? 


\section{CHAPTER II}

\section{REVIEW OF STATUTORY LITERATURE}

\section{Landmark United States Supreme Court Cases}

\section{That Shaped Education}

Landmark United States Supreme Court decisions have changed policies and practices in public education across America. These landmark cases involved increased educational opportunities with regard to racial segregation, educational placement, and treatment of children with disabilities and the creation of public school vouchers.

\section{Plessy v. Ferguson (1896)}

The United States Supreme Court's influence on public education began in 1896 with the landmark decision in Plessy v. Ferguson. In 1890, the state of Louisiana passed legislation entitled An Act to Promote the Comfort of Passengers, which provided for the separation of blacks and whites in all railway companies carrying passengers throughout the state of Louisiana. In a personal challenge to the Louisiana railway regulations separating whites and blacks on the state train, Homer Plessy, who claimed to be $7 / 8$ Caucasian and 1/8 African blood, bought a ticket on the Louisiana railway and proceeded to sit in the coach designated for white people. Knowing this was a planned challenge to the railway regulations, the railway employees approached Plessy and told him to move to the coach designated for black people. Plessy refused and was forcibly removed from the white people's coach. He was then arrested, and upon release he filed suit against the 
Louisiana railway, claiming the law was unconstitutional. Upon the decision from the lower court for the state of Louisiana, Plessy filed a writ of error. The Louisiana State Supreme Court upheld the lower court's verdict and denied a request for a writ of prohibition. The United States Supreme Court then heard this case, affirming the decision of the lower courts on the basis that separate but equal accommodations for both whites and blacks were provided on the train. The U.S. Supreme Court held that Louisiana was not in violation of either the Thirteenth or Fourteenth Amendment. Justice Brown delivered the opinion of the court with the holding rationale that under the 1890 General Assembly Act of the State of Louisiana/Separate Car Act, the Thirteenth and Fourteenth Amendments to the U.S. Constitution were not violated. Separate but equal accommodations were permitted for whites and colored races. In regard to the Thirteenth Amendment, "A statute which implies merely a legal distinction between the white and colored races...has no tendency to destroy the legal equality of the two races" (No. 210, Lexis Nexis 339, p. 3). In regard to the Fourteenth Amendment, Justice Brown's rationale was based on the question of reasonableness of the regulation.

In determining the question of reasonableness it is at liberty to act with reference to the established usages, customs and traditions of the people, and with a view to the promotion of their comfort, and the preservation of the public peace and good order. (No. 210, Lexis Nexis 3390, p. 2)

Chief Justice Brown furthered the court's holding rationale in stating that nothing in the legislation said the colored race was of inferior status, and therefore, if separate but equal accommodations were provided, all rights were secured.

The U.S. Supreme Court decision in this segregation case set the precedent for future court decisions, transferring into education. The U.S. Supreme Court used the 
Plessy v. Ferguson court case rationale in Cumming v. Richmond County Board of Education (1899), where a black high school was discontinued and the students were advised to seek education in a religious-affiliated school due to the need for additional facilities for black elementary-level students. The court furthered the rationale that the matter of education and its conduct was solely a state concern. In the 1908 U.S. Supreme Court decision of Berea College v. Kentucky, the court held that a state law could forbid the instruction of both white and black races at the same time to counter a Kentucky law which prohibited any school or organization from teaching black and white students in the same school and at the same time. The law was intended to stop the racially integrated schooling at Madison County's Berea College. The court held that the only way white and black students could be educated at the same time was if the classes were conducted at least 25 miles apart. These court cases established that states could maintain separate educational facilities and systems for blacks and whites, and that the state arm could extend these regulations into private schools as well.

\section{Brown v. Board of Education (1954)}

The ruling in Plessy v. Ferguson was referenced in the pivotal court decision of Brown v. Board of Education of Topeka, Kansas (1954). In the 1940s and 1950s, the National Association for the Advancement of Colored People (NAACP) began challenging the doctrine of separate but equal brought on by Plessy v. Ferguson. Linda Brown, a student in Topeka, Kansas, was denied access to the white school close to her home and forced to travel to a school for black students 21 miles away. The NAACP and the chief legal counselor, Thurgood Marshall, supported a group of African-American minors by challenging the decision in the District Court of Kansas, finding that segre- 
gated schools did not violate the Fourteenth Amendment. The district court upheld the decision in Plessy v. Ferguson that separate but equal facilities were allowed. Using the Brown case and similar cases in four other states, Marshall brought this case to the U.S. Supreme Court on the basis that the Fourteenth Amendment should be corrected. He argued that the "history of the Fourteenth Amendment is inconclusive as to its intended effect on public education" (No. 1, Lexis Nexis 2094, p. 4). In each of the individual cases, the black children were denied access to the public schools attended by only white children. Although individual state laws permitted segregation by race, the plaintiffs argued that even though facilities were to be separate but equal, this "deprived the children of the minority group of equal educational opportunities" (No. 1, Lexis Nexis 2094, p. 4). The Topeka Board of Education maintained that the intention of the Fourteenth Amendment was not to abolish segregation, and that the tradition of state rights should be upheld with regard to the segregation of public schools. The question for the court to decide was whether segregation of children in public schools solely on the basis of race deprived the minority children of equal educational opportunities, even if the facilities and materials were equal (Alexander, 2008).

In this 1950s landmark case, the U.S. Supreme Court found that the individual states violated the establishment clause of the Fourteenth Amendment. The court overturned Plessy v. Ferguson and the doctrine of separate but equal. Chief Justice Warren delivered the unanimous opinion of the court with the holding rationale that in all four individual state cases (Kansas, South Carolina, Virginia, and Delaware), the black children were deprived of the "equal protection of the laws under the Fourteenth Amendment" (No. 1, Lexis Nexis 2094, p. 3). Chief Justice Warren's rationale spanned 
the history of public education and the time period and social constraints when the Fourteenth Amendment was created. He included the history of how public schooling in the north had advanced further with the common school movement than in the south during the creation of the Fourteenth Amendment. He used this rationale to explain why he was now overruling the decision in Plessy v. Ferguson-that the time period and social constraints involved in that decision are much different than the time period and social constraints in 1950 . Chief Justice Warren explained the court's opinion further by stating that the court must examine the place public education holds in the present time across the nation in American life, not the place it held during Plessy v. Ferguson. The decision was based on the effect segregation itself had on public education for all children. Even if facilities were deemed equal, the court maintained that separate facilities deprived children in the minority group of equal educational opportunities. The doctrine of separate but equal had no place in educational facilities. Segregation was a "denial of the equal protection of the laws" (No. 1, Lexis Nexis 2094, p. 10). Therefore, the court decreed that separation was inherently unequal and unconstitutional (Alexander, 2008).

Brown v. Board of Education was a landmark case in the desegregation of public schools across the nation. No longer could there be separate schools for whites and blacks. All public schools across the nation had to educate whites and blacks together. Separate but equal was deemed unconstitutional. This case opened future court pursuits in education reform across America (Friedman, 2004). In addition to desegregating schools based on race, Brown v. Board of Education was referenced in future litigation about school finance, primarily the overall state efforts to equalize funding across school districts. 


\section{Milliken v. Bradley (1974)}

Discussion of segregation in public schools was not dismissed in the courts after Brown v. Board of Education. In 1974, Detroit schoolchildren and parents brought a case against Governor Milliken and the Detroit City Board of Education, seeking desegregation of the city's public schools. In Milliken v. Bradley (1974), the children and parents claimed segregation of the city's public schools primarily due to the way district lines and attendance zone boundaries were drawn. The students and parents also claimed these lines were drawn out of political convenience and not geographic formality. The district court ruled in favor of the children and parents, stating that in order to desegregate the Detroit public schools, it was necessary to look beyond the defined district lines and develop a plan that included the surrounding suburban school districts. Due to what people called "white flight," where white families left the inner city and moved to the surrounding area, the city had become primarily black. The lower court found the district had engaged in unconstitutional acts, resulting in de jure segregation for the city of Detroit. In an appeal to the United States Court of Appeals, the decision of the lower court was affirmed in terms of de jure segregation. On writ of certiorari, the case was brought to the United States Supreme Court. The U.S. Supreme Court reversed the decision of the lower courts with a 5-4 vote and "remanded for formulation of a decree restricted to the city of Detroit" (No. 73-434, Lexis Nexis 94, p. 4).

The court's decision held that the federal government could not impose a multidistrict solution to a single district de jure segregation problem unless it was proven that the surrounding school districts had imposed racially discriminatory acts (white flight) that caused the interdistrict segregation, or that district lines and attendance zones had 
been drawn on the basis of race. In this case, the record of de jure segregation was in the city of Detroit schools only and did not establish constitutional violations by the surrounding school districts. To force surrounding school districts to reorganize for a racial balance within the city of Detroit schools would give rise to transportation, administration, and financial burdens. The Supreme Court held that the demand for the outlying school districts was impermissible and not justified based on Brown v. Board of Education. In this case, the court emphasized local control over public schools (No. 73434, Lexis Nexis 94).

Milliken v. Bradley clearly defined the substantive right to school segregation. "The practicability of a metropolitan desegregation plan was irrelevant in the constitutional equation" (No. 73-434, Lexis Nexis 94, p. 1696). It could be argued that Milliken v. Bradley helped to cause a racial dissention between urban and suburban school districts. This case brought about the concept of white flight from the cities to the suburbs, causing city schools to remain predominately black. It could also be suggested that due to the decision of Milliken v. Bradley more financial aid for equipment and supplies was given to urban school districts, which might not have been otherwise available (Alexander, 2008).

\section{Pennhurst et al. v. Halderman et al. (1981)}

Until the 1980s, landmark Supreme Court cases dealt with racial segregation. In 1980, Pennhurst State School and Hospital et al. v. Halderman et al. (1981) brought attention to the educational placement and treatment of children with disabilities. In Pennhurst State School and Hospital v. Halderman, a mentally retarded resident of the Pennhurst State School filed suit against the school for inhumane treatment of all 
residents. The suit claimed the rights of the residents had been violated under the Eighth and Fourteenth Amendments, the Developmentally Disabled Assistance and Bill of Rights Act of (1970), and the Pennsylvania Mental Health and Retardation Act (MH/MR) of 1966 (No. 79-1404, Lexis Nexis, p. 1).

Prior to the case arriving at the United States Supreme Court, the district court ruled in favor of Halderman et al. on the basis that the conditions were not only dangerous but inadequate for "the habilitation of the retarded" (No. 79-1404, Lexis Nexis, p. 3). The court held that the conditions violated the

- due process clause of the MH/MR Act;

- freedom from harm provision of the Eighth Amendment, applied to states through the Fourteenth Amendment;

- equal protection clause; and

- Developmentally Disabled Assistance and Bill of Rights Act (1970).

In its decision, the district court held that the least restrictive environment should be provided. The hospital was ordered to close and the residents removed from the school and provided with other living arrangements. Pennhurst et al. appealed, claiming the Eleventh Amendment of the U.S. Constitution stated that federal court did not have jurisdiction to rule on state claims. The court of appeals agreed with the least restrictive environment claim from the district court, but did not order the closing of the hospital. The case was then taken to the U.S. Supreme Court on writ of certiorari on the contention that the Developmentally Disabled Assistance and Bill of Rights Act did not create "in favor of the mentally retarded any substantive rights to appropriate treatment in the least restrictive environment" (No. 79-1404, Lexis Nexis, p. 3). The petitioners questioned the 
authority of Congress to impose these obligations.

The U.S. Supreme Court reversed the decisions of the lower courts, expressing the opinion that 6010 of the Developmentally Disabled Assistance and Bill of Rights Act did not guarantee mentally retarded individuals with the "substantive rights to appropriate treatment in the least restrictive environment" (No. 79-1404, Lexis Nexis, p. 3). Justice Rehnquist delivered the opinion of the Supreme Court that referenced the general structure of the Developmentally Disabled Assistance and Bill of Rights Act and the congressional intent when this act was created. In its rationale, the court failed to recognize the "well-settled distinction between congressional 'encouragement' of state programs and the imposition of binding obligation on the States" (No. 79-1404, Lexis Nexis, p. 18). Pennhurst received no direct federal funds from this act and therefore could not be held to the specifications of the act. "Judgment could not be upheld against county officials on basis of their state law obligations where any relief granted against county officials alone on basis of state statute would be partial and incomplete at best" (Biers, n.d., para. 3).

The decision in this case upheld a tight restraint on the powers of federal courts over states. This decision established the precedent that if state law violated the federal constitution, then the state could not undermine the ruling. Control over public education and public education funds was left up to the discretion of the state, unless those federal funds used by the state specified categories in which funds were to be used (No. 79-1404, Lexis Nexis).

\section{Zelman v. Simmons-Harris (2002)}

With America's eye on public education, due in part to the No Child Left Behind Act of 2001, increased awareness of improvements to America's public schools was on 
the radar of policymakers. Zelman $v$. Simmons-Harris (2002) was the landmark decision on public school vouchers. In 1995, the state of Ohio took control of the Cleveland city public schools due to continued poor educational services for children. Cleveland public schools were among the worst-performing schools in the nation. Upon taking control of the city public schools, the state of Ohio created a pilot program titled the Ohio Pilot Scholarship Program to provide educational choices to families whose children resided in the Cleveland city public schools. The program provided two forms of assistance: either tuition aid for students to attend a private or public participating school of their parents' choice, or tutorial aid to remain enrolled in the city public schools. The program began in the 1996-1997 school year and by the 1999-2000 school year, 56 private schools were participating in the program. Of these private schools, 46 had a religious affiliation. Although the adjacent public schools were given the choice to participate, none of them chose to do so.

In 1996, the parent of a public school student challenged the Ohio Pilot Scholarship Program as a violation of the Ohio Constitution, as well as the establishment clause of the United States Constitution. The lower court found no violation to the state constitution or U.S. Constitution. Upon appeal, the Ohio Supreme Court reversed the lower court decision on the basis that the voucher program violated the "one subject" rule because it was an addition to the Ohio state budget bill (No. 79-1404, Lexis Nexis).

In response to the Ohio Supreme Court decision, the Ohio legislature brought back the voucher program in 1999, this time as a freestanding measure. Zelman-Harris and others challenged this program again, claiming a violation of the First Amendment's establishment clause. The federal district court ruled for the parents, claiming the 
voucher program was unconstitutional. The state appealed this decision in the Court of Appeals for the Sixth Circuit, but was denied. The state of Ohio then filed and was granted an appeal to the U.S. Supreme Court. The central legal issue in this appeal to the U.S. Supreme Court was the question of whether the First Amendment's establishment clause prohibited a voucher program in which participating students could attend schools with a religious affiliation.

On June 27, 2002, the U.S. Supreme Court ruled in a 5-4 decision that the program did not offend the First Amendment's establishment clause, specifically the religion clause. Chief Justice Rehnquist delivered the opinion of the court's rationale that the Ohio Pilot Scholarship Program was "enacted for the valid secular purpose of providing educational assistance to poor children in a demonstrably failing public school system" and that the program was of "true private choice that did not have the effect of advancing religion" (No. 79-1404, Lexis Nexis, p. 4). He furthered the holding rationale that the program permitted the participation of all schools — public and private, religious and nonreligious - as well as public schools adjacent to the city of Cleveland. The court held that the program did not endorse religious practices and beliefs and there was no evidence that the program failed to provide opportunities for parents to select secular or nonsecular educational options. The fact that more private schools chose to participate in this voucher program and that $96 \%$ of scholarship recipients chose to enroll in religious schools did not prove that nonreligious schools were discouraged from participating (No. 79-1404, Lexis Nexis).

"Cleveland's preponderance of religiously affiliated schools did not result from the program, but is a phenomenon common to many American cities" (No. 79-1404, 
Lexis Nexis, p. 8). The impact of this court decision was the ability to expand voucher programs among all state public schools. This court case affirmed previous court case decisions that states may enact programs allowing parents to use public funds for religious or nonreligious educational improvement (North Carolina Department of Administration, n.d.).

Just as landmark U.S. Supreme Court decisions changed policies and practices in public education, legislatures and policymakers have implemented federal education reform measures in an attempt to provide increased educational opportunities for all children in America.

\section{A Review of Educational Reforms in the United States}

\section{Early America}

Educational reform dates back to antiquity. In 360 B.C. when Plato wrote The Republic, he discussed the benefits of a state-supported educational system. In the first century A.D. Quintilian, a Roman educator, brought in the benefits of a broad public education system (Friedman, 2004). Early education in America began with the influence of the English settlers in North America. Colonial government allowed both individuals and religious groups to establish schools independently. The colonial government allowed this early separation of church and state due to the large number of religious denominations vested in the teaching of religious principles in schools (Friedman, 2004). Along with religious differences, the colonial regions had social and economic differences. The government kept a far distance from public education until 1642, when the passage of the Massachusetts Act occurred. This act stated that parents and "masters" were responsible for the basic education and literacy of children, and 
should these parents and masters not meet the educational responsibility, then the government had the right to remove the children from that home and place them where they would receive adequate instruction (Holland, 1855). Massachusetts followed with the Massachusetts Law of 1647 , requiring towns of 50 or more families to establish elementary schools and towns of 100 or more to establish secondary schools. These two laws initiated governmental involvement in public education and were the forerunners for the future state of public schooling in America (Friedman, 2004, p. 8).

Thomas Jefferson supported the expansion of education in his 1778 Virginia legislative proposal A Bill for the More General Diffusion of Knowledge. This bill presented Jefferson's argument for the education of all, not just the privileged. State governments continued to be vested in education, led by the adoption of the Pennsylvania Constitution in 1776 , which heralded a greater state control in public education (United Nations Educational, 1987). In the Pennsylvania Constitution, lawmakers required that the state pay for public school teachers' salaries. Pennsylvania set this constitutional precedent, and by the beginning of the $19^{\text {th }}$ century most states had set up provisions for public schools in state constitutions.

\section{Industrialism and the Common School Movement}

Public education grew in the $19^{\text {th }}$ century with the rise of industrialization. During this time, children were part of the workforce; however, industrialization required training. In an 1819 effort, though unsuccessful in the Kentucky legislature, the governor proposed the creation of a common school system. In his request, he stressed the importance of providing education for all, from the wealthy to the poor: 
Education is more vitally important in a republic than in any other form of government; for there the right to administer the common to all, and when they have the opportunity of administering the government, the means of obtaining the wisdom requisite for its administration should be accessible to all. (Alexander, 2005, p. 26)

By the mid-1800s, states had established educational systems as common schools. A leader in the common school education movement was Horace Mann. Mann, a Massachusetts legislator, led the development of a state board of education and became the board's first secretary after its creation. Mann successfully increased student attendance in the common schools, established 50 high schools, attained state tax to support teacher salaries and new school buildings, and created three normal schools in the country (Friedman, 2004). Normal schools primarily functioned to provide an educational setting for the focus of teacher training and preparation (Board of Education of the State of Illinois, 1870). In 1857, Governor William Bissell of Illinois signed a bill to create a normal school and a board of education for the state of Illinois (Illinois State University, 2007). Jesse Fell took up the plea and Illinois State Normal University became the first state university in Illinois assigned with the mission to provide training to teachers. These events, along with the appointment of a local superintendent in Buffalo, New York, whose primary responsibility was to develop a "uniform course of study" (Friedman, 2004, p. 103), increased support for the involvement of government in public education.

\section{The Progressive and Measurement Movements}

The turn of the $20^{\text {th }}$ century brought about the configuration of the public education system, recognizable with the emergence of the progressive movement in education. By 1900 , more than 300 normal schools designed to train teachers were in 
existence. The progressive education movement's goals included practical instruction in schools, with modern teaching methods, which recognized that all students learn in different ways (Berube, 1995). The leading spokesman in the progressive education movement was John Dewey, an advocate for child-centered education. He believed children should experience education through observation and hands-on learning and viewed the education of a child as a lifelong process, connecting academic instruction with the social, emotional, and physical needs of the child (Berube, 1995). In 1894, John Dewey began testing his educational theories when he accepted a position as the chairman of the Department of Philosophy, Psychology, and Pedagogy at the University of Chicago in Illinois and established the University Elementary School as a research and demonstration center for the Department of Pedagogy. This would later become the University of Chicago Laboratory School (Westbrook, 1991).

While the progressive education movement was evolving, the measurement movement in education began. The measurement movement focused on an increased use and application of intelligence and aptitude tests (Berube, 1995). These tests initiated the push for intelligence and standardized testing which would continue in public education. Designed from military testing procedures, these tests allowed schools to both classify and compare students, as well as to diagnose learning difficulties in a relatively easy and inexpensive manner (Friedman, 2004).

\section{Federal and National Interest}

With the expanded public's interest in education came a stronger desire for the federal government to promote public interest in education. To help promote and support public initiatives in education, Congress passed the first federal categorical aid legislation 
in 1917. The Smith-Hughes Act provided federal aid to states that supported vocational education below the college level. This funding was categorized for teachers' salaries and teacher preparation in the area of vocational education. Perhaps a better-known example of federal categorical aid legislation came after the Union of Soviet Socialist Republics' (USSR) launch of Sputnik. President Eisenhower signed the National Defense Education Act into law, providing federal funding to school districts that increased and enhanced education in the areas of math, science, and foreign language.

The 1920s brought attention to the idea of creating curricula in public schools to support progressive educational theory (Berube, 1995). Progressive education intended to describe the practice of making public schools more effective in two primary areas: respect for the diversity of all children and the ability to develop a critical, sociallyengaged intelligence in children (University of Vermont, 2002). This signaled the movement of educational influence toward curriculum specialists and away from parents and teachers (Friedman, 2004). Led by John Dewey, the progressive education movement of the 1920 s sought to educate the whole child. Education of the whole child included the academic, physical, social, and emotional development of children. Following this belief, in the 1930s the Progressive Education Association began an 8-year study to demonstrate that the academic requirements other groups stressed as important were unnecessary for college admission. As the 1930 s came to an end, greater emphasis was placed on teacher training and certification, initiated by the creation and administration of the national teachers' examination. This certification exam assessed knowledge in content areas, teaching methods, and educational history. 
In the 1950s, Rudolph Flesch's Why Johnny Can't Read created a national debate about literacy instruction and the common teaching practices occurring in public schools. Flesch argued that phonics was the best way to teach children to read, rather than relying on sight word reading. This sparked further discussion on the best strategies for reading instruction, with accountability remaining in the competency of teachers.

Until A Nation at Risk (1983), the federal government's role in public education had been one of indirect support. "Never directly controlling education, but generally in a positive and affirmative manner, the Congress has, from time to time, fashioned educational policy to address certain perceived national interests" (Alexander, 2005, p. 65).

\section{General and Ongoing Funding for Education}

Categorical aid is state or federal grant money intended to financially support or reimburse specific instructional programs and supporting programs, or to aid a specific group of students in a particular educational program (U.S. Department of Education, 2008). The U.S. federal government provides this aid to individual states. State funding is the decision of individual states and is defined by the state's constitution, statutes, and regulations.

Although the Smith-Hughes Act of 1917 began categorical aid for schools below the college level, categorical aid was first initiated with the passing of the Morrill Act in 1862 to benefit higher education. The Morrill Act provided a grant of land to each state in which the land was to be sold, with the proceeds delegated for the creation, maintenance, and support of at least one college that focused instruction on agriculture and mechanical arts. Congress allowed individual states to decide how these proceeds would be delegated, based on the federal criteria. The passing of this land grant act was 
the initial step in the federal government's financial assistance for public education, gearing categorical aid toward a particular emphasis in public education.

With the creation of categorical grant programs, Congress defined the role of the federal government as one of "supplementary assistance" to state educational systems (Alexander, 2005, p. 65). Congress began to increase the federal government's role in public education with the creation of these federal categorical grant programs. If states accepted the federal funds, they were bound by the specified guidelines of those funds. Once states accepted the federal funds, the federal government had more control in guiding education within each state.

State and federal categorical aid is based on yearly legislation budget approval. Categorical aid is not divided equally among all districts within a state. Each fiscal year, individual states decide which programs receive what percentage of categorical aid funding using a multiplier to decide which school districts receive what portion, based on the identified need. Each state may be different. Typically, states consider instructional programs in the greatest need and seek to remedy inequities among students (EdSource, 1996-2010). Sometimes grant money is given to districts automatically, usually for programs the federal or state government has mandated. Other times, states require an application which specifies how the individual school district will use the grant money. "Categorical grants have a narrow range of eligible activities, permitting funds to be used only for specific, narrowly defined purposes. Funds may be distributed based on a formula, or at the discretion of agencies" (Library of Congress, 2002, p. 3).

The State Fiscal Stabilization Fund, a program that began in 2010 under the American Recovery and Reinvestment Act of 2009, was designed to provide one-time 
financial appropriations to states in order to help stabilize budgets across the nation (U.S. Department of Education, 2009). These funds were distributed directly to individual states in order to

- Help stabilize state and local government budgets in order to minimize and avoid reductions in education and other essential public services.

- Help ensure that local educational agencies (LEAs)... have the resources to avert cuts and retain educational personnel and staff.

- Help support the modernization, renovation, and repair of school and college facilities. (U.S. Department of Education, 2010, para. 2)

These categorical aid funds were earmarked for specific areas within each state's PreK-12 educational programs, focusing on the support of low-income schools, the improvement of special education programs, educational technology grants, vocational rehabilitation, independent living services, and McKinney-Vento homeless assistance (U.S. Department of Education, 2009).

\section{The 1960s}

The Civil Rights Act of 1964, specifically Title VI, provided federal financial assistance to public schools to support the U.S. Supreme Court decision of public school desegregation.

No person in the United States shall, on the ground of race, color, or national origin, be excluded from participation in, be denied the benefits of, or be subjected to discrimination under any program or activity receiving Federal financial assistance. (Civil Rights Act of 1964)

With Title VI, Congress "provided a statutory remedy against discrimination apart from and beyond equal protection" (Civil Rights Act of 1964). The impact of this act on public education was the ultimate denial of federal funds for those states that did not comply, a reoccurring theme in the federal government's continual encouragement of reformation in America's public schools by state and local educational agencies. 
President Lyndon B. Johnson's State of the Union speech declared a national war on poverty (U.S. Department of Education, 2009). In the midst of the civil rights movement, the Economic Opportunity Act of 1964 was enacted to improve the way students, especially those in poverty, were prepared for the skills necessary to successfully compete in the expanding economy. The Economic Opportunity Act entailed the creation of community programs such as Upward Bound, a program designed to help students from low-income families or families in which both parents were without bachelor's degrees to prepare for college entrance and beyond; and Project Head Start, a program designed to help disadvantaged preschool-aged children receive the skills necessary in the areas of education, health, nutrition, and social services in order to enter kindergarten at or close to the level of their non-disadvantaged peers. These programs were the first in a continuation of programs and policy reform initiatives designed to help disadvantaged Americans (Friedman, 2004).

The passage of the Elementary and Secondary Education Act (ESEA) of 1965 provided funding primarily for the education of culturally disadvantaged children. The enactment of this federal legislation set the precedent for future federal funding in K-12 education (Friedman, 2004). ESEA consisted of five major sections, called titles, which provided federal funding in the following manner:

- Title I provided local education agencies with funds to educate students from low-income families.

- Title II provided funding for school libraries and instructional materials.

- Title III provided funding for centers that offered supplemental education services.

- Title IV provided funding for research and training in education. 
- Title V provided funding to strengthen state departments of education. (ESEA, 1965)

Title I provided the most financial benefit to public schools with its focus on the area of disadvantaged children. These funds were to be used to benefit students who were not achieving well academically, or who were at risk of educational failure. Title I allowed for the expansion of the programs started with the Economic Opportunity Act of 1964, such as Project Head Start. Funds were allocated in the areas of bilingual program development, guidance and counseling programs, and reading instruction programs for students who met the above-mentioned criteria.

"The ESEA was the most far-reaching piece of federal education legislation in the history of the United Sates, providing more than $\$ 1$ billion in federal funds to education" (Friedman, 2004, p. 59). The ESEA program, including the Head Start program for early childhood development, was created to provide equal opportunity for all children in America's public education system (U.S. Department of Education, 2009). Though ESEA enhanced funding in public education, local school district control over educational expenditures lessened as state involvement in the use of these funds became increasingly controlled by federal funding criteria.

Public attention and scrutiny of education were fueled by published articles and books on what many were beginning to see as a less than adequate public school education in America. Jonathan Kozol, a teacher during the 1960s, published Death at an Early Age in 1967, which negatively described the Boston Public School System in regard to instructional conditions and teacher incompetence. The publication of this book reignited discussion on the state of American public education. In the initial enactment of 
ESEA, no mention of teacher evaluation or principal accountability and the affect on student achievement existed.

The 1970s

In 1970 an extension to the Elementary and Secondary Education Assistance Programs established grants to state and local educational agencies and brought about the creation of the National Commission on School Finance. State categorical aid earmarked for the creation of programs for students with disabilities began in a few states in the 1940s. These funds provided for the creation of programs but did not address the specific educational needs of children with disabilities. Two pivotal state Supreme Court cases helped gain more federal rights for students with disabilities in public education. In the case of Pennsylvania Assn. for Retarded Children (PARC) v. Commonwealth (1971) children with mental retardation sued the state of Pennsylvania, claiming they had been denied a public education. The claim detailed specific areas in which they felt their rights had been violated:

- Their due process rights were violated because they were excluded from public education and/or their educational programs had been changed without notice.

- The education provided to all other children by state law had been "arbitrarily and capriciously denied" to them.

- Their equal protection rights were violated because there was no basis to decide that children with mental retardation were uneducable or untrainable. (PARC v. Commonwealth, 1971)

In a court decree, the parties came to an agreement that the state of Pennsylvania was obligated to provide free, public education to all mentally retarded children in a manner appropriate to the individual child's ability level. This case was referenced and used as the basis in the 1972 Mills v. Board of Education of District of Columbia court decision. Mills v. Board of Education of District of Columbia emphasized the need for 
appropriate public services for children with disabilities. This civil action suit was brought on by seven children with disabilities in the District of Columbia public school system who sought to not be excluded or denied access to public education. The case dealt with the practice of suspending, expelling, and excluding children with special needs from the District of Columbia public schools. The court of the District of Columbia held that the city public schools did fail to provide education and training to students with disabilities and that due process rights were violated in the exclusion, suspension, expulsion, reassignment, or transfer of these students to other schools (Mills v. Board of Education of District of Columbia, 1972). Following landmark cases like PARC v. Commonwealth and Mills v. Board of Education of District of Columbia, which established the right for all handicapped children to be educated, the Education for All Handicapped Children Act (or All Handicapped Children Act of 1975), was enacted to provide free and appropriate public education designed to meet the needs of all handicapped children across the nation. This act provided federal funding to individual states for the identification and education of disabled children. The provisions of the act ensured

- a free and appropriate public education,

- an individualized education program,

- special education services and related services,

- due process procedures, and

- the least restrictive environment for learning. (Alexander, 2005, p. 491, and Education for All Handicapped Children Act, 1975)

The act was immediately put into place in 1975 , addressing first those children with disabilities who were not receiving any educational services, followed by the enhancement of services for children with disabilities who were being inadequately served in public schools. By September 1, 1978, all children with disabilities between the ages of 3 
and 18 were to be appropriately educated, and by September 1,1980 , the age increased to 21 (Education for All Handicapped Children Act, 1975). This act continued to be amended, and was renamed the Individuals with Disabilities Education Act (IDEA) in 1990. IDEA brought about the need to evaluate decisions on student programming and placement, but did not discuss the evaluation of teachers in these programs.

The 1970s ended with even more federal involvement in public education.

Although the Department of Education was created in 1867 to help states establish effective school systems (U.S. Department of Education, 2009), by the final year of the Carter administration, the Department of Education had become a cabinet-level agency. Department of Education legislation on the federal level continued to focus attention on public education. The goals of the 1980 cabinet-level Department of Education were to

- strengthen and streamline the federal-state political relationship by reducing the amount of "red tape" needed for federal programs,

- declare a focus on individual students and not educational interest groups,

- allow local educational control by not imposing strict federal regulations,

- encourage the establishment of local-level coalitions,

- identify local schools with established, successful programs as a model for other schools across the nation,

- provide equity in education, and

- be proactive instead of reactive to education and teacher roles in the classroom. (Alexander, 2005)

These goals focused on local control of programs and teacher expectations, but did not pertain to principal accountability in the evaluation of teachers. As President Carter's term ended, these identified goals of the Department of Education were basically unmet.

\section{The 1980s}

The 1980s brought in President Ronald Reagan's philosophy on public education: leave public education in the hands of state and local agencies, not the federal govern- 
ment. President Reagan was an adamant supporter of state and local control over public education. Reagan's administration focused early attention on reducing taxes and downsizing federal government involvement in education (Stallings, 2002, p. 4). Though Reagan was not successful in his desire to dismantle the Department of Education, categorical aid programs were either eliminated or combined into larger grants. The federal education budget was cut and the Department of Education staff was significantly reduced (Vinovskis, 2009).

In his efforts to reorganize the federal Department of Education, Reagan appointed Terrel H. Bell to succeed Shirley Hufstedler as Secretary of Education in 1981. Bell, a previous school superintendent, was given the responsibility of dismantling the Department of Education. Instead of dismantling the Department of Education, President Reagan and Secretary Bell worked to make budget cuts in several federal grant programs and decreased federal involvement in education (Bell, 1988).

National Commission on Excellence. In August 1981, Secretary Bell formed the National Commission on Excellence in Education (NCEE) as a cabinet-level operation. This 18 -member panel, crossing party lines, created the report that set policy reform of education in motion and began the excellence movement in education. In the historic report entitled $A$ Nation at Risk: The Imperative for Educational Reform (1983), the commission claimed the nation's educational system had failed to provide all children with equal opportunities to learn. The commission expressed concern for the quality of the intellectual, moral, and spiritual strengths of the American people, which were "being eroded by a rising tide of mediocrity that threatens our very future as a Nation and a people" (National Commission on Excellence, 1983, para. 2). This reform document 
....argued that the declines in education could be reversed. It recommended strengthening state and local high school graduation course requirements, establishing higher academic standards, requiring more student time to be spent in school, improving teacher preparation, and holding elected officials across the nation accountable for making necessary improvements. (Peterson, 2003, p. 16)

The report examined how our once unchallenged country risked being surpassed by worldly competitors in the areas of commerce, industry, science, and technological innovation (National Commission on Excellence, 1983). Schools and colleges were praised for their historical efforts but criticized for the evolving state of mediocrity that had become a part of public education. In testimony received by the NCEE, the identified education risks included

- an international comparison of student achievement showing that America rated last in seven areas, and never rated in the top one or two in any area;

- approximately 23 million American adults were functionally illiterate;

- approximately $40 \%$ of minority youth identified as functionally illiterate;

- over half of the students identified as gifted in public schools did not match this identification in tested ability;

- average scores on the College Board's Scholastic Aptitude Tests (SAT) declined between 1963 and 1980 by an average of over 50 points in verbal scores and 40 points in math scores;

- a steady decline since 1969 in national assessments of science achievement for 17-year-olds; and

- business and military leader complaints concerning a continual need to provide costly remedial programs in reading, writing, spelling, and computation. (National Commission on Excellence, 1983)

This report claimed these educational deficiencies came at a time when the need for highskilled workers was accelerating rapidly and growing dependence on technology was transforming most occupations (National Commission on Excellence, 1983). Stating that tension lied between the hope for education and the frustration characterizing American attitudes about education, the commission reported that the interviews conducted found hope evident in the commitment of students, parents, teachers, and school board 
members, but behind this hope existed a national sense of frustration that was "dimming of personal expectations and the fear of losing a shared vision for America" (National Commission on Excellence, 1983, para. 18). The commission concluded that the frustration of the American public had significant political implications. This frustration cut across all ages, races, socioeconomic statuses, and political groups, forcing a commitment among political and educational leaders to begin the work necessary for excellence in education. The commission defined "excellence" at the level of the individual learner and the level of the school or college. Excellence for the individual learner was defined as performing in ways that test personal limits. For schools and colleges, excellence was defined as setting high expectations and goals for all learners and finding ways to help all students reach these goals and expectations.

Our goal must be to develop the talents of all to their fullest. Attaining that goal requires that we expect and assist all students to work to the limits of their capabilities. We should expect schools to have genuinely high standards rather than minimum ones, and parents to support and encourage their children to make the most of their talents and abilities. (National Commission on Excellence, 1983, para, 24)

Effective leadership for educational success was addressed in this report as an essential tool for reforming the educational system. The commission expressed a broad definition of leadership, citing parental involvement; commitment to high retention rates; teacher dedication; a better understanding of teaching and learning; formulation of solutions to identified problems; policymaker and educator partnership; federal government provisions to states, local, and other resources for the fostering of national education goals; and the importance of the American community to volunteer, support, and make a public commitment to help strengthen educational programs (National Commission on Excellence, 1983, para, 30). 
Response to $\boldsymbol{A}$ Nation At Risk. As part of his 1984 campaign, Reagan attended regional meetings concerning $A$ Nation at Risk. Individual state legislatures and state departments of education worked on state reforms to improve education at the state and local level. Although many states and local school districts responded positively to the recommendations of $A$ Nation at Risk, policymakers were disappointed in the low student achievement scores and the continued gap between the advantaged and disadvantaged students (Bell, 1988).

Policymakers vowed to restructure schools and place more emphasis on classroom improvement. Throughout the 1980 s, additional panels, reports, and legislation were initiated by states, policymakers, and groups worked to identify a need in public education reform that brought about greater accountability. In Arkansas, 122 education bills were passed between 1983 and 1984. Forty-four states raised high school graduation requirements; dozens of states heightened standards for teachers and increased instructional time in the classroom. Illinois compiled a book of Illinois reform efforts and sent it to educators across the state. This compilation of reforms came as a document "dressed up like a gift, complete with a bow on the cover" (Hunt, 2008, p. 581). In 1984, Reagan outlined four national goals in education to be reached by 1990 :

- high school graduation rate to reach more than $90 \%$,

- college admission test scores to be above the average set in 1985 ,

- salaries for teachers to be competitive with entry-level business and engineering salaries, and

- increase high school graduation requirements. (Ysseldyke \& Algozzine, 2006, p. 20)

Governors acknowledged the need to gather reliable state-level data on student achievement outside of the ACT or SAT assessment scores. The Southern Regional Educational Board, comprised of such governors as Lamar Alexander (Tennessee), 
Richard Riley (South Carolina), and Bill Clinton (Arkansas), called for state comparisons on student achievement. The National Governors Association (NGA), established in 1908 , took a renewed interest in educational reform under Reagan's administration. "The growing alliance between the Department of Education and state governors in the 1980s was to a large degree facilitated by earlier restructuring of federal and state education agencies" (Peterson, 2003, p. 12).

Increased accountability. In the 1980 s era of increased reform reports, legislation, requirements, and committee discussions on improving education, resistance was met from educators and the unions. Those involved in the resistance felt this was a top-down approach to reform (Peterson, 2003). As a result, the NGA proposed a bottomup approach, providing schools with more autonomy. With this autonomy came increased accountability for schools within reform efforts. Responding to educator frustration, the NGA told educators the board would "regulate less, if schools and school districts will produce better results" (National Governors' Association, 1986, p. 3). At the 1986 NGA annual meeting, reports were given on the work of seven task forces created in 1985 to study school leadership, teaching, school choice, student readiness, facilities, technology, and college student preparedness for the workforce. The report, entitled Time for Results: The Governors' 1991 Report on Education, was released in 1986 and provided states with information on necessary actions to reform education in the next 5 years.

Student achievement measures. The National Assessment of Educational Progress (NAEP), a panel headed by state governors to analyze student progress, debated the use of state comparisons of student achievement. Prior to the NAEP panel analysis of 
student progress, Secretary Bell initiated the "wall chart," where student achievement data was compared across states. In May 1986, Secretary William J. Bennett, who replaced Secretary Bell, formed a NAEP study group to analyze the value of the NAEP and state-level information on student achievement. In 1987, the committee released the Alexander-James Report, which praised the value of NAEP but criticized the lack of state-level information. The report expressed the importance of comparing the progress of American children as a whole when using that information to determine America's position among other nations. The weakness, the report stated, was that education was a state responsibility - therefore, it was more important to compare the progress of students within each state (Alexander \& James, 1987, pp. 4-5). This report became a key document in the reorganization of both NAEP and ESEA by guiding policymakers in decisions of state accountability in future educational reform efforts. The final reauthorization legislation, entitled Augustus F. Hawkins-Robert T. Stafford Elementary and Secondary School Improvement Amendments of 1988, "assigned policy oversight... and limited state-level tests to trial assessment in mathematics and reading for those states that chose voluntary participation" (Vinovskis, 2009, p. 19). These goals did not pertain to principal accountability in the evaluation of teachers.

Additional accountability measures. Following the final reauthorization in 1988, Congress created the National Assessment Governing Board (NAGB), an accountability subcommittee of NAEP, to "develop assessments and standards for national, regional, and state comparisons of achievement in reading, mathematics, science, and other subjects" (Peterson, 2003, p. 307). Along with the National Assessment Governing Board, the NGA vowed to hold schools accountable by reporting student achievement. 
Though accountability was part of the initial $A$ Nation at Risk recommendations in 1983, by 1988 policymakers allowed for voluntary participation, trial assessments in subject areas, and prohibited information to be used in ranking local, district, or state educational systems (Vinovskis, 2009). The excellence movement in the early and mid-1980s promoted leadership among administrators. These reform initiatives dealt with specific requirements for the school system as a whole but not with specific accountability measures for principals in the evaluation of teachers in relation to student achievement.

\section{The 1990s}

Business-style accountability. As George H. W. Bush became president in 1989 , the push for educational reform under $A$ Nation at Risk continued. Shortly after his inauguration, Bush called state governors to a national education summit to establish national education goals for America's public school system. Prior to the summit date, members of the National Governors Association (NGA) held ideas concerning goals and the timeframe in which they should be attained. On September 13, the NGA held an outreach meeting, working with education, business, advocacy, and government organizations through discussions and testimony to help drive final decisions made during the national summit. The discussions and testimony identified four common themes that the governors believed should influence the final decision on Goals 2000 legislation. One theme concerned the need to set and develop a nationwide strategy to meet identified national education goals. No longer would the word 'federal' be used, as it seemed to have a negative connotation that the federal government was overhauling public education. 'Federal' would be changed to 'national'. These national goals were to be performance-based, having the education community involved in both their development 
and implementation. A second common theme was the need for enhanced coordination among the education system and other social and human service agencies. A third theme involved the need to devote resources in the area of early childhood education for 3-and 4-year-old children identified as being at risk. This included educational programs for parents and families of children at risk in order to promote increased involvement in the education of their children. The final common theme dealt with continual growth and self-renewal for schools and educators. It was deemed important for schools and educators to participate in professional development, research, and assessment that would assist in the constantly changing educational needs of children (Vinovskis, 1999).

During the September 27-28, 1989 summit, President Bush, governors, and business leaders "gave impetus to business-style accountability for schools" (Peterson, 2003, p. 306). As the summit unfolded, the Bush administration and the NGA agreed on several issues, such as early childhood education and reducing the high school drop-out rate, yet disagreed on how to define student achievement and whether to include the reduction of the minority achievement gap as a goal. Members agreed that education had always been important, but never more so than at this time. "Our competitors for opportunity are also working to educate their people. As they continue to improve, they make the future a moving target" (The New York Times, 1989, p. 22). Taking the recommendations of the NGA on the identified themes, the president and the governors involved in the summit agreed to focus on four areas. First, to establish a process for setting national goals, and second, to seek greater flexibility and enhanced accountability in the use of federal resources given to states in order to meet those goals. This flexibility and accountability was to be measured through regulatory and legislative changes at the state 
level. This led to the third and fourth areas, where the responsibility to restructure the educational system would lie within individual states, with the requirement for states to annually report on the progress of achieving the goals set nationally. The process of identifying the national goals encompassed the participation of teachers, parents, local administrators, school board members, elected officials, business and labor communities, and the public at large. Not only did the discussions from this summit place increased accountability on states and local school districts, but the committee asked the American public to hold them accountable as well in the achievement of these goals (The New York Times, 1989).

During his State of the Union speech on January 31, 1990, President Bush announced the six national education goals. These six goals stated that by the year 2000

- all children in America would begin school ready to learn;

- $90 \%$ of students would graduate high school;

- students in specific grade levels would exhibit competency in the subject areas of English, mathematics, science, history, and geography;

- American students would be first in the world in math and science achievement;

- every adult would be literate and have skills necessary for the global economy; and

- every school in America would be free of drugs and violence and provide an environment conducive to learning for all children. (Bush, 1990, pp. 147-148)

From excellence to restructuring. As business interest groups were able to influence state legislation on public school policy, the excellence movement ended and the restructuring movement began in education. Most of the reform efforts during the restructuring movement occurred at the district level. Site-based management principles began to take hold in the school systems as school boards and superintendents were encouraged to give control of school-level decisions to individual school principals (Hunt, 2008). The managerial-style skills encouraged for principals in the excellence 
movement were replaced with expectations for principals to be creative about programming decisions, and to be able to help teachers with instructional improvement in the classroom. These approaches called for systematic reform, which was defined as "aligning the chief components of education: goals, curricula, instruction, and tests" (Peterson, 2003, p. 308). State policymakers were expected to set goals and measure progress, yet they were to allow local school districts to develop and implement effective practices as the districts saw fit.

Policymakers believed school accountability entailed "centralization of standards at the state level and decentralization of operational responsibilities to the district or school level" (Peterson, 2003, p. 308). The topic arose again concerning how educational reform efforts would benefit the nationwide education crisis for disadvantaged students. When the summit concluded, Governor Bill Clinton stated it was evident that the country now understood and was committed to the importance and significance education played in the economic future (Weinraub, 1989).

America 2000. By 1991, the Department of Education had begun funding efforts to draft national curriculum standards in core subject areas. State achievement comparison data on student progress was released, and President Bush called another meeting to discuss educational reform efforts. This meeting, held on April 18, was to propose the creation of America 2000, a challenge to American communities to not only embrace the national education goals, but to create local strategies for each of these goals with report cards for measuring progress on their attainment (Vinovskis, 2009). America 2000 focused on school choice, testing, and research. Educators, analysts, and members on Capitol Hill responded positively to the initial announcement of America 2000. The 
positivity was short lived, as criticism began flowing regarding the lack of funding, private school choice, and minimal attention to school readiness and preparation. In early 1991, the Bush administration announced a budget increase of $\$ 29.6$ million in the Department of Education. Only $23 \%$ of this allotment went to this new Bush education incentive (Vinovskis, 2009, p. 45). In a document released by the Institute for Educational Leadership, the opinions of 30 experts were provided in regard to Bush's strategy for reinventing America's schools with America 2000. The following are the opinions of some of these noteworthy experts.

In his opinion article entitled "Bottom-Up Reform From the Top Down," John E. Chubb's analysis of America 2000 was that it put educational decisions back in the hands of state and local officials. He was a proponent of the plan, claiming no other educational reform before it had depended primarily on the cooperation of the states. For financial measures, the strategy relied on businesses rather than taxpayers. The strategy included initiatives that addressed specific weaknesses in schools. Not only were teachers expected to produce results with students, but academies for school leaders were to be created in order to enhance leadership and professionalism (Chubb, 1991). Accountability was also to be measured within the area of expanded school choice for families. "If school autonomy and accountability are key elements of restructuring, educational choice offers clear advantages over the political and bureaucratic organizing principles of education systems" (Chubb, 1991, p. 2).

Richard F. Elmore expanded on the idea of business accountability in America 2000 in his article titled "Would Choice + Competition Yield Quality Education." His conclusion was that choice and competition in isolation would not result in any 
significant improvement in public education. He stressed the need for states and local entities to focus efforts on school improvement in the areas of curriculum development, teacher quality, and professional development for teachers (Elmore, 1991).

Gary Orfield argued that the strategy behind America 2000 promoted a business accountability model that would not work in education. Orfield believed that choice in public schools came from desegregation and the notion of "white flight," in which white families left diverse neighborhoods to seek educational options elsewhere. The Bush administration wanted less bureaucratic involvement in education. "The Bush plan promises large impacts because the market mechanism is expected to force improvements" (Orfield, 1991, p. 13). Orfield used examples of failed business practices such as the savings and loan crisis to show that business leaders, freed from bureaucratic control, made reckless decisions which led to the collapse of the savings and loan marketplace (Orfield, 1991).

Denis P. Doyle argued that America 2000 was just another flawed national education reform because, like other reforms, decisions were not made based on informed research and development. Policymakers made educational reform decisions based on "thought experiments," with no clear decisions based on research. What they thought needed to happen in education were the recommendations already placed in reform initiatives (Doyle, 1991).

Gerald N. Tirozzi also disagreed with the school choice option in America 2000. The possibility of federal funding being funneled to private or parochial schools was in contradiction to the access and equity principles of public education in America. Tirozzi applauded the efforts to promote professional development and rewards for teachers, but 
expected more of a focus on high-quality teachers in the classroom (Tirozzi, 1991). He condemned the administration's decision to use business-backed research and development teams instead of innovations proven to be successful in education. James Comer's program for disadvantaged children and Henry M. Levin's accelerated schools were examples Tirozzi provided as successful educational efforts legislators should utilize in the development of policy and legislation. The argument lay in the rationale of using concepts and strategies proven to be successful in the programs of reformers such as Comer and Levin, instead of creating the "new American schools" listed in the proposal of America 2000 (Tirozzi, 1991, p. 20).

Arguments continued concerning the business-style accountability of America 2000 as George Kaplan expressed disbelief in the ability of this national education policy because the key players who understood education were left out of the decision-making process. He encouraged school board members, superintendents, principals, teachers, students, and parents - who are closest to public schools- to enter the discussion in order to "restore a necessary balance that has been lost during a decade of bashing administrators, school boards, and teachers for doing their job as well as they could under extraordinarily difficult conditions" (Kaplan, 1991, p. 11). Kaplan believed America's obsession with being number one in the world interfered with educational reform. Instead of continuing to degrade the educational system, Kaplan challenged America to start providing the necessary resources to fix the specific areas in need. The area of most need he identified was urban America.

Michael D. Usdan discussed what research and practical experience had shown in previous years: education in America is directly related to the environment in which the 
children reside. He argued that the 535+ New American schools and new businessfunded New American Schools Development Corporation in the America 2000 legislation would not help students in poverty to close the achievement gap. He believed that when children grow up in an environment where learning is valued, student achievement thrives (Usdan, 1991). Michael Timpane (1991) praised the efforts of America 2000 as "important and worth our attention" (p. 19), yet questioned the emphasis on the topic of choice schools and lack of emphasis on working to close the achievement gap between the advantaged and disadvantaged children in America.

Linda Darling-Hammond began her work in education as a teacher's aide in the Cleveland public schools and, at the time of America 2000, she had continued her work in education as an English teacher, curriculum director, reading and study skills teacher, researcher/consultant, and university professor. In a response regarding America 2000, Darling-Hammond (1991) discussed how state and local efforts to improve public schools in America have relied on standardized tests to measure student achievement, inform student placement, and measure both teacher and school quality. She felt that America 2000 was no different in this area, as it proposed to create a national test all states could use for national accountability in public education. Naming previous initiatives and a wide array of measurement assessments, Darling-Hammond formed an educated opinion that assessment cannot be a "constructive lever for reform unless we invest in more educationally useful and valid measures of student learning" (p. 16). For educational reform efforts to yield success, she recommended that efforts be undertaken to improve instruction and enhance the welfare of the students within the schools. 
Oakes (1991) lobbied for fair distribution of resources, including high-quality teachers instead of testing measures, so that all children would have a fair chance in learning. Referencing a study conducted on inequalities in education by the National Science Foundation, Oakes found that students in the black and Hispanic minority groups were given limited access to rigorous coursework, with lower expectations held by the lower-quality teachers of these students. With an even distribution of resources, programs, and teachers, all children would have an equalized opportunity "to become academically competent and workforce-ready" (p. 18).

Teacher preparation in the accountability measures of America 2000 was an area Arthur E. Wise noted as missing. He believed schools could not be improved without first improving the quality of teachers. He argued that if part of the reform effort was to create national common standards to measure student performance, then national common standards for teachers should be used to measure competency in instruction as well (Wise, 1991). States identified their own routes to teacher certification, with no clear criteria to measure competency. America 2000 attempted to address teacher competency in the suggestion of a "governors' academy" for teachers, and by providing more flexibility in teacher certification (Howe II, 1991, p. 26), yet support came only in the form of seed money from the federal government.

Timpane credited the Bush administration for the attempt to provide a useful starting point in the vision to reform American education. He argued the same flaws other experts argued in the areas of national assessment, parental choice in schools, and federal investments. Timpane also asserted that America should not wait for privatelyfunded groups to come up with ideas that were already being discussed by educational 
experts such as Ted Sizer, James Comer, and Bob Slavin (Timpane, 1991). The problem, Timpane believed, was finding ways to cut through bureaucracy in order to get this information to principals and teachers in every school. He raised the question of whether or not the American public believed and trusted educators, and felt support must be given to the educators within the schools, not assigned by outside experts with no preparation or knowledge of instruction (Timpane, 1991).

Jose A. Cardenas maintained that the idea of working to close the achievement gap for disadvantaged children in American schools would continue to be argued when new standards were not devised to match the new strategies. He believed it was unlikely that students in minority groups would do better in state or national assessments without changes to instructional practice within the schools. If students were to reach higher expectations in achievement, then new standards needed to be addressed; and assistance given to students who did not perform well (Cardenas, 1991). Educators need "direction, support and resources...to address these adequacies in existing schools" (Cardenas, 1991, p. 29). Bernard C. Watson (1991) joined the argument concerning past educational reforms that continued to fail to meet the needs of disadvantaged children. He argued that reform does not happen without the incorporation of additional resources in education. Watson maintained that if Americans wanted higher standards for both schools and students, the focus needed to shift from the development of higher standards to the development of specific teaching methods. With the development of specific teaching methods, student achievement would increase and high standards would be met. Assigning additional resources to priority areas will 'create improvement and maintain quality for all of this country's children and youth, not just those who already have 
distinct advantages" (Watson, 1991, p. 32). "America 2000 celebrates assessments but never mentions equity or diversity" (Lewis, 1991, p. 35). No ideas were provided on how to help teachers become more successful in dealing with students from diverse populations. The connection was missed between the failure of students and the failure of educational reform to change teaching (Lewis, 1991).

America 2000 is a step in the right direction, but what is needed is more than a step. It is a journey, and schools aren't going to be able to get there if we just send them off with new demands and little help from the rest of the community's resources. (Gardner, 1991, p. 45)

In spite of the criticism surrounding America 2000, William W. Wayson praised the ability of the reform effort to give attention to the importance of approaching improvement systematically, from government action and community support to school personnel and policymakers. "Creating and sustaining forums in which communities discuss what they can do to develop the best schools in the world might well be the best contribution to come from America 2000" (Wayson, 1991, p. 48). Wayson agreed that business-style accountability of competition as a motivator for change in education was unjust and would not help overall student outcomes. The difference between education and the business world was the fact that administrators in education were not able to use the type of techniques used in the business world to control their markets (Wayson, 1991). And yet again, a disparity is evident in principal accountability in teacher evaluation as it relates to student achievement.

In his book The Predictable Failure of Educational Reform, Seymour B. Sarason pointed out that the people responsible for making the changes necessary to improve education in American schools were the teachers. He believed that reform efforts failed to include teachers in the discussion about necessary changes and the methods for 
supporting teachers in change efforts. Edward J. Meade, Jr., who participated in analyzing reform efforts for more than 30 years, found that leadership was essential for the improvement of schools. From his experience in schools and in reform efforts, he found that leadership must come from the school principal, who has the duty to help teachers, students, and parents fulfill the vision.

Accountability is made more certain and more accurate when those who are held accountable (principals, teachers and other school staff) understand the expected objectives and goals and are allowed and expected to use their professional judgment on how the school's instructional effort shall function to achieve such goals. (Meade, 1991, p. 47)

States were encouraged to participate in America 2000. Colorado became the first state to begin discussions on state reform efforts as a result of America 2000. Under the leadership of Colorado Governor Roy Romer, state legislators, educators, and business leaders adopted the six national education goals and launched Colorado 2000. A total of 44 additional states, including Illinois, followed suit in an agreement to support the initiatives of America 2000 by developing achievement strategies, creating state report cards to measure student progress, and supporting the development of new schools (Vinovskis, 2009, p. 50).

As the Senate and House debated America 2000, the National Council on Education Standards and Testing (NCEST) issued a report in January 1992 urging systematic reform in public education through the creation of national educational standards and assessments (Koretz, 1992). In response to this report, the Bush administration began a national push for systematic educational reform. Included in their recommendations was a focus on moving "accountability away from measures of inputs and processes to evidence of progress toward desired outcomes...focused on the system of assessments and 
the use of the results for accountability" (National Council on Education Standards and Testing [NCEST], 1992, pp. 17-18). Referencing themselves as well as other education experts such as Linda Darling-Hammond and Richard Jaeger, testimony was brought before Congress by Daniel M. Koretz, Senior Social Scientist for RAND publications on behalf of George F. Madaus, Edward Haertel, and Albert E. Beaton. These education experts in the area of measurement gave testimony regarding rationale on why the recommendations of NCEST were insufficient for reforming America's public schools (RAND, 1992). In the testimony, certain areas of the NCEST recommendations were mentioned as critical for analysis. The education experts claimed that the system of testing and the creation of national standards would narrow instruction and force an emphasis on teaching to the test. They argued that the report's recommendations for providing incentives to teachers for the improvement of instruction and for students to work harder across all age levels, diversities, and socioeconomic statuses were contradictory to what research had proven to enhance equity in student achievement (Koretz, 1992). Finally, they contended that the cost of implementing the recommendations from NCEST had not been examined thoroughly. Along with criticism, the educational measurement experts offered alternative directions for the reform of America's public school system. These recommendations included an endorsement to continue the national debate on standards in education with a need to "validate the standards and confirm empirically that the standards actually reflect what is needed" (Koretz, 1992, p. 12); clarification was needed on what schools must provide in order to claim equity in the delivery of standards; a focused effort on research and development was necessary in order to support the quality and effects of assessment, reliability, and equity of scores; and a nonpartisan body of credible experts 
needed to continually evaluate these efforts (Koretz, 1992).

While George H. W. Bush campaigned for re-election against Arkansas Governor William (Bill) Clinton, criticism continued to surround America 2000. Though the proposed legislation was passed in the House, debate within the Senate held up the final confirmation process. Ultimately, the proposed America 2000 Excellence in Education Act, an attempt at the reauthorization of ESEA, never made it through Congress before President Bush's term expired.

Systemic reform. As President Clinton took office in 1993, education groups continued to offer advice and opinions moved to the idea of systematic reform efforts in education. The newly-appointed Secretary of Education, Richard Riley, formerly the governor of South Carolina and a member of the NGA in the 1980s, led the Clinton administration in working with education groups such as the National School Board Association, the National Education Association, and the Progressive Policy Institute regarding continued educational improvements. Working together with these groups, the Clinton administration called for new approaches to reform efforts in an attempt to reauthorize ESEA, which was set to expire at the end of 1993. As discussion continued on the reauthorization of ESEA, President Clinton's administration adopted the principle of lifelong learning, spanning educational programming from early childhood through adult literacy. In the administration's discussions with education advocacy groups, the advocacy groups "stressed the inadequacy of the current federal compensatory education programs and favored instead those based on national education standards and systemic reform" (Vinovskis, 2009, p. 66). 
Instead of moving ahead with the reauthorization of ESEA, in February 1993 President Clinton and Secretary Riley, under the guidance and continuation of Bush's America 2000, announced a forthcoming bill entitled Goals 2000: Educate America Act. The purpose of Goals 2000 was to provide a framework for meeting the National Education Goals (Mulcahy, 1994).

The framework of Goals 2000 promoted systematic education reform. Systematic education would reform schools by improving teaching and learning. Having clear, defining roles and the support of the federal, state, and local responsibilities, equitable opportunities for all children to learn would be enhanced. The opportunities to learn included focused efforts on high-quality standards and assessments by assisting elementary and secondary schools in involving parents to support and advocate for their children's education (Mulcahy, 1994). Clinton's administration worked with elite education bureaucrats, namely Marshall Smith, Chester Finn, Jr., Diane Ravitch, Marc Tucker, Robert Schwartz, Michael Cohen, and Gordon Amback. With these elite education bureaucrats, the Clinton administration enacted "the first truly national education policy in U.S. history: standards-based reform" (Nitta, 2008, p. 47). Goals 2000 and the Improving America's Schools Act required states to create both curricular standards and assessments. The National Education Standards and Improvement Council was charged with the responsibility of holding states accountable in the creation of these standards and assessments (Nitta, 2008). Federal funding was the enforcement mechanism of the Improving America's Schools Act, creating conditions for states to receive federal funding. These conditions included: 
- creating curricular standards,

- developing assessments to measure student progress against these standards,

- annually reporting individual school and district progress, and

- providing assistance to schools that failed to make adequate yearly progress. (Improving America's Schools Act, 1993)

Along with these specified conditions, the Improving America's Schools Act allowed states that met the criteria more flexibility in the way federal education funds were used within the state (Nitta, 2008, p. 47).

We must have national goals to move the entire system of education forward. The legislation makes the National Education Goals a matter of formal national policy. ...As important as goals and standards are, they alone are not enough. We must also find ways of ensuring that students have an available opportunity to learn and an educational environment to succeed. (Improving America's Schools Act, 1993)

As the Clinton administration, led by Secretary Riley, looked at both Goals 2000 and the reauthorization of ESEA, systematic reform focused on the classroom by starting with a clear set of goals in the form of challenging content standards to establish what students should know and be able to do (Nitta, 2008). To accomplish this, focus was given to the improvement of curriculum, instruction, and assessment within the schools.

With broad bipartisanship, President Clinton signed into law the Goals 2000: Educate America Act of 1994 on March 31, 1994, mandating the creation of the National Education Standards and Improvement Council (NESIC). The main responsibility of NESIC was to analyze the development of state and national education standards. Goals 2000 solidified the notion that although education was a national priority, it was a state and local responsibility (Friedman, 2004, p. 60). Goals 2000 encouraged states to set high standards for student achievement, and supported schools, communities, and states with federal grant funding to begin this endeavor. This legislation supported the provision of federal funds in the form of grants to state and local school districts to incorporate 
rigorous academic standards, curriculum alignment, teacher education, and incentives for students to meet high standards for academic achievement (Improving America's Schools Act, 1993). Even with all of this legislation, there was nothing in the Act pertaining to principal accountability to evaluate teachers and its relation to student achievement.

Reauthorization of ESEA. As Clinton's term continued, national curriculum standards were released and the second national education summit of governors "pledged to set standards at the state and local levels" (Peterson, 2003, p. 307). Though Goals 2000 codified national education goals, curriculum directors across the nation treated the national standards as a resource, but not a blueprint for transforming curriculum to enhance student achievement (Willis, 1994). Federal funding accountability continued to be discussed. In a push for the Clinton administration to reauthorize Title I of ESEA in 1994, Senators Ted Kennedy and Claiborn Pell offered a formula for the disbursement of Title I funds (Peterson, 2003). Under their proposal, these funds would be based on factors that included counts of children in poverty, average state per-pupil expenditures, level of state education spending, and extent of school finance equalization within the state (Improving America's Schools Act, 1993). Additional funding recommendations from both the House and the Senate touched on social issues as well: withholding federal funding from local education agencies that violated court orders regarding prayer in public schools, requiring schools to expel students who brought guns to school, and prohibiting funds to be used to disburse condoms or to support homosexuality in public education. Disagreements on the final proposed funding regulations did not stop the reauthorization efforts. The new formula for Title I funding provided less funding to 
high-poverty schools than originally planned. The final passage occurred in the midst of the 1994 mid-term elections.

In 1996, an Appropriations Act amended Goals 2000 to clarify misinformation and misconceptions (U.S. Department of Education, 1998). This attempt began with the explanation in Section 318 of Goals 2000 that with this reform legislation, the federal government would not take over education. Education still remained in the control of the state and local educational agencies. Other myths clarified by the amended Goals 2000 concerned the push of the American public school system toward outcome-based education (U.S. Department of Education, 1998). The Department of Education clarified that the legislation of Goals 2000 did not promote a particular educational philosophy, but instead focused on increasing academic achievement and preparing students for the workforce. The adoption of educational philosophies was left up to individual school districts or states. The national standards were a guideline provided by NESIC, but were voluntary on the part of states or local educational agencies (The Library of Congress, 2008). Just as with previous educational reform legislation, both praise and criticism rolled in from a variety of educational scholars, experts, and journalists. By 1996, 48 states including Illinois were participating in Goals 2000, and the NGA supported the legislation (Sanchez, 1996). Virginia and New Hampshire were the two states that did not implement Goals 2000. Critiques argued that the legislation lacked substance and focus, and that reaching the goals was unrealistic (Young, 1993). Many believed the goals were unrealistic not because of a lack of interest or effort, but because of the social realities existing for America's school children (Knudsen \& Morrissette, 1998). 
The financing of Goals 2000 was criticized due to the disbursement criteria of grant funds to states and local educational agencies. Grant money for Goals 2000 required states to submit a plan to the federal government for improving schools within the state. To make changes to the plan, individual states needed approval from the U.S. Secretary of Education (Schrock, 1996). Specifically, the state of Virginia claimed they would lose state and local control of decision making if they accepted federal grant money to implement Goals 2000 (The Washington Post, 1996).

Goals 2000 retained the original six national education goals and in 1996, added two more accountability goals dealing with the professional development of teachers and parental participation. The national education goals to be reached by the year 2000 focused on the areas of:

- school readiness;

- school completion;

- student achievement and citizenship;

- teacher education and professional development;

- mathematics and science;

- adult literacy and lifelong learning;

- safe, disciplined, and alcohol- and drug-free schools; and

- parental participation. (Public Law 103-227, 1994)

Improving America's Schools Act, renamed Goals 2000: Educate America Act, was an act to improve learning and teaching by providing a national framework for education reform; to promote the research, consensus building, and systematic changes needed to ensure equitable educational opportunities and high levels of educational achievement for all American students; to provide a framework for reauthorization of all federal education programs; to promote the development and adoption of a voluntary national system of skills standards and certifications; and for other purposes (Public Law 103-227, 1994). Specifically addressed was Title II (National Education Reform Leadership, Standards, 
and Assessments-Part A: National Education Goals Panel), which established the National Education Goals Panel in the executive branch to report annual progress and to direct improvement methods for assessing school readiness for all children (Library of Congress, n.d.). Title III (State and Local Education Systemic Improvement) established a 5-year grant program for state and local education agencies. Section 306 required state improvement plans that included strategies to improve and measure accountability in teaching and learning. Section 309 required states and local education agencies to provide competitive sub-grants for reform in the areas of preservice teacher education and professional development, focusing grant money on schools with higher percentages of disadvantaged students (The Library of Congress, n.d.).

Though one of the goals focused on improvements in teaching, no accountability for principals in the evaluation of teachers was addressed. Teachers were to be given access to professional development, which was no different than what had been provided to teachers for decades (Knudsen \& Morrissette, 1998). Due to continual debate over the implementation and measurement of the wide variety of proposed accountability measures for public schools, the reauthorization of ESEA was not passed on time. This was the first failure to reauthorize on time in the 35 -year history of the bill. On October 29,2000, the policymakers tentatively agreed to target funding in the areas of school repair and reduction of class sizes, and allowed states to spend a specified percentage on areas they deemed priorities. The final reauthorization of ESEA came through after the 2000 election. By the year 2000 progress had been identified, yet the goals of Goals 2000 had not been reached (Harold-News, 2000). Annual updates by the National Goals Panel were provided to help states monitor progress and identify areas of needed growth. 
State and district bureaucrats, not principals or teachers, were given the flexibility to decide how federal funds would best be used in America's public schools (Nitta, 2008). Goals 2000 did little to empower school principals to create learning teams or innovative programs to improve student achievement (Nitta, 2008). In addition, the design and implementation efforts of Goals 2000 did not fully consider the influence social factors have on families and schools in the drive for student performance (Knudsen \& Morrissette, 1998).

\section{The Twenty-First Century}

No Child Left Behind. President George W. Bush took office in January 2001, immediately announcing his educational plan entitled No Child Left Behind. His appointment for Secretary of Education was Rod Paige. Prior to his appointment as Secretary of Education, Paige served as an officer on the Board of Education in the Houston Independent School District (U.S. Department of Education, 2008). Paige began his educational career as a teacher and coach. He was the first school superintendent to serve as Secretary of Education in the U.S. Department of Education. This plan was announced as a framework for bipartisan reform in education to emphasize George W. Bush's educational philosophy. The No Child Left Behind Act of 2001 (NCLBA), the reauthorization of ESEA, called for state, district, and school accountability; greater choice for parents and students in low-performing schools; increased flexibility in the use of federal education funds for states and local agencies; and a stronger emphasis on the instruction and assessment of reading (U.S. Department of Education, 2004). Additional components of the legislation included the creation of a program to improve teacher and principal quality, based on scientific research, and to 
prepare, train, and recruit teachers of high quality (U.S. Department of Education, 2004). This program was funded by state grants to improve student achievement in the core academic subject areas. For states to receive this grant money, Title IIA Teacher Quality, states were required to report annual student progress. This progress was noted as Adequate Yearly Progress (AYP), and was expected to show evidence of improved student performance in specific academic areas, such as reading, math, and science. States and local educational agencies maintained control of their methods, identifying strategies to meet the needs of both enhanced teacher and principal quality, and improved student achievement. This legislation focused on the following types of projects in order to improve teacher and principal quality to affect student achievement:

- Recruiting and retaining high-quality teachers and principals,

- Reforming both teacher and principal certification programs, and

- Increasing the number of highly qualified teachers in classrooms. (U.S. Department of Education, 2004)

Criteria for these three areas included a needs assessment of the school district, and alignment with state curriculum and assessment standards. School districts were given freedom in how they utilized these funds. Agencies were held accountable to report how the funds were used, as well as to notify the public of annual student achievement on state assessments (U.S. Department of Education, 2004). For teachers to be identified as highly qualified, they were required to meet at least the minimal requirements of a bachelor's degree and full state certification, and to demonstrate subject-matter competency in all subjects they were assigned to teach. These requirements were implemented during the 2005-2006 school year (Essex, 2009, p. 125).

Title II, Part A of NCLBA focused on funds identified for teacher and principal training and recruitment. Section 2101 discussed the purpose of identified regulations for 
teacher and principal training and recruiting funds. These funds were identified for state and local educational agencies, including higher education programs, to help increase student academic achievement through teacher and principal quality. Areas included in the fund section for teachers and principals concerned hiring, recruiting, certification, professional development, technology integration, curriculum and assessment systems, and reforming tenure systems in order to drive instruction for increased student achievement (U.S. Department of Education, 2004). States and local school districts were held accountable in monitoring the use of these funds. States were required to submit an annual report (revised in 2003) to the federal government, stating the number of highly qualified teachers in the No Child Left Behind Consolidated State Report and Performance Based Data Management Initiative.

School leadership regulations were spelled out in Section 2151: National Activities for Demonstrated Effectiveness. In Section 2151, b, 1, the Secretary of the Department of Education was "authorized to establish and carry out a national principal recruitment program to assist high need local educational agencies in recruiting and training principals (including assistant principals)" (U.S. Department of Education, 2004). Activities could include financial incentives for aspiring principals, stipends for principal mentors, instructional leadership and management professional development, and retention of new principals.

Title II Section 2141 of NCLBA referenced "technical assistance and accountability" (U.S. Department of Education, 2004). This section authorized national activities in the areas of teacher, principal, and assistant principal recruitment programs (The Library of Congress, n.d.). Focusing on the accountability description, the act stated that if a 
school failed to meet AYP after 2 consecutive years, the state must identify the school as needing improvement. In addition to this identification, public school choice for parents had to be offered by the following school year, unless prohibited by individual state laws. If after 3 years a state found a local education agency unable to make progress toward meeting the annual measurable objectives and AYP, the state "shall enter into an agreement with such local educational agency on the use of that agency's funds" (U.S. Department of Education, 2004, para. 3). After 4 consecutive years of failing to meet adequate progress, the school underwent one of the stated corrective measures, which included replacement of staff, new curriculum implementation, outside expert appointment to advise the school, school day or year extension, reduction of management at the school level, or change to the internal organizational structure of the school. If a school failed to achieve AYP for 5 consecutive years, the district entered a restructuring plan, which could include its reopening as a charter school, replacement of the school staff, or release of school operation control to the state or private company (U.S. Department of Education, 2003). These corrective measures were only allowed if state laws and regulations permitted them. If a school reached the fourth or fifth year with failure to meet AYP, the state was then deemed responsible for intervention in order to help develop and require the follow-through of a new plan for that local education agency to meet annual measurable objectives. A special rule under Subsection D of the accountability section for schools that did not achieve annual expectations specified that already-granted funds were to be used to enable teachers at those schools to consult with the principal in selecting professional development activities that met the requirement in Section 9101 and to partner with other reform efforts the school was already undertaking (U.S. Department of 
Education, 2004).

The provisions discussed above focused on increasing student achievement through teacher and principal accountability. Other provisions in NCLBA included federal support for English language instruction and efforts to keep schools safe and drug-free.

NCLBA was the most sweeping legislation to reform education and it changed the culture of education in America (Essex, 2009). Under NCLBA, states were required to implement standards-based reform policies and be held accountable for student performance (Superfine, 2008). The act detailed methods of accomplishment by ensuring highquality assessments, accountability systems, teacher preparation programs, curriculum and instruction aligned to state standards, and administrators who measured progress against common expectations for student achievement (Essex, 2009). A strong point of NCLBA was the closing of the achievement gap by meeting the educational needs of children in high-poverty schools, as well as children with limited English proficiency, migratory children, minority and non-minority students, early childhood education, and children with disabilities (Essex, 2009).

Although the act had the potential to improve America's schools, the program's method for evaluation of school performance was flawed. West argued that the measurement system only compared individual students at one point in time to nationally-created standards of performance, which forced states to lower the expectations set for AYP. "The problem is that the NCLB methodology for measuring school performance does not pay enough attention to the vast differences in students' academic preparation when they arrive at school—differences that have clear consequences for their subsequent test 
scores" (West, 2005, para. 14). Disregard for social inequities was again a noted flaw in educational reform efforts. What worked in one state may not work in another, due heavily to the social inequities within each state. The idea for the accountability movement came from state efforts (West, 2005). This was most notable in Texas and North Carolina, where student performance on the National Assessment of Educational Progress dramatically improved. West (2005) maintained that NCLBA should have given more flexibility to all states in education reform efforts, not just states that had already exhibited the ability to increase student performance.

"NCLB provides a standard for equitable access to teacher quality that is both reasonable and feasible. Achieving this goal will require a new vision of the teacher labor market and the framing of a national teacher supply policy" (Hammond \& Sykes, 2003, pp. 1-2). To make NCLBA's requirement of highly-qualified teachers a reality, Hammond and Sykes (2003) claimed the nation had to overcome obstacles in the labor market. These labor market obstacles included inequities in school funding, causing a wide variance in teacher salaries which in turn made certain schools hard to staff. The hardest schools to staff tended to be schools serving disadvantaged children. Hammond and Sykes (2003) believed the provision of requiring highly-qualified teachers in every school would help, but also noted that closure of the achievement gap between advantaged and disadvantaged students by the year 2014 would require dramatic policy changes at all levels. In terms of principal quality and accountability, Kaplan and Owings (2002) argued, "Principals who understand the No Child Left Behind Act of 2001 know how to create and maintain a positive work and learning environment for teachers and students" (Kaplan \& Owings, 2002, p. 37). 
In response to the adoption and implementation of NCLBA, the NGA targeted teacher evaluation policy as a way to meet the highly-qualified teacher requirement (Goldrick, 2002). The NGA identified policy goals for improvement of student learning. These included teacher quality, improving teaching, the incorporation of student learning in teacher evaluation, training evaluators, broadening participation in the design of evaluation systems, and creating professional accountability (Goldrick, 2002). NCLBA "forced teachers and administrators to scrutinize the progress of each child in every academic content area" (Laden, 2010, para. 4). Although accountability measures were brought to both teachers and administrators, no specific accountability measures were outlined for principals in evaluating teachers and its relation to student achievement.

IDEA reauthorization of 2004. In 2004, as the nation was focused on the reform efforts of NCLBA, policymakers were also working to reauthorize the Individuals with Disabilities Act (IDEA) and align the two regulatory reforms. Guidelines on funding, teacher requirements, reporting procedures, and new definitions were provided to align IDEA with NCLBA. The new definitions included "highly qualified," "scientifically based research," "core academic subjects," and "limited English proficiency" (U.S. Department of Education, 2007, para. 2). In the reauthorization of IDEA on December 3, 2004, one specific area was revamped. In the past, IQ achievement discrepancy was used as the primary method to identify children with learning disabilities. With the reauthorization of IDEA, a new system titled Response to Intervention (RTI) was named as the alternative method to identify students with learning disabilities (Fuchs, 2006). This legislation partnered with trends in school wide educational reform, where schools implemented research-based instruction and evaluated the response of individual students to 
the identified intervention (Harlacher, Walker, \& Sanford, 2010). RTI was a process of identifying how well students responded to changes in instruction (Klotz, 2007). The process involved first providing research-based instruction and intervention in the general education curriculum, followed by measures to monitor student progress. Data collected from these progress monitoring measures were then used to guide instruction and educational decisions (Klotz, 2007). RTI was typically a three-tiered approach, where students were identified at varying levels with intensifying services. RTI was a valuable model for schools because it encouraged educators to identify students before academic failure arose (Mellard, 2004).

2008 to the present. As the country transitioned from President Bush to President Barack Obama in January 2009, educational reform discussion remained at the top of the national agenda. The campaign focused heavily on education as Obama promised to work with his administration in the reauthorization of NCLBA. President Obama was inaugurated on January 20th, 2009. Immediately, President Obama announced his choice for Secretary of Education as Arne Duncan, the previous chief executive officer of the Chicago public schools. In Mr. Duncan's tenure with the Chicago public schools, he focused on teacher and principal quality, raising standards and performance levels, and increasing options available to students for optimal learning. One of his most significant accomplishments was bringing the meeting or exceeding reading scores on the third through eighth grade standardized state assessment from a low of $35 \%$ to $58 \%$ and math scores from $46 \%$ to $70.6 \%$ (Illinois Interactive Report Card, 2010). During his confirmation hearings, Duncan stressed his belief that not only was enhancing the education of our American youth a moral obligation, but an economic imperative as well. Placing 
importance on the continual enhancement of education would make America as competitive as possible with the rest of the world (U.S. Department of Education, 2010).

On February 17, 2009, the American Recovery and Reinvestment Act established a budget of $\$ 53.6$ billion for the necessary expenses for state fiscal stabilization in education (The Library of Congress, n.d.). Under Title VIII of the American Recovery and Reinvestment Act, the Department of Education was provided with additional funds to carry out title provisions of ESEA. These funds were targeted for programs for disadvantaged students, school improvement, innovation and improvement, and special education (The Library of Congress, n.d.).

Blueprint guidelines. Working on efforts to reauthorize NCLBA/ESEA, the

Obama administration announced a blueprint for revision on March 13, 2010.

The blueprint challenges the nation to embrace education standards that would put America on a path to global leadership. It provides incentives to states to adopt academic standards that prepare students to succeed in college and the workplace, and create accountability systems that measure student growth toward meeting the goal that all children graduate and succeed in college. (U.S. Department of Education, 2010, para. 2)

The blueprint included reform proposals in the areas of

- science, technology, engineering, and mathematics education;

- family and community support;

- teacher support;

- standards and assessments for college- and career-readiness;

- a complete education;

- diverse learners;

- early learning;

- public school choice;

- rewarding excellence and innovation; and

- turning around low-performing schools (U.S. Department of Education, 2010, para. 3).

The blueprint addressed the empowerment of educators by respecting teachers as professionals and recognizing their importance. The blueprint stresses that great teachers 
matter and that not all teachers are equally effective (U.S. Department of Education, 2010). To support this understanding, the blueprint planned to incorporate methods where principals and other school leaders evaluate "teachers comprehensively and fairly based on individual performance" (U.S. Department of Education, 2010, para. 4). In the legislation, a section supporting the understanding of and commitment to teacher evaluation was entitled Great Teachers and Great Leaders. The proposal asked states and local districts to put specific conditions in place that allow teachers, principals, and leaders at all levels to gain meaningful information to positively affect student achievement. This new approach to the creation of great teachers and leaders incorporated four criteria:

- elevating the profession and focusing on recruiting, preparing, developing, and rewarding effective teachers and leaders;

- focusing on teacher and leader effectiveness in improving student outcomes;

- supporting states and districts willing to take bold action to increase the number of effective teachers and leaders where they are needed most; and

- strengthening pathways to teaching and school leadership positions in highneed schools. (U.S. Department of Education, 2010)

Federal funding in the form of grants would continue to be given to states and school districts to follow through on the proposals of ESEA. States and school districts were permitted to decide how those grant funds would be used, as long as they met the criteria of improving teacher and principal effectiveness and ensured that teachers and principals were distributed equitably. Criteria for measuring, developing, and improving teachers and leaders were to be included in specific policies and systems for states and local school districts to receive grant funds. States and school districts were required to collaborate with teachers, principals, and other education stakeholders to include statewide definitions of the following phrases: effective teacher, effective principal, highlyeffective teacher, and highly-effective principal. State-level data systems were incorpor- 
ated to follow teachers and principals from their preparation programs to job placement, student growth, and retention outcomes. Finally, district-level evaluation systems were to be put in place for both principals and teachers that provided at least three performance levels; directly related to the state definitions for effective and highly-effective teachers and principals; provided meaningful feedback so teachers and principals could both improve their practice and inform future professional development; and developed in collaboration with teachers, principals, and other education stakeholders (U.S. Department of Education, 2010).

States and school districts would be given funds to develop effective teachers and leaders who met the local needs. This could include recruitment, career ladder development, certification and retention policy improvements, strengthening preparation programs, development of teacher and principal evaluation systems, improving instructional practice through targeted professional development, or class size reduction. Any of these chosen by a state or school district must be aligned with evidence of improved student learning. To hold states and school districts accountable, both were required to publish report cards at least every 2 years to provide information on key indicators of teacher and principal effectiveness. These key indicators were a listing of qualifications; a teacher survey collecting data on levels of support and working conditions of the school; years of experience for teachers and principals in each school; attendance of teachers and principals; and retention rates of teachers (U.S. Department of Education, 2010).

ESEA detailed the push for transformation leadership in student achievement. For states and local school districts to secure funds, they were required to either possess a record of preparing effective leaders or commit to a method of tracking and measuring 
the effectiveness of program graduates. The preparation program was required to have a residency or field-based component, followed by an induction and mentoring-style program for new principals in order to facilitate greater success. Priority was given to states that committed to creating conditions that increased the "likelihood that their graduates and other principals will succeed in improving low-performing schools" (U.S. Department of Education, 2010, p. 18).

The ESEA blueprint proposed "cross-cutting priorities" to support the work this legislation required states and local districts to perform. With the ESEA blueprint, the Obama administration sought to "redefine the federal role in education" (U.S. Department of Education, 2010, p. 39). This reform effort shifted from compliance to innovation with the promise of rewarding success and fostering collaborative relationships. The Obama administration envisioned the federal role as one of flexibility, as long as states and local districts continued to focus on improving outcomes for students (U.S. Department of Education, 2010). In addition to providing flexibility, those states and local districts that were successful at improving outcomes for students would be rewarded and given the opportunity for additional funds to share the successful strategies with other states and school districts. "This will ensure that federal funds flow to projects that are successfully serving students" (U.S. Department of Education, 2010, para. 4). Finally, the blueprint fostered an ongoing improvement evaluation for not only states and local districts, but for the ESEA proposal as well. A biennial report evaluating the performance measures of ESEA would be given to Congress, along with an independent panel, to advise plan enhancements. Federal, state, and local districts were encouraged to collaborate on the use of data for continuous program improvement and evaluation. 
Race to the Top. The blueprint incorporated a competitive grant process. This competitive grant process was called Race to the Top (RTTT). On April 6, 2010, Secretary Duncan released the application and deadline dates for phase one of Race to the Top grant funds. Authorized under the American Recovery and Reinvestment Act of 2009 (ARRA), Race to the Top was an incentive program designed to provide funding to states and local school districts that committed to drastic educational reforms to increase student achievement. The grant money involved two competitions: Comprehensive Assessment System grant and High School Course Assessment grant (U.S. Department of Education, 2010). The application was a lengthy process, detailing exactly what the states or local districts planned to do with the grant money in order to meet the criteria set in the ESEA provisions. States submitted these applications on a voluntary basis.

For phase one of Race to the Top, 40 states plus the District of Columbia submitted applications (U.S. Department of Education, 2010). On March 29, 2010, Secretary Duncan announced the winners of the first installment of Race to the Top. Grant money would go to the states of Delaware and Tennessee. Delaware and Tennessee received the highest marks by the peer review panel for the commitment they both detailed in reforming education with key stakeholders that included elected officials, teachers' union leaders, and business leaders. "In both states, all school districts committed to implementing Race to the Top reforms" (U.S. Department of Education, 2010, para. 8). Both Delaware and Tennessee detailed plans to improve teacher and principal evaluation, and put laws and policies in place to support these reform efforts.

States and local districts were given another opportunity to submit applications for phase two of Race to the Top. The promise of providing transparency was exhibited 
as the Department of Education made public the individual state plans, along with scores and remarks from the peer review panel. The deadline for phase two applications was June 1, 2010. On September 2, 2010, the winners of the phase two Race to the Top grant funds were announced. The winning applicants, selected by a panel of peer reviewers, included nine states plus the District of Columbia. "Every state that applied showed a tremendous amount of leadership and a bold commitment to education reform. We set a high bar and these states met the challenge" (U.S. Department of Education, 2010). The winners were Massachusetts, New York, Hawaii, Florida, Rhode Island, District of Columbia, Maryland, Georgia, North Carolina, and Ohio.

The 10 winning applications have adopted rigorous common, college- and careerready standards in reading and math, created pipelines and incentive to put the most effective teachers in high-need schools, and all have alternative pathways to teacher and principal certification. (U.S. Department of Education, 2010, para. 13)

Race to the Top has ignited educational reform discussion as states continue devising ways of committing to bold reform efforts in attempts to secure federal funding. As of March 2011, 43 states, including the U.S. Virgin Islands, had committed to reform individual state curricular standards with the adoption of a national set of standards called the Common Core Standards (Common Core, 2011). This means all of these states will follow the same standards for what students should know and be able to do at each grade level and subject area. With this latest educational reform effort, individual states are encouraged to create measures for principal accountability in the evaluation of teachers to positively impact student achievement. Table 1 shows an abbreviated summary of federal education reform efforts. 


\section{Table 1}

Federal Reform Efforts

\begin{tabular}{|c|c|c|c|c|}
\hline $\begin{array}{l}\text { Federal Reform } \\
\text { Efforts }\end{array}$ & $\begin{array}{l}\text { Historical } \\
\text { Place }\end{array}$ & Goals/Objectives & Achievements & $\begin{array}{l}\text { Does a relationship to } \\
\text { principal accountability in the } \\
\text { evaluation of teachers for } \\
\text { student achievement exist? }\end{array}$ \\
\hline $\begin{array}{l}\text { Common School } \\
\text { Movement }\end{array}$ & Mid-1800s & $\begin{array}{l}\text { Providing education for all, not just the } \\
\text { wealthy }\end{array}$ & $\begin{array}{l}\text { Creation of a state board of education; } \\
\text { increased student attendance; established } \\
50 \text { high schools; attained state tax for } \\
\text { salaries and new schools; created normal } \\
\text { schools to focus on teacher training and } \\
\text { preparation }\end{array}$ & No \\
\hline Morrill Act & 1862 & Promote and support higher education & $\begin{array}{l}\text { Land granted to states who focused instruc- } \\
\text { tion on agriculture and mechanical arts; } \\
\text { defined the federal governments role as } \\
\text { one of "supplementary assistance" to state } \\
\text { educational systems }\end{array}$ & No \\
\hline $\begin{array}{l}\text { Progressive } \\
\text { Movement }\end{array}$ & $\begin{array}{l}\text { Began at } \\
\text { the turn of } \\
\text { the } 20^{\text {th }} \\
\text { century }\end{array}$ & $\begin{array}{l}\text { Practical instruction in schools; } \\
\text { modern teaching methods; recognition } \\
\text { that all students can learn; educating } \\
\text { the whole child; greater emphasis on } \\
\text { teacher training and certification }\end{array}$ & $\begin{array}{l}\text { Educational theories tested by John } \\
\text { Dewey; creation of the Progressive } \\
\text { Education Association; creation of the } \\
\text { national teachers examination }\end{array}$ & No \\
\hline $\begin{array}{l}\text { Measurement } \\
\text { Movement }\end{array}$ & Early $1900 \mathrm{~s}$ & $\begin{array}{l}\text { Increased use and application of } \\
\text { intelligence and aptitude tests }\end{array}$ & $\begin{array}{l}\text { Initiated the push for intelligence and } \\
\text { standardized testing }\end{array}$ & No \\
\hline $\begin{array}{l}\text { The Smiths-Hughes } \\
\text { Act }\end{array}$ & 1917 & $\begin{array}{l}\text { Promote and support public initiatives } \\
\text { in education }\end{array}$ & $\begin{array}{l}\text { Provided federal aid to states that supported } \\
\text { vocational education below the college level }\end{array}$ & No \\
\hline $\begin{array}{l}\text { (American public } \\
\text { made aware of an } \\
\text { educational crisis) }\end{array}$ & $\begin{array}{l}\text { 1955-Rudolf } \\
\text { Flesch writes } \\
\text { Why Johnny } \\
\text { Can't Read } \\
\text { 1957-USSR } \\
\text { launches } \\
\text { Sputnik }\end{array}$ & $\begin{array}{l}\text { Heighten the American public's aware- } \\
\text { ness of the educational crisis that was } \\
\text { now cause for a sense of fear that other } \\
\text { countries could overtake the U.S. }\end{array}$ & $\begin{array}{l}\text { Heightened the American public's aware- } \\
\text { ness of the educational crisis and drove } \\
\text { policymakers and legislators to brainstorm } \\
\text { reform efforts }\end{array}$ & No \\
\hline
\end{tabular}




\begin{tabular}{|c|c|c|c|c|}
\hline $\begin{array}{l}\text { National Defense } \\
\text { Education Act }\end{array}$ & 1958 & $\begin{array}{l}\text { Increase categorical aid to states for } \\
\text { educational purposes; better prepare } \\
\text { America to compete globally }\end{array}$ & $\begin{array}{l}\text { Increased funding for math, science, and } \\
\text { foreign language curricula }\end{array}$ & No \\
\hline Civil Rights Act & 1964 & $\begin{array}{l}\text { Federal financial assistance to public } \\
\text { schools to support desegregation }\end{array}$ & $\begin{array}{l}\text { Title VI funds were given to states who } \\
\text { agreed to desegregate schools }\end{array}$ & No \\
\hline $\begin{array}{l}\text { Economic } \\
\text { Opportunity Act }\end{array}$ & 1964 & $\begin{array}{l}\text { Improve educational preparation for } \\
\text { students in poverty }\end{array}$ & $\begin{array}{l}\text { Creation of community programs: Upward } \\
\text { Bound and Project Head Start }\end{array}$ & No \\
\hline $\begin{array}{l}\text { Elementary and } \\
\text { Secondary } \\
\text { Education Act }\end{array}$ & 1965 & $\begin{array}{l}\text { Provide funding for culturally } \\
\text { disadvantaged children; provide equal } \\
\text { education for all children }\end{array}$ & $\begin{array}{l}\text { Set the precedent for future federal funding } \\
\text { in K-12 education; five titles providing } \\
\text { funding for: low-income families; school } \\
\text { libraries and instructional materials; } \\
\text { centers offering supplemental education } \\
\text { services; research and training; and to } \\
\text { strengthen state departments of education }\end{array}$ & No \\
\hline $\begin{array}{l}\text { Extension of } \\
\text { Elementary and } \\
\text { Secondary Educa- } \\
\text { tion Assistance }\end{array}$ & $1970 \mathrm{~s}$ & (Continuation of ESEA above) & $\begin{array}{l}\text { Created the National Commission on } \\
\text { School Finance; provided grants to state } \\
\text { and local educational agencies }\end{array}$ & No \\
\hline $\begin{array}{l}\text { Education for All } \\
\text { Handicapped Chil- } \\
\text { dren (renamed in } \\
1990 \text { as the Individ- } \\
\text { uals with Disabilities } \\
\text { Education Act) }\end{array}$ & 1975 & $\begin{array}{l}\text { Provide free and appropriate public } \\
\text { education for all handicapped children }\end{array}$ & $\begin{array}{l}\text { Mandate created to provide a free and } \\
\text { appropriate public education to all } \\
\text { handicapped/disabled children from three } \\
\text { to } 21 \text { years of age }\end{array}$ & No \\
\hline $\begin{array}{l}\text { Creation of the U.S. } \\
\text { Department of } \\
\text { Education }\end{array}$ & 1980 & $\begin{array}{l}\text { Strengthen and streamline federal-state } \\
\text { relations; focus on individual students, } \\
\text { not educational interest groups; allow } \\
\text { more local control in educational deci- } \\
\text { sions; encourage local-level coalitions; } \\
\text { identify local schools as model pro- } \\
\text { grams for the nation; provide equity in } \\
\text { education; and be proactive to educa- } \\
\text { tion and teacher roles in the classroom. }\end{array}$ & $\begin{array}{l}\text { Goals were unmet. The Department of } \\
\text { Education was reorganized in later years. }\end{array}$ & $\begin{array}{l}\text { No but did identify a need to } \\
\text { focus on teacher instruction } \\
\text { in the classroom. }\end{array}$ \\
\hline
\end{tabular}




\begin{tabular}{lll}
\hline Creation of the & 1981 to & $\begin{array}{l}\text { Identify areas of needed improvement } \\
\text { in public education }\end{array}$ \\
$\begin{array}{l}\text { National } \\
\text { Commission on }\end{array}$ & 1987 & \\
Excellence & &
\end{tabular}

The historic report, $A$ Nation At Risk, was created. Began the excellence movement in education; brought stronger public awareness of education; individual states developed state reform efforts to improve education; national goals in education announced; SREB called for state comparisons on student achievement; National Governors Association took a renewed interest in education reform; NAEP debated state comparisons on student achievement
Augustus F.

Hawkins-Robert T

Stafford Elementary and Secondary

School Improvement Amendments

Goals 2000

America 2000

1991-1994

Improving

America's Schools

Act/Goals 2000:

Educate America

Act
Reauthorization of ESEA to bring state accountability in education

Assigned policy oversight and limited state-level tests to trial assessments in math and reading for states that chose to participate.

Never enacted

All children in America would begin school ready to learn; high school graduation rate of $90 \%$; competency in specified grade levels and subject areas; American students would become first in the nation in math and science; every adult would be literate; drug and violence free schools

Same as Goals 2000 with additional focus on the creation of report cards to measure reform progress: school choice, testing, and research

1993-1994 Promote systematic education reform by improving teaching and learning; required states to create curricular standards and assessments; federal funding used to enforce states to comply

Though never enacted, states did continue individual state reform efforts; 45 states adopted the national education goals by developing achievement strategies, creating state report cards, and supporting new school development

Mandated the creation of the National Education Standards and Improvement Council (NESIC); solidified state and local responsibility in education; provided federal funds in the form of grants
No, but effective leadership for educational success was addressed. 


\begin{tabular}{|c|c|c|c|c|}
\hline $\begin{array}{l}\text { ESEA-Title I } \\
\text { Reauthorization }\end{array}$ & 1994 & $\begin{array}{l}\text { Formula for funding disbursement } \\
\text { based on poverty levels, per-pupil } \\
\text { expenditure, state spending level, and } \\
\text { school finance equalization, and social } \\
\text { issues }\end{array}$ & $\begin{array}{l}\text { Provided less funding to high poverty } \\
\text { schools than initially planned }\end{array}$ & No \\
\hline $\begin{array}{l}\text { Appropriates Act to } \\
\text { Amend Goals } 2000 \\
\text { from } 1994\end{array}$ & 1996 & Clarify misconceptions & $\begin{array}{l}\text { Clarified that the federal government } \\
\text { would not take over education; a focus on } \\
\text { increased academic achievement and pre- } \\
\text { paring students for the work place; national } \\
\text { standards were only a guideline and } \\
\text { voluntary }\end{array}$ & No \\
\hline $\begin{array}{l}\text { No Child Left } \\
\text { Behind Act } \\
\text { (NCLBA) }\end{array}$ & 2001 & $\begin{array}{l}\text { Called for state, district, and school } \\
\text { accountability; choice for parents and } \\
\text { students in low-performing schools; } \\
\text { increased flexibility in federal funds; } \\
\text { stronger emphasis on instruction and } \\
\text { assessment of reading; to improve } \\
\text { teacher and principal quality; and to } \\
\text { decrease the achievement gap }\end{array}$ & $\begin{array}{l}\text { States required implementation of } \\
\text { standards-based reform policies; states held } \\
\text { accountable for student performance; NGA } \\
\text { targeted teacher evaluation policy by } \\
\text { identifying goals for improvement of } \\
\text { student learning }\end{array}$ & $\begin{array}{l}\text { No. However accountability } \\
\text { measures for principals and } \\
\text { teachers in high-quality } \\
\text { training and certification } \\
\text { were addressed; as well as } \\
\text { the need to focus on increas- } \\
\text { ing student achievement } \\
\text { through principal and teacher } \\
\text { accountability. The goals of } \\
\text { the NGA because of NCLB } \\
\text { stated training evaluators, } \\
\text { broadening participation in } \\
\text { the design of evaluations } \\
\text { systems, improving student } \\
\text { learning through teacher } \\
\text { evaluation, and creating } \\
\text { professional accountability. }\end{array}$ \\
\hline
\end{tabular}

Reauthorization of $2004 \quad$ Guidelines on funding; teacher Individuals with

Disabilities

Education Act

(IDEA) requirements; reporting procedures;

and new definitions
New definitions: highly qualified, scientifically based research, core academic subjects, and limited English proficiency; Response to Intervention (RtI) named as an alternative method to identifying students with learning disabilities.
No 


\begin{tabular}{|c|c|c|c|c|}
\hline $\begin{array}{l}\text { American Recovery } \\
\text { and Reinvestment } \\
\text { Act }\end{array}$ & 2009 & $\begin{array}{l}\text { Establish funds for state fiscal } \\
\text { stabilization }\end{array}$ & $\begin{array}{l}\text { Department of Education was provided } \\
\text { with a substantial portion of the total } \\
\text { funds. (See State Fiscal Stabilization Fund) }\end{array}$ & No \\
\hline $\begin{array}{l}\text { State Fiscal } \\
\text { Stabilization Fund }\end{array}$ & 2010 & $\begin{array}{l}\text { Provide one-time financial appropria- } \\
\text { tions to states to help stabilize budgets; } \\
\text { focus on supporting low-income } \\
\text { schools, special education improve- } \\
\text { ments, technology, vocational } \\
\text { rehabilitation, independent living } \\
\text { services, and homeless assistance. }\end{array}$ & $\begin{array}{l}\text { Funds were distributed to states to } \\
\text { avoid/minimize reductions in education, } \\
\text { support renovations or repairs in schools, } \\
\text { and enhance or provide continuation of } \\
\text { specific programs. } \\
\text { Added two more accountability goals. }\end{array}$ & No \\
\hline $\begin{array}{l}\text { Reauthorization of } \\
\text { NCLB/ESEA }\end{array}$ & 2010 & $\begin{array}{l}\text { Challenge the nation to embrace edu- } \\
\text { cation standards to put America at the } \\
\text { top globally; provide incentives for } \\
\text { states to adopt academic standards for } \\
\text { college and career readiness; propose } \\
\text { reform in the areas of science, tech- } \\
\text { nology, engineering, and mathematics; } \\
\text { family and community support; teacher } \\
\text { support; standards and assessments for } \\
\text { college-and-career readiness; a com- } \\
\text { p;ete education; diverse learners; early } \\
\text { learning; public school choice; } \\
\text { rewarding excellence and education; } \\
\text { and turning around low-performing } \\
\text { schools (U.S. Dept. of Education, para. } \\
\text { 3). Providing accountability for } \\
\text { teachers and leaders to improve stu- } \\
\text { dent achievement with } 4 \text { criteria: focus } \\
\text { on recruiting, preparing, developing, } \\
\text { and rewarding effective teachers and } \\
\text { leaders; improve student outcomes; } \\
\text { support states and local agencies } \\
\text { willing to take bold action; strengthen } \\
\text { pathways for teaching and leadership } \\
\text { positions in high-need schools (U.S. } \\
\text { Dept. of Education, } 2010 \text { ). }\end{array}$ & $\begin{array}{l}\text { Created a competitive grant process called } \\
\text { Race to the Top (RTTT): Currently, } 11 \\
\text { states plus the District of Columbia have } \\
\text { been awarded grant money for innovative } \\
\text { state reform. } \\
\text { States are creating policies for increased } \\
\text { accountability in teacher evaluation. }\end{array}$ & $\begin{array}{l}\text { Yes: has detailed a push for } \\
\text { transformational leadership in } \\
\text { student achievement. One } \\
\text { means of doing so is through } \\
\text { teacher evaluation. At this } \\
\text { time, Illinois has not been } \\
\text { awarded funding. }\end{array}$ \\
\hline
\end{tabular}




\section{A Selection of State Court Cases on Teacher Evaluation Importance of Evaluation Documentation}

Teacher evaluation is a policy area important to the function of schools.

Administrators must be knowledgeable about legal issues when working to satisfy the requirements and expectations of staff, students, unions, and the public (Sullivan \& Zirkel, 1998). Documentation and individual state law compliance are areas the courts have examined when ruling on cases concerning the dismissal of tenured and non-tenured teachers. Errors on the part of principals in evaluation documentation and state law compliance have caused courts to reverse decisions on teacher terminations. This was evidenced in older court cases, specifically the Nebraska case of Cox v. York County School District (1997), in which a first-year teacher was reinstated because the principal did not comply with the timing requirements of the evaluation process. The Nebraska law required probationary-certified employees to be evaluated once a semester. The first evaluation of Kristen Cox occurred 2 weeks into the second semester. A second formal observation was completed in March. Both evaluations mentioned a need to improve her relationship with students. Cox claimed this was due to several students wanting to drop band during the second semester. Based upon the principal's assessment that band numbers were decreasing, he recommended that the board of education terminate her contract. The board followed through with her termination. Upon final appeal to the Nebraska Supreme Court, the court ordered Cox reinstated as a certified teacher in the school district due to a violation of the timing procedures in the Nebraska state code (Sullivan \& Zirkel, 1998). 


\section{Principal Error}

Similarly, Snyder v. Mendon-Union Local School District Board of Education (1996) was another case of principal error in following evaluation procedures and laws. Lee Ann Snyder was a teacher for 9 years in the Ohio Mendon-Union Local School District. In April 1991, the superintendent informed Snyder that he would not be renewing her contract due to problems caused by discussion surrounding the desire to take the school band to the Liberty Bowl. Snyder was up for contract renewal the same year, and state code required a minimum of two observations, both being at least 30 minutes in length. When the board ruled to not renew her contract, she filed suit on the basis that the observations conducted did not meet the required time of 30 minutes each. Snyder was not only reinstated, but also received back pay due to the principal's failure to evaluate her for the minimum 30 minutes required by Ohio state law (Sullivan \& Zirkel, 1998).

\section{Principal Professional Judgment}

In more recent cases, the courts have allowed education experts to use professional judgment in accordance with state laws. In 2005, a suit was filed in Chicago, Illinois, by a teacher who had been dismissed after 25 years of teaching. The teacher, Charlene Raitzik was dismissed due to receiving unsatisfactory ratings following the evaluation remediation process. Raitzik v. Board of Education (2002), on appeal from the Circuit Court of Cook County, was an important case in Illinois regarding teacher evaluation. Since 1990, Raitzik had received a majority of good ratings on her evaluations, leading to her promotion to tenure status. Throughout these years of evaluation, it was noted that her weaknesses lay in building rapport with students and in communication with parents. Between 1990 and 2000, her teaching assignments varied throughout the 
grade levels. In 1995, Raitzik received an unsatisfactory rating from Principal Alexander, due to her inability to maintain an orderly classroom or carry out disciplinary procedures. Raitzik was placed on a remediation plan, receiving a variety of ratings until successfully completing the remediation with a satisfactory rating. In an attempt to remind teachers of the evaluation procedures and expectations, Principal Alexander held a meeting at the start of the 2000-2001 school year, having all those who attended sign off on their understanding of the expectations. Throughout the 2000-2001 school year, Raitzik was given unsatisfactory ratings, detailing seven areas of deficiency. A mandatory remediation began, with the assignment of a consulting teacher for Raitzik. The consulting teacher, Raitzik, and Principal Alexander met to review the expectations and implementation of the remediation plan. Throughout the remediation process, Alexander followed the requirements: meeting with her eight times, filling out the observation form, and each time conducting a pre- and post-conference. After each post-conference, a signature was obtained as evidence that the meetings occurred. In addition, the consulting teacher provided feedback and opportunities for professional growth to Raitzik. Data was gathered from all evaluations and discussions with the consulting teacher, and Raitzik was notified at the conclusion of the remediation process that she was rated unsatisfactory. She was then dismissed from teaching by the board of education. Raitzik was given her due process rights from a hearing officer who concluded that she should be reinstated. After receiving the hearing officer's recommendation, the board of education rejected the opinion and continued with the termination of Raitzik. Raitzik filed to the trial court for review. The court upheld the board of education's decision, causing Raitzik to appeal on the basis that the principal had failed to follow the 
proper procedure. The Illinois Appellate Court affirmed the trial court's decision, stating that all parties from the school district complied with state law requirements. The court concluded that the principal had done more than the requirements of law, providing the teacher more than the required two observations and keeping accurate documentation of the entire process.

\section{Determining Tenure}

The dismissal of a teacher in her final year of non-tenure status was brought to the court of the state of North Carolina in 2006. In the case of Davis v. Macon County Board of Education, Dorothy Davis filed suit against the Macon County Board of Education, claiming wrongful termination. Before termination notice was given to Davis, the superintendent reviewed the recommendation files from the principals and provided the board of education with the rationale. Davis had been hired in August 2000 to teach high school English. In her 4 years of employment, the principal noted several areas of weakness in her yearly evaluations, including both instructional and professional weaknesses. Some examples included squirting the principal with a water gun in front of students, developing a negative attitude with other teachers, raising her voice during meetings with the principal, and receiving two below-standard ratings on her performance evaluations. Upon presentation of this information to the board of education, the employment of Davis was terminated, effective at the end of the 2003-2004 school year. Davis filed an appeal, claiming the decision was not justified. The trial court upheld the board of education's decision and granted termination. Davis filed a motion for reconsideration, due to inaccurate records being shared during the trial court proceedings. The North Carolina Court of Appeals upheld the decision of the trial court, affirming the right for the board 
of education to terminate Davis in her final year of non-tenure status with the school district. The court referred to the fact that Davis's entire record could be reviewed in the decision, not just the personal differences between Davis and the principal. The two below-standard evaluation ratings were enough to allow the school district to terminate her employment.

\section{Understanding Legalities}

The Supreme Court of Ohio ruled on the teacher evaluation case of Kuptz $v$. Youngstown City School District in March 2008. Charles Kuptz was a certified teacher, employed on a limited contract through Youngstown School District in Ohio in the 20052006 school year. The Ohio statute mandated that a teacher on limited contract must be observed twice a year, with a follow-up report required within 5 days of the observation. In Kuptz's December observation, a follow-up report was not given within 5 days, due in part to Kuptz being absent on the fifth day. The evaluator met with him on the sixth day. At the April board meeting, the Youngstown Board of Education voted to not renew Kuptz's teaching contract for the 2006-2007 school year. A hearing was provided, followed by an appeal to the trial court, which reversed the board's decision. The Ohio Supreme Court, referencing prior court case decisions and the Ohio teacher's contract, held that the board of education did not violate the terms of the contract with the local teachers' union and could terminate Kuptz's employment. The court further explained that the principal was not in violation of the fifth day clause since after Kuptz called off work that day, it was no longer considered a "work day." His next work day was the sixth day after the observation, which was sufficient in following the contractual agreement. 
"Procedural errors still result in reinstatement of teachers, although courts continue their tendency to defer on substantive matters" (Sullivan \& Zirkel, 1998, p. 379). The rulings from these recent teacher evaluation court cases have set the current trend of court decisions on teacher dismissal. These cases showed that courts are becoming less "stringent in enforcing state and local procedural requirements for teacher evaluation" (Zirkel, 2009, p. 71) and are referring back to the expertise of school personnel in making teacher dismissal decisions. Administrators must make informed decisions, while recognizing legal boundaries in teacher evaluation (Sullivan \& Zirkel, 1998). Understanding the legal boundaries allows administrators to make professional judgments when deciding teacher tenure status.

\section{Conclusions}

Federal reform policies and decisions from the courts have addressed the importance of providing an equitable education for all students regardless of race, gender, socioeconomic status, or ability level. Findings from a histography of court cases and educational reforms, specifically from 1965 to the present, have found that policymakers are beginning to bring more principal accountability into school reform efforts. Educational reform policies have focused on a variety of educational areas:

- closing the gap between advantaged and disadvantaged students;

- providing equitable education to children with disabilities;

- restructuring schools to focus on classroom improvements;

- increased accountability in the development of educational goals and standards;

- raising the achievement level of all students and reporting annual progress; 
- training, preparation, mentoring, and continued professional development to ensure high-quality teachers;

- focus on teacher evaluation and evaluator training; and finally

- measured to address teacher and principal accountability in improving student achievement.

As policymakers have been working on one track to improve student learning, scholars and researchers in the field have been working on a separate track, detailing the importance of principal accountability in the evaluation of teachers in relation to student achievement. 


\section{CHAPTER III}

\section{REVIEW OF SCHOLARLY LITERATURE}

Though landmark U.S. Supreme Court cases and federal education reform measures have attempted to increase educational opportunities and achievement for all children in America, scholarly research has focused on principal accountability. Specific to principal accountability, scholars have identified leadership styles and practices that are effective in improving student achievement.

\section{Principal as Instructional Leader}

\section{Leadership Styles}

Several prominent theories in leadership have been influential in guiding school leaders in decisions on what leadership style is most effective in raising student achievement (Marzano, Waters, \& McNulty, 2005). Theories such as transformational leadership, transactional leadership, servant leadership, situational leadership, and instructional leadership guide the debate on effective leadership in schools. The founder of modern leadership theory (Marzano, Waters, \& McNulty, 2005), James Burns, describes leadership as

leaders inducing followers to act for certain goals that represent the values and the motivation - the wants and the needs, the aspirations and expectations - of both leaders and followers. And the genius of leadership lies in the manner in which leaders see and act on their own and their followers' values and motivations. (Burns, 1978, p. 19) 
The two types of leadership Burns describes in his research are transactional and transformational. Transactional leadership entails the leader working with others to exchange one thing for another (Burns, 1978). Typically, the leader works from the effort and reward mindset. The leader responds to issues as they arise and motivates others by promising rewards for desired performance (Marzano, Waters, \& McNulty, 2005). Transformational leadership is seen as "a relationship of mutual stimulation and elevation that converts followers into leaders and may convert leaders into moral agents" (Burns, 1978, p. 4). In this style of leadership, the leader is proactive, has high expectations, creates learning opportunities, and motivates others in order to change the culture of the organization (Bass, 1985 and 1990; Bass \& Avolio, 1994).

An effective leader who desires to help others is described as a servant leader.

Robert K. Greenleaf (2002) describes servant leadership as bringing in the orientation of heart and spirit onto leadership.

It begins with the natural feeling that one wants to serve, to serve first. Then conscious choice brings one to aspire to lead...the difference manifests itself in the care taken by the servant-first to make sure that other people's highest priority needs are being served. (Greenleaf, 2002, p. 27)

Theorists believe individuals can truly lead people and organizations to success by being servant leaders (Greenleaf, 2002; Elmore, 2000; Spillane, Halverson, \& Diamond, 2001). "Servants as followers are as important as servant leaders, and everyone from time to time, may be in both roles" (Greenleaf, 2002, p. 18).

Situational leadership entails the leader's ability to adapt behavior based on the feedback he/she receives from or notices about the followers. This style of leadership involves the leader varying leadership behavior on the ability and willingness levels of the followers. Theorists describe these behaviors as telling, participating, selling, or 
delegating (Hersey, Blanchard, \& Johnson, 2001; Marzano, Waters, \& McNulty, 2005). The leader uses the telling behavior when followers are both unable and unwilling to perform the task. The participating behavior is used when followers are unable but willing to perform the task. The selling behavior comes in when followers are able but unwilling, and the delegating behavior is exhibited when followers are both able and willing to perform the task. The leadership behavior used depends on the situation (Marzano, Waters, \& McNulty, 2005).

Instructional leadership. When instructional leadership first emerged, it was a method of top-down supervision and evaluation of teachers and programs (Catano \& Stronge, 2007). More recent views of instructional leadership center on working collaboratively with teachers to accomplish school-wide goals for increased student achievement (Blasé \& Blasé, 2009). Professional standards in educational leadership have been established to find common expectations for the role of the principal. These guidelines for standards began in the early 1950s and continued to be adjusted by various groups, such as the National Council for the Accreditation of Teacher Education (NCATE), American Association of School Administrators (AASA), and the Committee on the Advancement of School Administration (CASA). Most recently, the Interstate School Leaders Licensure Consortium Standards for School Leaders (ISLLC) and the National Council for the Accreditation of Colleges and Education (NCATE) have worked to develop standards for what principals should know and be able to do (Hoyle, 2006). Kaplan, Owings, and Nunnery (2006) conducted a principal quality study in Virginia, where principals were rated on the ability to perform their duties based on the ISLLC standards. The results of the study mirror the work from a variety of other scholars in the 
discussion that principals must be knowledgeable with curriculum and instruction and conduct effective evaluations of teachers to have an impact on student achievement.

Differing opinions exist on what instructional leadership entails. One viewpoint is that instructional leadership involves encouraging and facilitating teaching and learning, facilitating collaboration among teachers, establishing trusting relationships with teachers and using instructional research to make decisions on school improvement (Blasé \& Blasé, 1999). Another viewpoint argues that instructional leadership is an expansion of transformational leadership, in which principals work to increase efforts on behalf of the organization as a whole (Leithwood, Jantzi, \& Steinback, 1999). Still others believe instructional leadership involves the active collaboration of principals and teachers on curriculum, instruction and assessment (Marks \& Printy, 2003).

Principals can no longer simply be administrators and managers. They must be leaders in improving instruction and student achievement. They must be the force that creates collaboration and cohesion around school learning goals and the commitment to achieve those goals. (National Association of Elementary School Principals, 2008, p. 1)

Accountability with curriculum and instruction. The accountability movement changed the focus of the role principals need to take as instructional leaders (Catano \& Stronge, 2007). A study conducted by Catano and Stronge on principal evaluation instruments raised several questions on the responsibilities of a school principal. Catano and Stronge noted a principal must know and understand his/her expected responsibilities. One of the responsibilities of a principal is to clearly communicate expectations held for teachers in relation to student achievement. Within this study, evaluation instruments were analyzed to determine what the expectations were for principals. Of the evaluations analyzed, $90 \%$ stressed the importance of principals sustaining instructional programs 
that promote both student learning and staff development. With regard to the communication to teachers, principals must lead by example in working to communicate clear expectations on curriculum and instruction (Blasé \& Kirby, 2009). Marzano et al. (2005) argue that effective principals must not only communicate goals for student performance but reinforce the achievement of these goals through use of instructional time within the classroom. Principals should strive to ensure quality instruction by communicating to all stakeholders that learning is the school's most important mission (Stronge, Richard, \& Cantano, 2008).

Subject matter knowledge and pedagogy must be just as important to principals as to teachers. The responsibility lies with the principal to have knowledge of effective practices in curriculum, instruction and assessment in order to provide guidance to teachers for improved teaching and learning (Fullan, 2001). Principals must lead the development and implementation of curriculum and prioritize staff development, yet trust teachers to implement instruction effectively (Portin et al., 2003). Along with this trust, principals must still be the instructional leader to ensure fidelity in the delivery of curriculum and instructional practices (Marzano et al., 2005). To know the curriculum and instruction is not simply enough. Principals must work to be instructional leaders by verifying the curriculum and instructional practices throughout the school (Portin et al., 2003). By making classroom visits, principals can encourage curriculum development, judge the quality of teaching, and share instructional knowledge with teachers (Fink \& Resnick, 2001).

Principals cannot be expected to know all aspects involved in all areas of curriculum and instruction. Blasé and Blasé (2009) and Fullan (2002) found that when 
principals openly discuss and collaborate with teachers on curriculum and instruction, the expertise of all involved enhance continuous school improvement through teacher and student growth. Effective principals, those of high achieving schools, are knowledgeable about curriculum and instruction. These principals not only guide discussion among teachers on instructional practices and curricular programs, they actively participate in this discussion and professional growth opportunities as well (Cotton, 2003).

Accountability in the evaluation of teachers. Principal accountability encompasses more than monitoring and developing curriculum and instruction; teacher evaluation is also important. Teacher evaluation may be the principal's most important responsibility (Hoerr, 2005) and must be conducted responsibly (Danielson, 2008). By law, school districts are required to evaluate teachers (Danielson, 2008) and principals have the responsibility to conduct effective teacher evaluations. The frequency and status of how teacher evaluations are conducted are determined by individual state codes. Principals must know the legalities and follow the contractual agreements when conducting these evaluations to ensure proper procedures are followed. Not only is it important for principals to understand and comply with the legal components of teacher evaluation, it is important that principals provide constructive feedback highlighting strengths and discussing methods for improving weaknesses. Through the evaluation process, principals are able to "judge and develop teacher effectiveness" (Stronge et al., 2008, p. 66).

Teacher evaluation must promote a collaborative growth effort between the principal and the teachers. To achieve this collaboration, the tone of the school climate must be positive. Darling-Hammond (2003) argues that principals need to create a positive school environment in which accomplished teaching can flourish and grow through 
the evaluation process. Therefore, the main purpose of the evaluation process is not to prove teachers incompetent or for principals to intimidate teachers but rather to provide written documentation and constructive feedback with collaborative conversations about teachers' current strengths and areas of needed improvement. Hoerr (2005) agrees that the principal's job is to foster a positive environment that embraces the teacher evaluation process as a means for teachers and student to reach their maximum potential. Teacher evaluation, done correctly, can have a strong effect on overall school improvement (Stronge et al., 2008).

The principal must be accountable for conducting effective teacher evaluations that assist the teacher in improving the quality of instruction over time (Stronge \& Tucker, 2003). To provide effective feedback during the evaluation process, principals observe instruction regularly, through both formal and informal measures. Collaborative, constructive feedback must be give through continual conversations of teacher performance and student progress. Principals must take time to get to know individual teachers' strengths and weaknesses (Blasé \& Kirby, 2009). Principals can do this by making themselves visible throughout the school building. Making regular classroom visits and allowing continual dialogue to occur about curriculum, instruction and assessment helps the principal build positive working relationships with teachers and brings about a collaborative, positive climate toward teacher evaluation (Danielson, 2001).

Several scholars believe that evaluation must include both teacher improvement and accountability (Stronge et al., 2008; McGreal, 1988; Fullan, 1991). Danielson (2008) argues that teacher evaluation has the two essential purposes of ensuring teacher quality and promoting teacher learning. Along with ensuring high quality teaching, the principal 
must develop and implement an effective teacher evaluation system to promote professional learning and continuous improvement (Danielson, 2008). Principals must work to help teachers grow by providing formative evaluations, while working with the teacher to ensure performance results through summative evaluations (Stronge et al., 2008). Danielson (2001) argues that teacher evaluations in the past have failed to fulfill the responsibility of combining accountability with teacher improvement because of poor implementation and a negative atmosphere in which the evaluation takes place. Effective teacher evaluation happens when principals and teachers have open discussions about curriculum and instruction. Throughout the evaluation process, discussion must center on the principal's effort to engage teachers in the best practices known to enhance professional learning (Danielson, 2008). Danielson (2008) argues that in order to provide effective teacher evaluations the evaluation instrument must include a teacher selfassessment and the principal conducting the evaluation must include in the conversation the teachers' reflection on practice. The evaluation process must be a collaborative effort between both the principal and the teacher where strengths and weaknesses are identified to enhance teacher improvement and student achievement. Teaching is difficult and is never perfected (Danielson, 2008); therefore, teachers should view the observation and evaluation process as a growth opportunity, not as a contractual obligation or a way to satisfy state and local codes (Cooper et al., 2005).

Accountability in teacher tenure decisions. According to state and local policies, many school district contractual agreements include provisions for the granting of tenure. Decisions on moving a teacher from probationary status is a crucial decision on the part of the principal. In the same manner, the responsibility to remove teachers, 
either prior to achieving tenure or already in tenure status, who are ineffective in the classroom falls on the principal through the evaluation process (Painter, 2000). Since most states have policies for teacher evaluation in state statutes and the local school district's continuing contracts, it is important that principals know and understand the legal guidelines for teacher evaluation. Effectively evaluating teachers who are on probationary status, i.e., non-tenured, is critically important in the first few years of employment. Tenure status is granted to teachers, dependent on individual state statutes (Essex, 2009), typically after successfully completing a set probationary period. School boards, relying on the expertise and teacher evaluation documentation of the principal, can grant tenure or dismiss a teacher prior to tenure as long as the decisions are not "arbitrary, capricious, or based on political grounds" (Essex, 2009, p. 127).

The idea of tenure was formalized in 1946 when the National Education Association (NEA) introduced a formal proposal. The proposal's primary purpose was to identify procedures that would support the dismissal of incompetent teachers, yet protect competent teachers from dismissal for unjust cause. By the 1960s, most states and school districts had adopted some form of tenure (Marshall et al., 1998) in continuing contracts and state statutes.

Tenure has the potential to help stimulate and foster teacher growth (Marshall et al., 1998). However, Marshall et al. (1998) argue that the current tenure provisions do not promote teacher professionalism and a desire for continuous improvement. Too often, tenure is viewed as a lifetime guarantee of employment (Marshall et al., 1998). What tenure should be is a process where teachers and principals commit to self-directed growth and activism (Marshall et al., 1998). The principal, as instructional leader, is 
responsible to understand the tenure process and conduct effective teacher evaluations that provide the necessary documentation required to make informed decisions on whether or not to grant tenure.

\section{Accountability in student achievement.}

Data analysis. Principal leadership includes empowering teachers to make decisions for student achievement based on data. Principals work indirectly with students by working directly with teachers to analyze student data for curriculum programming and instructional improvements. This data must drive decisions to increase student achievement. "Scores of studies find that student achievement is strongly affected by the leadership of school principals" (Cotton, 2003, p. 62). In 1974, a study confirmed the importance of effective school leadership on student achievement. Published by the State of New York's Office of Education Performance Review, two schools were studied to identify differences in what most positively affected student achievement. One of the findings included the importance of "administrative behavior, policies, and practices in the schools" (Edmonds, 1979, p. 16). The study, conducted by researcher Ronald Admonds, found that the principal was a major factor in positively affecting student achievement. Edmonds highlights studies conducted by other researchers such as Weber (1971), the state of New York's Office of Education (1974), and Madden, Lawson, and Sweet (1976). Weber (1971) studied four inner-city schools deemed to have high levels of student achievement. New York's Office of Education Performance Review study (1974) compared characteristics of two inner-city schools: one with high student achievement and one with low student achievement. Madden, Lawson, and Sweet (1976) conducted a study of 21 California elementary schools to identify characteristics in 
achievement in both high and low performing schools. In each of these studies, Edmonds discussed the common factor of high student achievement linked to strong school leadership and instructional practices. Along with strong school leadership and instruction, the schools all had high expectations for student performance and behavior; and student performance was frequently monitored.

In a comparison study of 784 Texas public school administrators and their ability to influence student achievement in urban, suburban, and rural school districts, specific leadership skills were noted as drivers of higher results. This study confirmed that classroom instruction and quality school leadership strongly influence student achievement (Leithwood et al., 2004). The findings of this study stress the importance of the principal's role in communicating clearly to staff and exhibiting a collaborative leadership style. In addition, the study found the importance of providing professional development to principals in systemic skills, such as staff development, rather than a managerial leadership style (Erwin, Winn, Gentry, \& Cauble, 2010).

In a study conducted by Waters, Marzano, and McNulty (2003), a correlation was found between the school leadership and student achievement. The study found that leadership had a significant impact on student achievement. The correlation was explained in this study as follows:

Consider two schools (school A \& school B) with similar student and teacher populations. Both demonstrate achievement on a standardized, norm-referenced test at the $50^{\text {th }}$ percentile. Principals in both schools are also average-that is, their abilities in the 21 key leadership responsibilities are ranked at the $50^{\text {th }}$ percentile. Now assume that the principal of school B improves her demonstrated abilities in all 21 responsibilities by exactly one standard deviation.... Our research findings indicate that this increase in leadership ability would translate into mean student achievement at school $\mathrm{B}$ that is 10 percentile points higher than school $\mathrm{A}$ (p. 3) 
Setting goals. Setting school goals for student achievement is another important role of the principal. In a study conducted on factors that influenced high student achievement Mendro (1998) found that these schools set goals for student achievement and kept the goals as a central focus. Through goals setting, teachers had high expectations and clearly communicated those expectations consistently to students. The principals of high achieving schools had high expectations for teachers as well, working diligently to remove teachers who were ineffective in the classroom. In a similar study, Cawelti (1999) found that schools with high student performance set specific goals for student achievement. When students are aware of the goals and have clearly defined expectations, they know what is expected and what they need to do to reach those goals. To be an effective instructional leader, the principal must lead this goal setting process by analyzing data to inform decisions.

\section{Teacher and School Level Factors}

When raising student achievement, Marzano (2003) argues there are school-level factors as well as teacher-level factors that make schools successful. Compiling research on school effectiveness from over 35 years, Marzano lists five school-level factors:

- Guaranteed and viable curriculum;

- Challenging goals and effective feedback;

- Parent and community involvement;

- Safe and orderly environment; and

- Collegiality and professionalism. (Marzano, 2003, p. 15)

A guaranteed and viable curriculum, followed by challenging goals and effective feedback are the most important factors in affecting student achievement (Marzano, 2003). Researchers from the 1970s to today (Edmonds, 1979; Edmonds, 1981; Levine \& Lezotte, 1990; Sammons, 1999; Marzano, 2000) all identify strong administrative leader- 
ship as a key element to student achievement and overall school effectiveness. Though they may all use slightly different terms, the factors they describe are all aspects of a strong curriculum along with challenging goals, high expectations, and effective feedback being critical in positively affecting student achievement.

Focusing on what Marzano states as the two most important factors, the principal must work with teachers to identify "essential versus supplemental content and ensure that the essential content is sequenced appropriately and can be adequately addressed in the instructional time available" (Marzano, 2003, p. 34). When the teacher uses the instructional time to focus at the heart of the curriculum, student achievement is positively affected. The principal must lead the teachers in ensuring a guaranteed and viable curriculum school-wide. One way to provide this leadership is through the teacher evaluation process (Danielson, 2008). In having high expectations, challenging goals and providing effective feedback throughout the evaluation process, the principal works with the teachers to establish academic goals both for themselves and for the school (Marzano, 2003). The principal provides timely, specific, and informative feedback to teachers to enhance instruction for increased student achievement (Marzano, 2003).

In terms of teacher-level factors, Marzano (2003) states instructional strategies, classroom management, and classroom curriculum design as being the most important factors in positively affecting student achievement. The principal, as instructional leader, must work with teachers to increase their knowledge and appropriate implementation of effective research-based instructional strategies (Danielson, 2008). Incorporating these instructional strategies with an effective classroom management system creates a safe environment conducive to student learning. Classroom management includes establish- 
ing and enforcing rules and procedures; disciplinary interventions that are a balance between both positive reinforcements and negative consequences; and establishing appropriate relationships with students that entail an "emotional objectivity toward students" (Marzano, 2003, p. 105). Finally, the classroom curriculum design is the third teacherlevel factor positively affecting student achievement. The classroom curriculum design is the "sequencing and pacing of content along with the experiences students have with that content" (Marzano, 2003, p. 106). Throughout the evaluation process, the principal must guide teachers in making classroom-level decisions on curricular design based on the needs of the current students (Danielson, 2008). Student achievement is enhanced when the content and method of the curriculum is taught with focus, student engagement, and exposure to multiple and complex methods of learning (Marzano, 2003).

\section{Conclusion}

The leadership behaviors and skill development of a principal directly relate to his/her ability in performing teacher evaluations for increased student achievement (Marzano et al., 2003). Principals influence the educational programming of students and must work with teachers to improve student achievement through goal setting, data analysis, and continual professional development. These areas are identified, discussed, and assessed during the teacher evaluation process. The principal's specific leadership behavior sets the school-wide tone for continual reflection and growth of teachers (Danielson, 2008). Effective principals must be the lead learners in schools by continuously reading, forecasting predictable scenarios, and analyzing data to assess possibilities for school-wide improvement in student achievement (National Association of Elementary School Principals [NAESP], 2008 p. 12). 


\section{CHAPTER IV}

\section{METHODOLOGY}

The primary methodologies used in this dissertation were a basic histography, including legal research, document analysis, and policy analysis. To control bias, steps were taken to ensure a variety of data was secured. The data were secured through primary sources in an attempt to ensure reliability and validity. Legal research was secured through court records and legal documents. Data on specific documents and policies were secured primarily through the U.S. Department of Education, Illinois State Board of Education, Iowa Department of Education, Rhode Island Department of Elementary and Secondary Education, and individual state legislature department records.

\section{Legal Research}

To some extent, the phrase legal research lacks a universal definition.

Traditionally, legal research has been applied to the activity of scholarship and writing undertaken almost exclusively by academic lawyers. More recently it has been used to describe the skill students need to acquire as part of their degree and professional studies and eventually employ when in legal practice. (Higher Education Academy, 2010, para. 2)

Beginning level legal research, as taught in United States' law schools, went under the curricular name of Legal Bibliography and was concerned primarily with teaching law students how to use a legal library (Higher Education Academy, 2010). Legal research, however, is much more than the technical ability to accurately use legal reporters and digests, keyword systems, cite cases, and check for currency, both in hard copy and through technology. As used in this dissertation, legal research encompasses the typical 
legal bibliography skills along with the ability to read and analyze cases, extracting the relevant points of law, applying those ideas to the problem at hand, and communicating the findings. It also includes statutory review using accepted methods such as the Mischief Rule (what was the common law before the enactment of the statute, what defect in the common law was the legislature trying to rectify, and what was the motive for the change), the Golden Rule (take the statute as a whole and give the words their ordinary meaning unless to do so would be absurd and therefore unlikely the meaning intended by the enacting body), the Literal Rule, and the Plain Meaning rule (assume that the enacting body intentionally chose its words, and meant what it said) (Higher Education Academy, 2010). The legal sources used in this dissertation were legal cases, as well as state and federal statutes.

\section{Document Analysis}

Document analysis methodology encompasses research, which uses primary documents as the data for a given study. To be valid and reliable, certain processes need to be followed by the researcher doing the analysis. First, the authenticity of the document must be verified. Usually this is not difficult, as the document is found within a context (e.g., a university library or library data base, a government office or governmental data bases). Occasionally, however, reliability of the document is in question. In such cases the researcher must be able to ascertain the origin of the document: external to the focus of the content or internally generated. In the present study, the documents examined included legislative records, government documents, and government publications (Higher Education Academy, 2010). The probability of a need for additional validation of the documents was not anticipated. 


\section{Policy Analysis}

Policy analysis was the primary methodology used in this dissertation, since the focus of this study was to provide policy recommendations for possible educational reform in Illinois. Policy analysis entails the steps of:

- defining the problem

- assembling data

- considering alternatives

- selecting the criteria

- undergoing a cost/benefit analysis

- and providing recommendations (Higher Education Academy, 2010)

In defining the problem, the first step is to determine what is it about education that warrants it being defined as a public problem and therefore rightfully addressed by public policy? One could examine documents such as Jefferson's writings on his belief "that democracy cannot long exist without enlightenment" through an educated citizenry (Archiving Early America, 2010, para. 8, sec. 1) or conduct legal research on state constitutions, which have assumed a duty to provide a public education. Next, one must ask, what about education is the problem? Perhaps it is a perceived lack of student achievement or lack of accountability of teachers, administrators, districts and states. The final step in defining the problem is to ask, what is causing the problem? Is it poor educational structure, whence the decades of federal educational reforms? Is it a failure or curriculum or assessment, whence the increasing focuses of educational administration programming on leadership, especially instructional leadership and leadership for change?

Once the problem has been defined, data, information and evidence must be collected. Data are actual facts. This includes not only statistical facts, but also the information contained in documents. Conducting document analysis and legal research is 
the collection of data (Higher Education Academy, 2010). Information is a type of data, which can be used to organize and categorize, for example federal reforms, state reforms, statutory law or common law. Finally, evidence is information that is persuasive and works to convince others that your solution to the problem is the best, or one of the best, options. Evidence includes assessing the nature and extent of the problem, the particular features of the problem, and the success and failure of past attempts at policy resolution. This entails the review of past policies, laws, leadership literature and best practices.

The third step of policy analysis, and to some extent included in the collection of evidence, is to construct other possible alternatives. For this dissertation such alternatives might include policy to increase funding either through tax increases or additional grants and subsidies, enactment of additional regulations, increase of educational alternative/ choice, modification of the current educational structure, and/or modification in the manner in which educators are trained. When considering these options, as well as possible policy recommendation arising from the study, the research needs to consider a broad area of evaluative criteria. This would include a basic cost/benefit analysis, to the legality of possible recommendations, to the political viability of the alternatives given societal values such as free market versus governmental control, educational equality and social justice. A final concern is simply administrative efficacy: can the recommendations and/or the alternatives realistically be implemented?

The researcher acknowledges that a policy analysis dissertation is not the type of dissertation that is traditionally pursued in the area of educational administration. Unfortunately, policy analysis dissertations contain a certain lack of methodological specificity when compared to the description of quantitative or qualitative methodology. 
By the very nature of the methodologies being used in this dissertation, the review of one document caused others to be uncovered, which in return raised a new set of questions not previously anticipated. In this dissertation, instead of a finite amount of numerical data included in the results of a survey, the data was contained in an almost infinite number of libraries and databases and was systematically reviewed. Therefore, other than the state chosen to represent best practices, this methodology only outlines the approach that was used and the types of data that were pursued.

\section{Quantitative Analysis}

Though not used as a primary method of analyzing data, a portion of qualitative data is analyzed in the form of statistical comparisons. In this qualitative data analysis, a variety of statistical sources are used to show comparisons of state policies and student achievement sources. Specific comparisons between the states of Illinois and Iowa were used to identify a relationship between principal accountability policies and student achievement. This portion of qualitative data is analyzed and placed in charts for reader clarity. Steps were taken to ensure validity and reliability through use of original documents, document replication secured electronically, and primary research study results. 


\section{CHAPTER V \\ RESULTS AND ANALYSIS}

\section{State Policies}

Since teacher and leadership accountability specifically appeared in educational reform beginning with the No Child Left Behind Act of 2001, both Iowa and Illinois have made adjustments or additions to state policy changes. Analyzing these policy changes, what are the strengths and weaknesses of principal accountability in teacher evaluation as it relates to student achievement in the states of Illinois and Iowa? This chapter takes a brief historical walk on how each state arrived at the current policies and codes related to principal accountability in teacher evaluation to affect student achievement.

\section{Illinois Policy}

Since A Nation At Risk was released, the state of Illinois has undergone educational reform initiatives. In 1985, the state committed to reforming curricula as the Illinois State Board of Education (ISBE) established 34 learning goals in six learning areas (Baker et al., 1997). Throughout this process, local school districts developed learning objectives to pair with the learning goals the state created. Along with these goals and objectives, each district was responsible for creating both a learning assessment plan (LAP) and a school improvement plan (SIP) (Baker et al., 1997). The purpose was to align district curriculum and assess student abilities to meet or exceed the learning goals created by ISBE. The plan to have the 
LAP and SIP filed at the state office quickly became unrealistic and burdensome (Baker et al., 1997). Instead, local school districts were to keep these plans in a file, with a letter of assurance sent to the State Superintendent of Schools. This letter states the school district had complied with procedures (Baker et al., 1997). By 1990 , these plans were not showing significant interest in school improvement and in an effort to hold schools accountable for school improvement, the state moved to implementing the Illinois Public School Accreditation Process (Baker et al,, 1997). Members throughout the state were identified to serve on Quality Review teams that would visit various public school districts in an attempt to measure accountability in school improvement planning. In a study conducted by faculty associates and graduate students at Illinois State University, feedback was given on whether teachers and principals felt the accreditation process "ignited local commitment to make significant educational change" (Baker et al., 1997, p. 3). Results from this study indicated that both principals and teachers felt the reform effort was an imposition; and that the state policies and mandates of the accreditation process did not lead to substantial school improvements or student achievement (Baker et al., 1997). The state of Illinois worked to make changes to this reform effort. The state terminated Quality Review visits and initiated peer review visits in 1997. Due, in part, to the increased accountability measures of NCLB and state testing, this process was eliminated by the state board of education (Baker et al., 1997).

The state has attempted school-wide accountability in reform efforts since A Nation At Risk. State policies are now examined on teacher and principal specific certification, tenure, mentoring, and evaluation procedures to see if accountability 
measures are in place throughout the state of Illinois.

\section{Continued Contractual Service}

Probationary period. Illinois' school code for contractual continued service (ILCS 5/24-11) states that any teacher hired prior to January 1, 1998, and who remains in that school district for two consecutive school terms enters into contractual continued service with that same school district. In 1998, this code was amended to raise the number of years for anyone hired after January 1, 1998, in any one district to a probationary period of four consecutive school terms before entering into contractual continued service. This probationary period leading to contractual continued service is in effect for teachers who are full-time employees of the district. To qualify as a 1-year term, fulltime employment must begin by the first of November and continue until the end of the school year. Once teachers have completed this 4-year probationary period, they are granted tenure status, or contractual continued service on the first day of the fifth year of employment. In 2010, the Illinois Senate passed Senate Bill 123 which reduces the probationary period back to 2 years for teachers who had previously received tenure in one district but moved to another school district. The bill was sent to the House of Representatives but had not received a vote by the end of the $96^{\text {th }}$ General Assembly. The status of this bill, as of January 2011, is listed as in the "House Rules Committee" (IEA, 2011).

Dismissal. Currently, dismissal of a teacher on the 4-year probationary period requires a written notice of at least 45 days prior to the end of the school term (ILCS, 2008). This written notice must be mailed and either delivered via certified mail, with receipt recommended, or hand deliver to the teacher in person. If a teacher reaches the 
end of the 4-year probationary period and has not been given a written notice of dismissal 45 days prior to the end of the school term, that teacher is automatically entered into contractual continued service with that school district. This is one noted measure of principal accountability in the state code. It is the principal's responsibility to make sure the 45-day written notice is given in the manner addressed in this code. It is also the responsibility of the principal to make a decision to recommend to the superintendent that a teacher not be renewed. It is the responsibility of the school board to follow through with the dismissal recommendation from the superintendent.

In addition to the state code of promoting or dismissing a teacher prior to receiving tenured status, the state code provided provisions for school districts to follow regarding teachers who are tenured or under contractual continued service. If a teacher is tenured or on contractual continued service and the district either decides to reduce the number of teachers or dissolves a program, that teacher is eligible for a position elsewhere in the district. The teacher must be qualified for the specific position. In these instances, seniority of district teachers takes precedence unless there are different provisions in the negotiated agreement. If a program dissolves and the tenured teacher does not have seniority over any other teacher in the area for which they are qualified to teach, the district may provide an honorable dismissal. To dismiss in this manner, the district must provide a written notice, by seniority, at least 60 days prior to the end of the school term. This written notice must be mailed and either delivered via certified mail or hand delivered to the teacher in person. If a position opens within the next 2 calendar years in which the dismissed teacher is qualified for, that teacher has the option of accepting that job within the school district. 
If the board has any vacancies for the following school term or within 2 calendar years from the beginning of the following school term, the positions so becoming available shall be tendered to the teachers who were so notified and removed or dismissed whenever they are legally qualified to hold such positions. (ILCS, 2008, p. 531)

Other reasons for dismissing a teacher already under tenure or contractual continued service include incompetency, cruelty, negligence, or immorality. Another reason is if the teacher fails to complete a 1-year remediation with a satisfactory rating or better. Temporary mental or physical incapacity to perform duties is not cause for dismissal (ILCS, 2008). To dismiss in any of these fashions, the board of education must "approve a motion containing specific charges by a majority vote with all its members" (ILCS, 2008, p. 531). Written notice must be given within 5 days of the motion adoption.

\section{Evaluation Code}

Along with the state codes on contractual continued service criteria, a specific code exists on conducting evaluations of certified staff throughout the school district. The Illinois school code on evaluations is listed under ILCS Article 24A.

The purpose of this Article is to improve the educational services of the elementary and secondary public schools of Illinois by requiring that all certified school district employees be evaluated on a periodic basis and that the evaluations result in remedial action being taken when deemed necessary. (ILCS, 2008, p. 536)

Accountability lies with the school principal to ensure evaluations of certified staff in the school building are conducted according to state policies. To ensure principals effectively evaluate certified staff, ILCS 5/24A-3 focuses on evaluation training. This code requires school administrators, whose duties include evaluation of certified staff, to participate in a state approved evaluator training at least once every 5 years (ILCS, 2008). Beginning September 1, 2012, an evaluator performing evaluations on certified staff must 
successfully complete a "pre-qualification program provided or approved by the State Board of Education" (Illinois General Assembly, 2011, para. 13). The program must consist of "rigorous training and an independent observer's determination that the evaluator's ratings properly align to the requirements established by the State Board" (Illinois General Assembly, 2011, para. 13). Prior to 1992, the school code provided only the requirement of the evaluation workshop. The school improvement section was added in the 1992 amendment. In the state of Illinois, workshops that qualify under this regulation are titled Administrator Academies. In order to renew your administrative certificate in the state of Illinois, administrators must participate in at least one Administrator Academy each calendar year (ILCS, 2008). The Illinois State Board of Education (ISBE) holds administrators accountable to this requirement through the Educator Certification System (ECS). The Educator Certification System is a data management system that tracks Continuing Professional Development Units (CPDU) for all educators. Administrators are responsible for inputting annual Administrative Academies into the system and keeping track of documentation that proves they complied with requirements (ILCS, 2008). In this same manner, all teachers in the state of Illinois must input evidence and keep proper documentation on individual CPDU credits as they work to renew their teaching certificate every 5 years.

Under ILCS 5/24A-4, all school districts in Illinois must develop, in cooperation with bargaining representatives, an evaluation plan for all teachers in contractual continued service. No later than October 1, 1986, school districts were required to submit district evaluation plans. These plans were to be reviewed and made viewable to the public by the Illinois State Board of Education (ISBE). If the evaluation plan substantially 
changes at any time, districts must resubmit these plans to ISBE. The content of the evaluation plan and the criteria for evaluation are listed in the state code as well. Until fall 2010, when the state of Illinois amended current policy, the evaluation plan was to include descriptions of teacher "duties and responsibilities and the standards to which that teacher is expected to conform" (ILCS, 2008, p. 537). The evaluation was to include at least a personal observation of the teacher in a classroom setting. The qualified administrator was to include "consideration of the teacher's attendance, planning, and instructional methods, classroom management, where relevant, and competency in the subject matter taught, where relevant" (ILCS, 2008, p. 537). A rating of performance as excellent, satisfactory, or unsatisfactory was to be included, along with teacher strengths and weaknesses, supported by reasons for the comments written. A copy of the final written evaluation must be given to the teacher and another copy placed in the teacher's personnel file. Components of this policy were amended in 2010 and are discussed later in this chapter.

Teachers who are still in the 4-year probationary period must receive a formal written evaluation by a certified administrator at least once every year of the probationary period. Teachers already in tenured status must receive one evaluation every 2 years. If a teacher is rated unsatisfactory, a remediation plan must be developed within 30 days after completion of the written evaluation. The remediation plan consists of a 90 -day period, with evaluations once every 30 school days for that remediation timeframe. A consulting teacher with at least 5 years of experience and who has received an excellent rating in their recent evaluation is to be provided to the teacher in remediation as a mentor for teacher improvement. If the teacher on remediation receives at least a 
satisfactory rating by the evaluator at the end of the 90 -day remediation period, the teacher returns to the evaluation schedule of once every 2 years. If the teacher receives an unsatisfactory rating at the conclusion of the 90-day remediation period, the district may move for dismissal where a hearing officer will be provided by the school board.

\section{0-2011 Policy Amendments}

In an attempt to meet Race to the Top program funds, a new evaluation law was passed by Illinois in the fall of 2010. In this new evaluation law, certain conditions are negotiable by bargaining units in individual school districts (IEA, 2010). Other terms are unconditional and are now state policy. One of the unconditional terms is the prohibiting on the disclosure of evaluations for teachers, principals, and superintendents. The other areas of the law that are unconditional are to be put in place no later than September 1, 2012, and include the following:

- Probationary teachers must be evaluated at least once every year;

- Evaluation plans for tenured teachers must include four rating categories (excellent, proficient, needs improvement, and unsatisfactory);

- Tenured teachers rated as 'needs improvement' must be evaluated at least once in the following school year;

- Tenured teachers who receive a rating of 'needs improvement' must have a professional development plan created, within 30 school days, that details the areas needing improvement and a list of what supports the district will provide in the same areas;

- Tenured teachers who receive an 'unsatisfactory' rating must be placed on a remediation plan, with mid-point (approximately 45 school days) and final (at the end of 90 school days) evaluations conducted;

- During a remediation period for a tenured teacher, a written evaluation detailing deficient areas of performance and recommendations for improvement must be provided and discussed within 10 days, unless the collective bargaining contract states differently; and

- During the remediation period for a tenured teacher, a final evaluation must include on overall evaluation of the teacher's performance. (IEA, 2010) 


\section{Mentoring Programs}

In 2003, Illinois initiated a new teacher induction and mentoring program (ILCS $5 / 21 \mathrm{~A}, 2008)$. It required all schools in Illinois to have an induction and mentoring program in place by the 2005-2006 school year. The program requires that individual school districts assign a mentor to a new teacher for 2 years. The program is required to be aligned to the Illinois Professional Teaching Standards. Professional development must be provided to the new teacher. A formative assessment must be conducted to provide feedback and reflection to the new teacher during this 2-year mentor program.

Two additional mentoring programs in Illinois are the Superintendent Mentoring Program and the Principal Mentoring Program (ILCS, 2010). The Superintendent Mentoring Program Act requires that any superintendent who has never served in this capacity before and starts on or after July 1, 2009, must participate in a 2-year mentoring program established by the Illinois State Board of Education (ISBE). The program entails matching a new superintendent with a superintendent who has served in Illinois for at least 3 years and has demonstrated success as an instructional leader (ILCS, 2010). House Bill 737, the Principal Mentoring Program Act provides for a 1-year principal mentoring program (ILCS, 2010). In the spring of 2010, House Bill 737 advanced for further approval, states that principals hired after July 1, 2008, are eligible to participate in a second year of mentoring through the new principal mentoring program. The amendment to this bill removes the progress survey, provides the option for mentoring of master level principals, and suggests another name for the Master Principal Designation program as the Illinois Distinguished Principal Leadership Institute (ISBE, 2010). 


\section{Accountability}

The Illinois School Code has established an accountability measure in the form of an evaluation for principals as well. The Principal Evaluation Law, enacted in 2006 requires the district superintendent to complete an evaluation of the principal by March $1^{\text {st }}$ of the final year of the principal's employment contract. The Performance Evaluation Reform Act of 2010 was enacted because "effective teachers and school leaders are a critical factor contributing to student achievement" (Illinois General Assembly, 2010, para. 3). The General Assembly of Illinois stated that performance evaluation systems should accurately assess both the professional competencies of principals and student achievement growth. Outside of the specified deadlines for completion, the principal's evaluation is to include:

- duties;

- responsibilities;

- management;

- competency as a principal with supporting reasons for noted strengths and weaknesses; and

- align with either the Illinois Professional Standards for School Leaders or other research-based standards. (ILCS, 2010)

The principal must be evaluated once every year. If the superintendent or designee does not evaluate the principal in the allotted timeframe, the principal's contract is automatically extended for another year term. Accountability is mentioned in the various state codes but specific measures of these evaluation expectations are not specified.

As the 2010 calendar year came to a close, Illinois legislators either passed or proposed draft legislation that would change current policies and codes in the areas of reporting student achievement, educator certificates, principal autonomy, tenure, dismissal procedures, evaluation, and labor relations (State School News, 2011). These proposed 
changes would be called the Performance Counts Act of 2010 (State School News, 2010). Specific areas of this drafted legislation that relate to principal accountability in the evaluation of teachers as it relates to student achievement are in the areas of principal autonomy, tenure, dismissal procedures, and evaluation. In this drafted legislation, the Performance Evaluation Reform Act passed in 2009 would be a decisive factor in teacher assignments and dismissal of teachers deemed incompetent. Principal Autonomy (24-1) proposes teacher assignments be filled based on merit and not seniority. The probationary period for teachers to receive tenure status (24-11) remains at 4 consecutive years in one school district, with four consecutive evaluation ratings of satisfactory, proficient, or excellent. Dismissal on the basis of teacher performance (24-12b) lowers what a teacher is required to be given in the dismissal proceedings. These changes include:

- Dismissal notice must be given within 90 days of the last evaluation;

- The teacher has 10 days to appeal the dismissal;

- The teacher must demonstrate that the performance evaluation results are not valid or appropriate;

- The superintendent convenes a hearing in front of a panel consisting of designees of the superintendent, teachers or teachers' union, and a school board member;

- The Illinois State Board of Education presides over the hearing, allowing the teacher only one day to provide necessary evidence and testimony of unfair dismissal;

- The superintendent provides the school board the panel's findings of the hearing within 30 days;

- If the panel's findings are for the teacher to be placed on probationary status, the probationary status is in effect for at least one full school term, not subject to judicial review; and

- The Administrative Review Law applies to all dismissal hearings and not through the circuit court, unless the decision of the board is found to be arbitrary, capricious, discretionary abuse, or unlawful. (School State News, 2011) 


\section{Iowa Policy}

The state of Iowa also has teacher and principal specific state policies on contractual service, evaluation, training, and mentoring.

\section{Path to Continued Contractual Service}

The Iowa Beginning Teacher Mentoring and Induction Program (Section 284.4) specifies the promotion path for beginning teachers in Iowa. The path to contractual continued service in Iowa involves a teacher mentoring and induction program, developed by each school district, to "promote excellence in teaching, enhance student achievement, build a supportive environment within school districts and area education agencies, increase the retention of promising beginning teachers, and promote the personal and professional well-being of teachers" (Iowa Code, 2010, section 1). During this 2-year induction, Iowa teachers receive an initial license. The induction process involves a comprehensive evaluation to determine if the teacher meets the expectation to progress along the career path/levels. A beginning teacher who successfully shows competency is recommended for a standard license. If the teacher does not show competency, the board can recommend a third year of induction for a specific teacher. If a teacher is granted a third year of induction, the teacher must create a mentoring and induction program plan and undergo another comprehensive program evaluation (Iowa Code, 2010). For teachers who move from one district to another during this 2-year induction phase, the hiring district is required to "credit the beginning teacher with the time earned in the program prior" (Iowa Code, 2010, section 7). As teachers progress along the career path, they are promoted one level at a time, requiring at least 1 year in movement between levels. The levels include: Beginning Teacher, Career Teacher, 
Career II Teacher, and Advanced Teacher. In addition to the evaluation criteria, under state code 284.6, Teacher Professional Development, the teacher's evaluator must meet with the teacher to review progress on individual goals. These individual plans must relate to the school improvement plans. The teacher is responsible for showing evidence of progress on stated goals.

\section{Teacher Evaluation and Principal Accountability}

The state of Iowa has worked on implementing effective education reform to bring principal accountability in teacher evaluations as it relates to student achievement. One of the noted reform efforts was the 2002 Iowa Code 284.3 , the integration of statewide Iowa Teaching Standards (ITS). An accompanying statewide teacher evaluation system through the Iowa Evaluator Approval Training Program (IEATP) was also integrated. In the state of Iowa, part of the teaching standards include provisions for the board of education to ensure specific criteria are met on comprehensive evaluations for teachers. Focusing on Chapter 284: Teacher Performance, the code provides a detailed description of criteria for teacher advancement.

\section{Evaluation Code}

In the state of Iowa, the teacher evaluation system must support and be aligned to the Iowa Teaching Standards (Iowa Code, 2010). Local school districts must determine what "policies, procedures and processes are needed to support Iowa Teaching Standards and Criteria" (DE, 2011, section 1). The state has specific guidelines regarding evaluation plans for teachers. Local teacher evaluation plans must be developed by the local school districts, encompassing the following criteria: 
- use of the Iowa teaching standards and criteria;

- comprehensive evaluation of beginning teachers that includes a review of the teacher's progress on the Iowa teaching standards and the use of the Department of Education's comprehensive evaluation instrument;

- performance reviews of career teachers need to be conducted once every 3 years and include classroom observation of the teacher, a review of the teachers progress on the Iowa teaching standards and additional standards and criteria, a review of the implementation of teacher's individual professional development plan, and supporting documentation from other evaluators, teachers, parents, and students. (DE, 2011, para. 2)

\section{Career Path}

Section 284.3, entitled Iowa Teaching Standards, addresses the evaluation of beginning level teachers and teachers in all other levels (Iowa Code, 2010). Iowa teachers progress along a path from Beginning Teacher to Career Teacher. According to Iowa code 279.14, Evaluation Criteria \& Procedures, provisions are expected to be negotiated between individual school boards and bargaining representatives. In the development of teacher evaluation criteria, the Iowa Teaching Standards include the teacher's demonstration of his or her

- ability to enhance academic performance;

- competency in content knowledge, planning and preparing for instruction;

- use of strategies that meet multiple learning needs of students;

- monitoring student learning;

- competency in classroom management;

- engage in professional growth; and

- fulfill professional responsibilities noted by the school district. (Iowa Code, 2010)

The performance review of a teacher who is not classified as beginning must entail at least the criteria from the Iowa Teaching Standards listed above. These standards define the characteristics of quality teaching. The school board and the collective bargaining group negotiate the criteria specified in this performance review. In Section 
284.4 , Iowa school districts are eligible for grant money if they agree to create a teacher quality committee. This committee is to be an equal representation of teachers and administrators. The responsibilities of the committee include monitoring the evaluation requirements "to ensure evaluations are conducted in a fair and consistent manner" (Iowa Code, 2010, section 2). Professional development is to be monitored to ensure it meets district and personnel professional development plans (Iowa Code, 2010). In addition, this committee is responsible for adopting a teacher evaluation plan that requires at least a performance review of teachers once every 3 years. This plan must be based on both the Iowa Teaching Standards and the individual professional growth plans of the teacher (Iowa Code, 2010). Iowa Code 284.8 explains that the purpose of this evaluation is to assist teachers in continuous improvement, "documenting continued competency in the Iowa Teaching Standards, identifying teachers in need of improvement, or to determine whether a teacher's practice meets school district expectations for career advancement" (Iowa Code, 2010, section 1). If an administrator determines a teacher is not meeting district expectations, the evaluator is expected to recommend the teacher participate in an intensive assistance program (Iowa Code, 2010). If a teacher, due to the performance review, is denied advancement to Career II or Advanced levels, the teacher may appeal the decision to an adjudicator. The decision of the adjudicator becomes final.

\section{Administrator Training}

Prior to any administrator conducting performance reviews, the evaluator must participate in the Iowa Evaluator Approval training program (DE, 2011). Iowa Code 284.10 discusses the training required of school administrators to improve his/her skills in the areas of employment decisions, licensure recommendations, and criteria for 
moving teachers through the Iowa career path (Iowa Legislature, 2011). This training must be renewed every 5 years. The training program entails three levels. Level one is the initial training, extending 6 days. Participants are required to complete a selection of activities that include training in data and teacher observation (DE, 2011). Level two is the renewal training, requiring 5 days of formal training, focusing on teacher conferences in the evaluation process. The third level of training is on "assessing academic rigor" (DE, 2011, para. 8), as well as an additional course of the administrator's choice related to leadership in teacher evaluation. At each level, participants receive licensure credits that collectively lead to requirements for administrative certificate renewal (DE, 2011).

Iowa Leadership Academy. The Iowa Leadership Academy (ILA) was developed to support principals and superintendents across the state. The Principal Center of the academy was created in June of 2007 by statewide principals to support quality leaders (DE, 2011). The mission of the Principal Center of the Iowa Leadership Academy is to "create a community where school leaders discover their skills, their wisdom and their passion for leading learning" (DE, 2011, para. 2). This voluntary participation allows principals throughout the state to continue personal growth in linking leadership and learning through networking, collaborating, coaching, action plans, and goal setting (DE, 2011).

Principal evaluation and accountability. In addition to teacher quality programs and review, Iowa Code 284.A.1 speaks about the Administrator Quality Program development. The Administrator Quality Program focuses on three major components:

- mentoring and induction programs that provide support for administrators;

- professional development designed to directly support best practices for leadership; and 
- evaluation of administrators against the Iowa Standards for School Administrators. (Iowa Code, 2010)

Effective July 1, 2008, each school board must provide evaluations for administrators under individual professional development plans and the Iowa standards. Effective July 1,2007 , each school district must participate in an administrator quality program by implementing a Beginning Administrator Mentoring Program. Each school district must adopt individual professional development plans as well as an evaluation plan that requires an annual administrator evaluation based on the standards and individualized professional development plans (Iowa Code, 2010). At the end of the first year for a beginning administrator, the school district recommends either dismissal, a second year on the mentoring and induction plan, or movement to a standard administrator licensure. The evaluation requirements for administrators are listed under Iowa Code 284A.7, Evaluation Requirements for Admin-istrators (Iowa Code, 2010). Once a beginning administrator moves to a standard license, they are evaluated at least once every 3 years. The purpose of the evaluation is ensuring continuous improvement, documenting competency in the Iowa standards, and progressing toward their individual professional development plan. Other than noting what the responsibilities of teachers, administrators, and school boards are in terms of evaluation and continued employment, no specific provisions on mandated accountability measures were found.

In a survey study conducted by Lasswell, Pace, and Reed (2008), Iowa principals were asked what they thought about the implementation of the Iowa Teaching Standards and the teacher evaluation system. Did the Iowa Teaching Standards change the way principals conducted teacher evaluations (Lasswell et al., 2008)? This study found that approximately two-thirds of the principals surveyed claimed the incorporation of the 
Iowa Teaching Standards and Iowa Evaluator Approval Training Program improved their individual skills and methods in the teacher evaluation process (Lasswell et al., 2008). Believing these measures improved principal skill is one area of importance. Another important area is whether the standards and evaluator training affected student achievement. A brief review of Iowa student achievement scores for fourth graders shows overall reading proficiency scores in 1999 to be in the $67^{\text {th }}$ percentile with student achievement data from 2008 showing overall student reading proficiency scores in the fourth grade to be in the $78^{\text {th }}$ percentile. Many factors could be attributing to this increase, one being the enactment of Iowa Code 284.3 (Results Iowa, 2008).

In addition to state achievement scores, the Regional Educational Laboratory Technical Brief released in July of 2008 comparing state policies on teacher evaluation practices in the Midwest region. In the area of addressing characteristics of teacher evaluation within each state, Iowa was found to have met 11 of the 13 specified characteristics. These characteristics of teacher evaluation included specifics in the three main areas of

- teacher evaluation standards and criteria of teacher practice or performance;

- different evaluation policies for content areas and special populations; and

- communication of evaluation policy to teachers. (NCEERA, 2008, p. 2)

Education reform in Iowa has included a focus on principal accountability in the evaluation of teachers as it relates to student achievement. Lasswell et al. (2008) claim that evaluators in Iowa continually work to "improve student achievement in an environment in which local control is nearly sacred, yet defining what good teaching looks and sounds like and, of course, how to recognize it" (Lasswell et al., 2008, p. 43). 


\section{Overall State Policy Strengths and Weaknesses}

A personal analysis of each state's policies on principal accountability in the evaluation of teachers as it relates to student achievement finds weaknesses. Though both states have policies that include the training of principals in the evaluation of teachers, along with a specified number of times teachers are to be evaluated, neither state has a policy of 'checks and balances.' No provisions are in place to ensure principals are following through with these state policies on teacher evaluation. The attempts in both states to ensure principals are effectively trained in evaluation include varying levels of professional development. The state of Illinois requires an evaluating administrator to be trained in teacher evaluation once every 5 years, until September 1, 2012, when the training completion requirements are enhanced. The state of Iowa requires a uniform state-wide training for administrators that entails three levels of professional development. At each level, a certain number of training days or hours are specified. Iowa policy requires a uniform and comprehensive teacher evaluation form for teachers in the beginning level of teaching. Both states have a policy requiring an evaluation to be performed on principals specific to leadership standards. The primary weakness found in the Iowa policies on principal accountability for teacher evaluation is that the statewide effort to provide uniform training and a uniform evaluation form have not yet shown a significant affect on student achievement based on current statewide student assessment results. State test results show only a small percentage increase in student performance in the last decade.

Analysis of both states shows an inability throughout state policies to provide specific requirements on what effective feedback for the evaluation of teachers must 
entail as it relates to student achievement. "An evaluation process must have meaningful implications, both positive and negative, in order to earn sustained support from teachers and school leaders and to contribute to the systemic improvement of the teacher workforce" (The New Teacher Project, 2010).

\section{National Council on Teacher Quality (NCTQ) Report}

Additional strengths and weaknesses of individual state reform efforts are highlighted in individual state policies through the biennial report from the National Council on Teacher Quality (NCTQ). The release of a State Teacher Policy Yearbook, details grades given to states based on five areas of teacher evaluation and preparation (NCTQ, 2011). The five areas are:

- delivery of well prepared teachers;

- expanding the teaching pool;

- identifying effective teachers;

- retaining effective teachers; and

- exiting ineffective teachers. (NCTQ, 2011)

Along with providing each state a grade in these five areas, the NCTQ provides recommendations to state policymakers on how to strengthen state policy to have a positive impact on teacher evaluation that ultimately affect student achievement. In the 2009 Yearbook, Illinois was given an overall grade of $\mathrm{D}+$ and Iowa was given a grade of $\mathrm{D}$ (NCTQ, 2010). Table 2 shows the state comparison.

Table 2

2009 NCTQ State Teacher Policy Yearbook Grades

\begin{tabular}{lccccc}
\hline State & $\begin{array}{c}\text { Delivery of } \\
\text { Well Prepared } \\
\text { Teachers }\end{array}$ & $\begin{array}{c}\text { Expanding } \\
\text { the Teaching } \\
\text { Pool }\end{array}$ & $\begin{array}{c}\text { Identifying } \\
\text { Effective } \\
\text { Teachers }\end{array}$ & $\begin{array}{c}\text { Retaining } \\
\text { Effective } \\
\text { Teachers }\end{array}$ & $\begin{array}{c}\text { Exiting } \\
\text { Ineffective } \\
\text { Teachers }\end{array}$ \\
\hline Illinois & $\mathrm{D}$ & $\mathrm{D}+$ & $\mathrm{D}$ & $\mathrm{D}$ & $\mathrm{B}$ \\
Iowa & $\mathrm{D}$ & $\mathrm{D}$ & $\mathrm{D}$ & $\mathrm{C}-$ & $\mathrm{D}+$ \\
\hline
\end{tabular}


In the 2010 yearbook report, no grades were given to individual states. Instead, the committee provided a state-by-state update on the positive and negative progress on goals and actions taken in the past year to develop stronger policies on teacher evaluation, tenure, and dismissal (NCTQ, 2011). The committee noted most of these changes were directly related to the incentives of the federal Race to the Top program. Part of the incentive program requires drastic changes in state policy. The purpose of the 2010 report was to provide guidance to state policymakers as they continue to analyze and make changes to current state policy (NCTQ, 2011).

The results of this study from NCTQ must be shared with hesitation. The American Association of Colleges of Teacher Education (AACTE) has identified several flaws in the research conducted by NCTQ. These flaws in research include:

- the simplistic manner in which data were selected and analyzed did not follow appropriate, credible research protocol;

- the recognition of many professional standards from states were not used in the review process;

- dated material was reviewed rather than the most current information;

- factual errors were not corrected in NCTQ drafts;

- the credentials and experience of NCTQ reviewers were not disclosed, which leads to credibility concerns; and

- NCTQ as a group is self-appointed, with the agenda to criticize state education systems. (AACTE, 2010)

\section{State Policy Updates}

The NCTQ identified several policies the state of Illinois had updated in regard to teacher evaluation, tenure, or teacher dismissal. From 2009 to 2010 , the state of Illinois made five changes to state policy. These changes were in the areas of teacher evaluation, teacher licensure, teacher preparation program account-ability, basic skills scores, and alternative route providers (NCTQ, 2011). Focusing on changes that would affect principal accountability in the evaluation of teachers as it relates to student achievement, 
direct policy changes to teacher evaluation are specified. In the teacher evaluation policy through Senate Bill 315, the state of Illinois now requires student growth be a significant factor in teacher evaluations. Teachers must now be rated as excellent, proficient, needs improvement, or unsatisfactory. If the local district and the bargaining units cannot come to an agreement within 180 days, the district must implement the state evaluation model. The state evaluation model requires student growth to account for $50 \%$ of the teacher's performance rating. Additional policy changes in this area are specific to the Chicago public school district, or any district with a population of 500,000 or more. If this population cannot come to an agreement within 90 days, the district is required to implement the last best proposal of a teacher model evaluation plan (NCTQ, 2011). Probationary teachers throughout the state must be evaluated once every school year and nonprobationary teachers evaluated at least once every 2 years. Any non-probationary teacher-one who is in a contractual continued service contract—who receives an evaluation rating of needs improvement or unsatisfactory must be evaluated at least once in the following school year (NCTQ, 2011).

In analyzing policy changes for the state of Iowa, no recent policy changes were identified by the NCTQ. When asked about policy updates to the state, the Iowa Department of Education explained that the state amended the state teaching standards in an effort to assist with the Race to the Top application (NCTQ, 2011). Part of this amendment now requires multiple forms of evidence to be reported on student achievement. In addition, the state strengthened its commitment to evaluate teachers using student performance data. 


\section{Additional State Comparisons}

"The more sustained and comprehensive the accountability system,...the better states' learning progress appears" (Peterson, 2003, p. 316). Individual state policies specify provisions for local school districts to follow. To account for progress and accountability, primarily in the wake of No Child Left Behind mandates, individual states report yearly student achievement data. A report released by EPE Research Center in January 2011, through the Quality Counts assessment group, explains results from several studies conducted on state comparisons in school achievement across the United States. Quality Counts is noted as "the most comprehensive ongoing assessment of the state of American education" (Education Week, 2011, para. 2). The report concluded that the entire nation received an overall grade of a $\mathrm{C}$ in performance and policy tracked areas.

Included in the overall detailed report released by Quality Counts were individual states grades and a ranking in the following areas:

- Chance-for-Success Index

- K-12 Achievement Index

- Standards, Assessments, \& Accountability

- Transitions \& Alignment

- Teaching Profession

- School Finance. (Education Week, 2011, p. 5)

Though this type of report has been released by Quality Counts for over a dozen years, 2008 marked the first year the two areas of Chance-for-Success Index and K-12 Achievement Index were included. The Chance-for-Success Index score shows how a state scores in the ability to educate a child from "cradle to career" (Education Week, 2011, p. 6). The grades indicate individual factors that include preparation in early childhood, student performance scores during school-age years, and outcomes in 
adulthood (Education Week, 2011). The K-12 Achievement Index scores individual states in three areas of student achievement:

- current levels of performance (status);

- improvement over time (change); and

- achievement gaps between poor and non-poor students (equity). (Education Week, 2011, p. 7)

\section{Student Achievement Results}

Chance-for-Success. Focusing on the strengths and weaknesses of Illinois and Iowa in student achievement, the following information explains where Illinois and Iowa rank in both areas. In 2008, the average state received a grade of $\mathrm{C}+$ in Chance-forSuccess, with Illinois receiving a grade of B- (81.3 points). This grade comprised 25.7 points in Early Foundations, 36.1 points in the School Years area, and 19.5 points in Adult Outcomes. In 2011, Illinois received an overall grade of a B- (81.4 points). This score was given by averaging the individual scores of 25 points in the Early Foundations area, 37.2 points in the School Years area, and 19.2 points in the Adult Outcomes area. With this overall score, Illinois ranked $19^{\text {th }}$ in the nation in both 2008 and 2011.

In 2008, Iowa's overall grade in Chance-for-Success was a B (83.6 points). This grade comprised 28 points in Early Foundations, 37 points in School Years, and 18.6 points in the Adult Outcomes area. This score gave Iowa a ranking of $11^{\text {th }}$ in the nation. In 2011, Iowa's overall grade in this Chance-for-Success area was slightly higher with a B (84.7 points). This score was given by averaging the individual scores of 27.9 points in the Early Foundations area, 37.5 points in the School Years area, and 19.3 points in the Adult Outcomes area. Comparing these scores, Iowa has improved slightly, currently ranking $10^{\text {th }}$ nationwide. 
K-12 Achievement. In 2008, in the area of K-12 Achievement, Illinois was given a grade of $\mathrm{D}+(69.1$ points), comprising of 25 points in status, 26.1 points in the change area, and 18 points in equity. This put Illinois at $27^{\text {th }}$ in the nation. Iowa ranked $20^{\text {th }}$, with a grade of $\mathrm{C}$ - (71.4 points). This grade comprised a status score of 26 points, change score of 26.3 points, and 19.1 points in the equity area. In K-12 Achievement, the average state scored a D+ in the 2008 report. In 2011 the achievement grade given by Quality Counts to the state of Illinois was a $\mathrm{D}+(67.7$ points). These points comprised an average of 25.6 points in current level of performance (status), 26.3 points in state improvement over time (change), and 15.8 points in the achievement gap between poor and non-poor students (equity). With this score, Illinois ranks above Iowa as $28^{\text {th }}$ across the nation in K-12 student achievement. Comparatively, Iowa received a score of 65.9 points. These points give Iowa a grade of $\mathrm{D}$ in the K-12 Student Achievement area. The individual scores of 24.7 (status) 23.4 (change) and 17.8 (equity) bring the state of Iowa to $33^{\text {rd }}$ in the nation. This score dropped Iowa significantly from the ranking of $20^{\text {th }}$ in 2008 .

Table 3 shows the individual state scores and rankings in these two areas from the 2008 Quality Counts report; and Table 4 shows the individual state grades and rankings in these same two areas from the 2011 Quality Counts report. These results show neither state is making the changes needed to cause greater improvements for increased student performance. Both states must focus efforts in the K-12 achievement area. Bridging the gap between advantaged and disadvantaged children is a struggle most states encounter (Education Week, 2011). States need to merge research theories into practice in this area. 
Table 3

Results from 2008 Quality Counts

\begin{tabular}{|c|c|c|c|c|c|c|c|}
\hline \multirow[b]{2}{*}{ State } & \multicolumn{3}{|c|}{$\begin{array}{c}\text { Overall } \\
\text { State Grade }\end{array}$} & \multicolumn{2}{|c|}{$\begin{array}{c}\text { Chance for } \\
\text { Success }\end{array}$} & \multicolumn{2}{|c|}{ K-12 Achievement } \\
\hline & Grade & Score & Rank & Grade & Rank & Grade & Rank \\
\hline Illinois & N/A & N/A & N/A & B- & 19 & $\mathrm{D}+$ & 27 \\
\hline Iowa & N/A & N/A & N/A & B & 11 & $\mathrm{C}-$ & 20 \\
\hline
\end{tabular}

Table 4

Results from 2011 Quality Counts

\begin{tabular}{|c|c|c|c|c|c|c|c|}
\hline \multirow[b]{2}{*}{ State } & \multicolumn{3}{|c|}{$\begin{array}{c}\text { Overall } \\
\text { State Grade } \\
\end{array}$} & \multicolumn{2}{|c|}{$\begin{array}{c}\text { Chance for } \\
\text { Success }\end{array}$} & \multicolumn{2}{|c|}{$\underline{\mathrm{K}}-12$ Achievement } \\
\hline & Grade & Score & Rank & Grade & Rank & Grade & Rank \\
\hline Illinois & $\mathrm{C}$ & 73 & 40 & B- & 19 & $\mathrm{D}+$ & 28 \\
\hline Iowa & $\mathrm{C}+$ & 76.7 & 26 & $\mathrm{~B}$ & 10 & $\mathrm{D}$ & 33 \\
\hline
\end{tabular}

Keeping the grades, scores, and rankings from the Quality Counts report in mind, the following examines how each state scores against national measures of student progress, as well as how students are scoring on individual state assessments.

\section{NAEP}

The NAEP is a national assessment of what students know and can do in a variety of subject areas (U.S. Department of Education, 2010). Schools across the nation are selected to participate based on representing a diverse student population, focusing on collecting data from various regions across the nation. Other factors influencing school participation include "sex, race, degree of urbanization of school location, parent 
education, and participation in the National School Lunch Program" (U.S. Department of Education, 2010, para. 2).

As Table 5 indicates, Illinois is narrowing the poverty gap in fourth grade by close to $3 \%$ and in eighth grade just under $4 \%$. Iowa is narrowing the poverty gap by a lower percentage. Though overall achievement in both states has a positive gain, perhaps the most notable areas are in the advanced measurement scores. In terms of eighth grade mathematics advanced growth, both states improved by over $2 \%$. In grades 11 and 12 , results for advanced placement show a positive change growth by $3.5 \%$ in Illinois and just under $6 \%$ in Iowa.

Table 6 shows the 2009 fourth and eighth grade scores from both Illinois and Iowa students on the National Assessment of Educational Progress (NAEP) in mathematics and reading. The table also shows the degree of growth in student achievement in the fourth, eighth, eleventh, and twelfth grades. These results indicate that although both states are lessening the poverty gap, they are not doing so at a drastic enough rate. Scores in the Advanced Placement area are increasing at a faster rate. This trend will ultimately increase the achievement gap between advantaged and disadvantaged children if efforts are not more focused and successful in practice with disadvantaged children. 
Table 5

Illinois and Iowa NAEP Results

\begin{tabular}{|c|c|c|c|c|c|c|c|c|}
\hline \multirow[b]{3}{*}{ State/Grade } & \multicolumn{2}{|c|}{ Achievement Level } & \multicolumn{2}{|c|}{ Achievement Gains } & \multicolumn{2}{|c|}{ Poverty Gap } & \multirow{2}{*}{$\begin{array}{c}\text { Achieving } \\
\text { Excellence } \\
\\
\text { Math Advanced } \\
\text { Change } \\
(2003-2009) \\
\end{array}$} & \multirow{3}{*}{$\begin{array}{c}\begin{array}{c}\text { Advanced } \\
\text { Placement }\end{array} \\
\text { High Test } \\
\text { Scores ( } 3 \text { or above) } \\
\text { Change (2003-2009) }\end{array}$} \\
\hline & $\begin{array}{c}\text { Math } \\
\text { Proficiency } \\
\end{array}$ & $\begin{array}{l}\text { Reading } \\
\text { Proficiency }\end{array}$ & $\begin{array}{c}\text { Math } \\
\text { Change } \\
(2003-2009) \\
\end{array}$ & $\begin{array}{c}\text { Reading } \\
\text { Change } \\
(2003-2009)\end{array}$ & $\begin{array}{r}\text { Poverty } \\
(2003 \\
\end{array}$ & $\begin{array}{l}\text { hange } \\
\text { 2009) }\end{array}$ & & \\
\hline & $4^{\text {th }} \mathrm{gr} \cdot 8^{\text {th }} \mathrm{gr}$ & $4^{\text {th }}$ gr. $8^{\text {th }}$ gr. & $4^{\text {th }}$ gr. $8^{\text {th }}$ gr. & $4^{\text {th }}$ gr. $8^{\text {th }}$ gr. & $4^{\text {th }} \mathrm{gr}$. & $8^{\text {th }} \mathrm{gr}$. & $8^{\text {th }}$ grade & \\
\hline Illinois/D+ & 37.633 .1 & $32.3 \quad 32.7$ & +5.4 & +2.9 & -2.9 & -3.9 & +2.4 & +3.5 \\
\hline Iowa/D & $41.4 \quad 33.9$ & $34.2 \quad 32.2$ & +4.1 & -2.6 & -1.0 & -0.6 & +2.5 & +5.8 \\
\hline
\end{tabular}




\section{Illinois and Iowa State Achievement Test Results}

As a result of No Child Left Behind mandates, states provide annual progress on student achievement. Typically, states report this in three ways: individual school, district-wide, and entire state. In Illinois, students take either the Illinois Standards Achievement Test (ISAT) or the Prairie State Achievement Exam (PSAE) once a year. The ISAT and the PSAE measure individual student achievement in certain subject areas, relative to the Illinois Learning Standards (ISBE, 2011). Therefore, the ISAT and PSAE are standards-based assessments. Students are assessed in grades 3 through 8 with the ISAT, and students in grade 11 take the PSAE. Illinois reports these findings through the online Illinois Interactive Report Card (IIRC) system. Statewide, annual results reported on the Illinois Interactive Report Card began in 2002 with $60 \%$ of the students in Illinois scoring as proficient. In 2006 , state scores increased to $73 \%$. Currently, in 2010, the state average on student achievement is at $76 \%$ proficient (IIRC, 2011).

The Iowa Test of Basic Skills (ITBS) and the Iowa Tests of Educational Development (ITED) are the statewide assessments used to report annual student progress in the state of Iowa, relative to the state's annual objectives (DE, 2011). Therefore, the ITBS and ITED are skills-based assessments. The Iowa Department of Education reports student progress in the same manner as Illinois: individual schools, district-wide, and throughout the state. Iowa students are assessed in third through eighth grades and again in eleventh grade. To report Adequate Yearly Progress (AYP), Iowa uses subtests in the areas of reading comprehension, mathematical concepts, mathemati-cal problem solving, and science analysis (DE, 2011). Iowa reports these findings each year through both the Annual Condition of Education report and the State Report Card for No Child Left 
Behind (DE, 2011). In the Annual Condition of Education report, student results are reported in reading, math, and science. In the State Report Card for No Child Left Behind, student results are reported in only reading and math (DE, 2011). In 2006, $75.3 \%$ of Iowa students scored in the proficient range, with a 1.5 percentage increase in 2010 to $76.8 \%$ (DE, 2010).

Table 6

Individual State Test Results from State Report Cards from 2002 to 2010

\begin{tabular}{lccc}
\hline State & 2002 & 2006 & 2010 \\
\hline Illinois (ISAT.PSAE) & $60 \%$ & $73 \%$ & $76 \%$ \\
Iowa (ITBS/ITED) & $\begin{array}{l}\text { N/A for } \\
\text { all grades }\end{array}$ & $75.3 \%$ & $76.8 \%$ \\
\hline
\end{tabular}

Further analysis of student performance data from 2001 to 2010 shows that the Annual Condition of Education Report itemizes student performance of only students in grades 4,8 , and 11. Student achievement data for fourth, eighth, and eleventh grade students is reported "as average percentages for pairs of consecutive years in the biennium periods from 2001-2003 through 2008-2010 (DE, 2010, p. 197). Table 7 shows that students scoring in the proficient range on these tests increased three percentage points. From the biennium reported years between 2001-2003 to 2008-2010, student proficiency scores increased from $75.8 \%$ to $78.8 \%$ (DE, 2010).

The results of student scores in both states show an increase in student achievement from 2002 to 2010 . Students scoring in the proficient range in Illinois have made a gain of 16 percentage points since 2002. Students scoring in the proficient range in Iowa 
in grades 4, 8, and 11 have made a 3\% gain between 2002 and 2010 (DE, 2003; DE, 2010). The overall student achievement increase results show student performance in third through eighth and eleventh grades going from $75.3 \%$ in $2005-2006$ to $76.8 \%$ in 2009-2010 (DE, 2010). This shows an overall student achievement gain of 1.5\%. These results, along with the NAEP results, bring forth a question regarding how well each state's assessment measures up to national standards of what students should know and be able to do at each grade level.

Table 7

Percent of Fourth, Eighth, and Eleventh Graders Scoring Proficient on ITBS or ITED

\begin{tabular}{lcc}
\hline Biennium Years & $2001-2003$ & $2008-2010$ \\
\hline Percent of Students Proficient & 75.8 & 78.8 \\
\hline
\end{tabular}

NAEP and individual state assessments comparison. A study conducted on how the reading assessments from individual state achievement tests measured up to the reading assessment in the NAEP indicated individual state assessments are not equal to the national assessment (Applegate, Applegate, McGeehan, Pinto, \& Kong, 2009). The methods of this study included examining the fourth grade assessment in selected states using specific criteria. Illinois was one of the states selected. Iowa was not a state selected to be part of this study. The selected states in this NAEP study all had:

- fourth-grade sample tests available online and included enough items to allow for reliable analysis;

- tests that were specifically offered as samples designed to familiarize educators with the format and item types used to measure comprehension; 
- test items were accompanied by the passages upon which they were based; and

- test items were accompanied by designation of the level of thinking the items were intended to assess. (Applegate et al., 2010, p. 373)

In addition to these criteria, each state was compared to the NAEP in three areas:

- Item type-Did the test item use an open-ended or multiple-choice format?;

- Item objective-Was the item intended to assess vocabulary knowledge, familiarity with genre, text organization, characterization, or text detail?; and

- Item purpose and cognitive demand-Did the item require the reader to understand the content of the text (text emphasis), or did the item require the reader to interpret the meaning of the text (higher order)? (Applegate et al., 2010, p. 374)

Applegate et al. (2010) cited researchers and theorists in the area of assessing reading, such as Huey (1908), Thorndike (1917), Anderson (1984), Burke (1996), and Mullis, Kennedy, Martin, and Sainsbury (2006) who all agree that measuring reading achievement must involve "thoughtful literacy—an ability to link the text with one's existing knowledge to arrive at a considered and logical response" (Applegate et al., 2010, p. 372) and forcing readers to use higher order skills in comprehending text. The results of the study found that NAEP assesses the thoughtful literacy discussed as imperative by researchers and theorists to be the premise for reading achievement. The NAEP uses more open-ended items, fewer vocabulary and genre items, and requires more of a thoughtful response on assessed items than individual state assessments (Applegate, 2010). NAEP was found to more closely assess higher order thinking skills in reading comprehension. Table 8 shows how Illinois compares to NAEP in the percentage of questions intended to provoke higher order cognition versus the actual percentage of questions on the test that did require higher order cognition. These results show that individual state assessments are not measuring the same level of reading cognition as is measured on NAEP, the identified national assessment of student achievement. 
Table 8

Percentage of Items Intended vs. Actually Required Higher Order Cognition

\begin{tabular}{lcc}
\hline Test & $\begin{array}{c}\text { Intended to require higher } \\
\text { order cognition }\end{array}$ & $\begin{array}{c}\text { Actually require higher } \\
\text { order cognition }\end{array}$ \\
\hline Illinois (ISAT) & 54.5 & 21.1 \\
NAEP & 93.5 & 67.8 \\
\hline
\end{tabular}

State comparison. An article released in Time magazine in 2007 compared each state's individual achievement test with the National Assessment of Educational Performance. Reported results from every state's achievement scores showed higher proficiency percentages than were reported on NAEP. Though the comparison examines only reading and math scores, Table 9 shows how both Illinois and Iowa faired in this comparison. The percentage of students proficient on the Illinois Standardized Achievement Test (ISAT) was $63 \%$ compared to only $29 \%$ proficient on NAEP. The percentage of students proficient on the Iowa Test of Basic Skills (ITBS) was 78\% compared to $32 \%$ on NAEP (Applegate et al., 2010). These results show a significant difference in the individual state test results compared to the national assessment on student performance. Though No Child Left Behind requires each state to report annual student progress, the specifics of the exam are left up to the individual states (Wallis \& Steptoe, 2007). What these results show is that states seem to be either lowering the proficiency standards and/or making the state assessments easier in order to meet the requirements of Adequate Yearly Progress through NCLB (Wallis \& Steptoe, 2007). This leaves "huge gaps between state results and scores on national standardized tests" (Wallis \& Steptoe, 2007). 
Table 9

State and NAEP Comparison

\begin{tabular}{lcc}
\hline State & $\begin{array}{c}\text { Students Proficient on } \\
\text { State Assessment }\end{array}$ & $\begin{array}{c}\text { Students Proficient on } \\
\text { NAEP }\end{array}$ \\
\hline Illinois & $63 \%$ & $29 \%$ \\
Iowa & $78 \%$ & $32 \%$ \\
\hline
\end{tabular}

\section{School Improvements}

Quality Counts 2011 also provided a state-by-state analysis of schoolimprovement efforts in this time of financial crisis nationwide. Key findings of this analysis included a detailed report on the amount of federal funding provided to the U.S. Department of Education through the American Recovery and Reinvestment Act of 2009. The data showed more funds were given to the U.S. Department of Education than any other federal agency. The EPE Research Center data showed that more than half of all jobs saved or created throughout the nation with these funds were in the education-related field (Education Week, 2010). Though the EPE Research Center data shows most states have limited authority over teacher layoffs and compensation, "states have responded to the pressures of the recession with policy changes" (Education Week, 2010, para. 5).

These policy changes have been directly related to budget areas of teacher-salary schedules, health-insurance benefits, and teacher compensation and dismissal (Education Week, 2011).

\section{Policy Areas to Strengthen}

The NCTQ identified areas in both Illinois and Iowa state policy that were in need of critical attention. The areas focused in this section are only policies that directly affect 
principal accountability in teacher evaluation as it relates $\mathrm{t}$ student achievement. In both Illinois and Iowa, the council made the same recommendations to state polices. Both states were found to be weak in the policy areas of:

- ensuring that teacher evaluations assess effectiveness in the classroom;

- connecting tenure decisions to teacher effectiveness;

- preventing ineffective teachers from remaining in the classroom indefinitely;

- ensuring elementary teachers know the science of reading; and

- ensuring elementary teachers know elementary content in math. (NCTQ, 2011)

\section{Conclusion}

The results from the NCTQ, along with analysis of Illinois and Iowa state policy, show principal accountability measures to be either weak or non-existent in both states. Both states have policies on contractual continued service and standards for evaluation of both teachers and principals. Both states provide some type of training for evaluators, with Iowa being more extensive. Illinois allows each school district to devise both teacher and principal evaluation forms, where Iowa provides a statewide evaluation form for just the beginning level teacher. The areas identified by NCTQ as being weak in policy are the same areas where states can enhance principal accountability measures. Principals should ensure teachers are provided with professional development. The evaluation tool should measure teacher effectiveness. Ineffective teachers should be removed from the classroom. Tenure decisions should tie directly to teacher effectiveness. These are all areas the principal should be held accountable for in state policies through the evaluation of his/her own administrative performance. 
CHAPTER VI

\section{SUMMARY, CONCLUSIONS, AND RECOMMENDATIONS}

\section{Purpose of Study}

The purpose of this study was to review school reform in the U.S and to compare the selected states of Illinois and Iowa to identify the strengths and weaknesses of policies and rules governing principal accountability in teacher evaluation and its relationship to student achievement.

\section{Research Questions}

1. What is the history (from 1965-2010) of federal school reform that holds principals accountable in teacher evaluation as it relates to student achievement?

2. What are the current educational leadership models that hold principals accountable for student achievement?

3. When comparing two selected states (Illinois and Iowa), what are the strengths and weaknesses of policies and rules governing principal accountability in teacher evaluation as it relates to student achievement?

4. What policy recommendations from the two-state analysis and the research can be made to improve the role of the principal as the instructional leader for the benefit of increasing student achievement?

\section{Findings}

Over the past 45 years, improvement in education in the United States has been working on two tracks. On the one-track policy makers and legislatures have been working, developing and instituting various school reforms. On the other track scholars 
and researchers have been working in the area of educational leadership, developing new and innovative theories. These theories have included how the principal, as instructional leader, leads teachers and students to increased student achievement. After a historic survey of both leadership literature and educational reform; and an analysis of how U.S. Supreme Court cases and individual state cases impact decisions and shape practice in the educational system, the two tracks have still not intersected.

Though key U.S. Supreme Court cases and individual state cases have helped shape public education, the findings of this research indicate that federal and state educational reform initiatives have failed to bring substantial policy development for principal accountability in the evaluation of teachers as it relates to student achievement. Until the $21^{\text {st }}$ century federal initiatives of No Child Left Behind (NCLB), Race to the Top (RTTT), and current attempts to reauthorize the Elementary and Secondary Education Act (ESEA), federal education reform has implemented accountability measures primarily for teachers. These accountability measures relate to how teachers positively affect student achievement. Federal reform in the 1960s highlighted closing the gap and providing more services for disadvantaged children. The 1970s brought about increased educational programming for students with disabilities, while the release of A Nation At Risk in the 1980s placed a public target on the American education system. From the 1980 s to 2000 , federal reform efforts required states to develop standards for what students should know and be able to do at each grade level. Reform efforts required curricular alignment of subject areas, and the assessment and reporting of student progress in the subjects of reading, math, and science. Since NCLB and the most recent initiatives of the Obama administration (RTTT and ESEA reauthorization), leadership accountability 
in federal and state reforms has reached higher scrutiny. In the last decade, both Illinois and Iowa have created policies on principal training in the evaluation of teachers. Both states have created principal evaluation standards and principal mentoring programs in an effort to increase principal accountability in positively affecting student achievement. In efforts to receive RTTT funding, Illinois has proposed policy amendments or additions to hold principals accountable in the evaluation of teachers as it relates to student achievement. Iowa has made no policy changes in response to RTTT.

In the analysis of both state policies on principal accountability in the evaluation of teachers, the NCTQ report findings, though argumentatively flawed, highlighted several areas of needed improvement. The areas NCTQ found where both state policies of Illinois and Iowa should be modified specifically to principal accountability in the evaluation of teachers were:

- ensuring that teacher evaluations assess effectiveness in the classroom;

- connecting tenure decisions to teacher effectiveness;

- preventing ineffective teachers from remaining in the classroom indefinitely;

- ensuring elementary teachers know the science of reading; and

- ensuring elementary teachers know elementary content in math. (NCTQ, 2011)

The NCTQ report highlighted specific states in each of the above areas to reference in making policy recommendations for improvement in these areas of accountability. Due to the arguments from the AACTE on the credibility of the NCTQ research, these recommendations are taken with hesitation.

\section{Significance of Findings}

Improving student achievement is our ultimate goal. In order To increase student performance, we must have highly effective educators. The most important factor in working to improve student achievement is the quality of the individual teacher in each 
classroom. The teacher directly affects student achievement and in turn, principals indirectly affect student performance. Principals must work with individual teachers to ensure quality instruction. One way of explaining this is to describe the school leader's role as moving beyond instructional supervision to a leadership for learning (Hackmann et al., 2008). Within this concept of leadership for learning, principals must provide professional development, use data for school improvement, conduct classroom walkthroughs, participate in action research, support and develop Professional Learning Communities, supervise, evaluate, and exhibit curriculum leadership in his/her knowledge of curriculum, instruction, and assessment (Hackmann et al., 2008). Quality of instruction must be measured against high expectations of what students should know and be able to do to compete in our global society. Students must gain more knowledge through quality instruction of teachers; and teachers must gain more knowledge, applying it effectively during instruction because of constructive principal feedback. This feedback should be called a professional growth plan rather than a teacher evaluation. The term 'evaluation' sets a negative tone. A tone in which many individuals find threatening.

The education field has long been operating under two separate thought processes: one of a hiring or firing mentality, where the evaluation process is meant to inform decisions on whether a teacher should be retained or dismiss; and another which is a system of improving instruction through professional development and effective feedback. When the mentality is one of hiring or firing, fear among teachers is heightened and students are not effectively taught. When the model is one of professional growth with the intent to improve instruction, collaboration and collegiality bring a positive working environment. This positive environment promotes maximized student 
performance. Within the concept of leadership for learning, the evaluation /professional growth plan should include a "process of learning and what students learn, not simply the act of teaching" (Hackmann et al., 2008, slide 12). Not only do principals have to model this with teachers, superintendents must model this with principals. This is all accomplished by setting goals with each teacher and continually monitoring individual progress through collaborative conversations on each goal. Student performance results should be one part of the conversation to inform future instruction.

The results of this research show statewide student achievement scores in Iowa to have a slight improvement in student achievement since the 2002 state policy developments in teacher evaluation and administrator training. Student achievement scores in Illinois have shown a higher percentage increase from 2002. Research comparing individual state tests to NAEP in the area of reading show student achievement scores from the state assessment in Illinois (ISAT and PSAE) more closely relate to student achievement results on the national assessment (NAEP) as compared to student achievement scores between the Iowa state assessments (ITBS and ITED) and NAEP (Time, 2007). Even so, policies on principal accountability in the evaluation of teachers as it relates to student achievement should be referenced by the state of Illinois for policy amendments and/or additions. Though Illinois policy states that beginning September 1, 2012, evaluators must attend a more rigorous training and pre-qualification process, the state of Illinois would benefit from components of the teacher evaluation program Iowa has in state policy. Specifically, Illinois should incorporate the statewide teacher evaluation form used by administrators to ensure all teachers are assessed on the same criteria. This form gives a uniform criteria and rating system for all teachers and evaluators throughout 
school districts. In addition, this form would help guide educators across the state to be fully aware and understand what is expected of them in his/her job performance. This form would be the written document in the professional growth plan (rather than being called the teacher evaluation) for each teacher. The form would specify the standards/criteria for teaching. The standards/criteria for teaching would be the same statewide, with a mainstreamed method of documenting individual performance.

A study of Midwest state teacher evaluation tools found Iowa to be the strongest in meeting the 13 characteristics of teacher evaluation identified by the Institute of Education Sciences National Center for Education Evaluation and Regional Assistance (2008). Iowa met 11 of the 13 criteria. Illinois met only 7 . The areas Iowa met that Illinois did not meet were the following:

- external resources used to inform the evaluation;

- different evaluation tools used for content and special populations;

- grievance procedures for teachers clearly communicated in policy. (U.S. Department of Education, 2008)

The characteristics neither Illinois nor Iowa met were:

- different evaluation policies for content areas and special populations in the teacher evaluation process; and

- a policy for the manner in which teacher evaluation results were communicated to teachers. (U.S. Department of Education, 2008)

Developing a streamlined method for measuring teacher professional growth and performance is one way to improve instruction and raise student achievement. Developing policies that are uniform in the professional growth plans of teachers, and stressing that the process is a growth plan rather than a 'hire or fire' evaluation process would cultivate a more collaborative and positive working relationship among teachers and principals. 
Other significant findings in the analysis of Illinois and Iowa came in various national reports (Time, 2007; NAEP, 2010; Quality Counts, 2011; NCTQ, 2011) referencing the policies for principal accountability in states such as Rhode Island, Colorado, and Massachusetts. These states have either exhibited strong student achievement scores and/or instituted drastic policy changes in principal accountability for teacher evaluation. In a nationwide comparison of how closely reading scores on individual state assessments relate to reading scores on NAEP, all three states have a smaller gap in student performance than both Illinois and Iowa. Massachusetts led the way between these states with approximately a 5\% difference in student achievement scores. To make drastic state policy changes in response to RTTT incentives, NCTQ reports show each of these states have made policy updates. Significant changes in Colorado include teacher evaluation being required yearly, with $50 \%$ of the teacher's evaluation based on student growth. Teachers on probationary status must earn three consecutive evaluation ratings of effective to move to nonprobationary status. Veteran or teachers on non-probationary status who receive two consecutive evaluation ratings of ineffective must return to probationary status with a year to improve or be terminated (NCTQ, 2010). In Massachusetts, policy changes in teacher dismissal were identified. "In a school deemed chronically low performing, a nonprobationary teacher can be dismissed for 'good cause' so long as the teacher is given written notice five days prior to the dismissal" (NCTQ, 2010, p. 3) and given the right to appeal. Rhode Island has made some of the most drastic policy changes in teacher evaluation and accountability. All teachers must be evaluated on a 4scale rating system. Teachers are now to be evaluated at least once a year, with $51 \%$ of the yearly evaluation based on student growth and achievement. "Teachers who receive 
two years of ineffective evaluations will be dismissed. Any teacher with five years of ineffective ratings would not be eligible to have his or her certificate renewed by the state" (NCTQ, 2010, p. 3). In addition to teacher evaluation changes, school districts in Rhode Island can no longer make teacher assignment decisions based solely on teacher seniority (NCTQ, 2010).

Keeping with the policies of Rhode Island, statewide student achievement scores have made dramatic increases between the years 2004 to 2010. In 2004, the statewide reading index proficiency was at $81.9 \%$, with 2010 proficiency data at $90.2 \%$. The 2004 statewide math index proficiency scores were at $70 \%$, with scores increasing to $78.5 \%$ in 2010 (RI Department of Education, 2010). These student performance results, paired with the relatively small gap between the Rhode Island state assessment and NAEP show Rhode Island is a leading state in education reform to positively affect student achievement.

What does state policy on principal accountability in the evaluation of teachers and its relationship to student achievement detail in the state of Rhode Island? The Rhode Island state school code details a thorough model evaluation system. This is in response to RTTT's incentives under Great Teachers \& Leaders description. The Rhode Island Department of Education's (RIDE) Strategic Plan "establishes the expectation that by 2015 all Rhode Island8 educators will be evaluated under a comprehensive evaluation system that provides actionable and continuous feedback" (RIDE, 2011). Within this system are standards for teaching and leadership. These include specific standards teachers and principals must be evaluated on and statewide evaluation forms specific to teachers and principals that provide uniformity throughout the evaluation process. The 
name given is the Rhode Island Model Evaluation System (Rhode Island Department of Education, 2011). If school districts in the state do not use the state created evaluation tools, they must create evaluation tools and submit them to the state for approval based on the Rhode Island Educator Evaluation System Standards (Rhode Island Department of Education, 2011). The evaluation system is planned for gradual implementation beginning in the 2011-2012 school year. During the first year of implementation, the state will be continually evaluating the system for effectiveness (Rhode Island Board of Regents, 2011). Safeguards have been put in place to ensure fair and effective assessment. The "evaluation system standards require that safeguards be built into the system, including rigorous training for evaluators and ongoing review of the system" (Rhode Island Board of Regents, 2011, para. 5). The administrator evaluation tool includes specific criteria for principal accountability in the evaluation of teachers as it relates to student achievement. This is a critical step in providing the same type of streamlined professional growth for principals that is stressed for teachers.

Developing a streamlined method for measuring principal professional growth and performance is another way to improve teacher instruction and raise student achievement. Developing policies that are uniform in the professional growth plans of principals would cultivate a collaborative and positive working relationship among teachers and principals. The example Rhode Island principal evaluation tool is included in the appendix.

Along with changing the mindset from 'hire or fire' to a professional growth plan of collaboration among principals and teachers, the practice of tenure needs to be evaluated. Many states are proposing legislation to remove tenure from the public school 
system. Illinois would benefit from this same type of proposed legislation. The current 'power' that the teachers unions in Illinois have with regard to working conditions and tenure status is dangerous to improving student achievement. In many districts, one small change brought on by the principal or superintendent is cause for renegotiating the contract of teachers. As long as individual school districts have bargaining units that are allowed to negotiate policies and practices proven to improve student achievement, the educational system will remain in stagnant and scrutinized under the public's eye. Currently, teachers' unions and individual school district bargaining units in Illinois are allowed to negotiate anything they choose. These unions and individual school district bargaining units must be given a list of specific conditions they are allowed to negotiate, noting all other conditions are non-negotiable. As long as teachers' unions in Illinois are allowed to bargain at whim, change in working conditions will be difficult and student achievement will continue to suffer.

\section{Recommendations}

"A coordinated strategy begins with the development of a coherent framework that everyone understands" (Baker \& Vogel, 2004, p. 8). The following list of recommendations for the state of Illinois will enhance principal accountability in professional growth plans in the evaluation of teacher performance to positively affect student achievement. These recommendations are a combination of what has been effective policy reform in other states or is being implemented in other state policy and is recommended in the literature on principals as instructional leaders.

1. The term 'teacher evaluation' is to be replaced with 'teacher professional growth plan'. 
2. A significant portion of a principal's evaluation is to be based on the development and quality completion of professional growth plans in the evaluation of teacher performance.

3. A significant portion of a principal's evaluation is to be based on student achievement scores.

4. A committee consisting of representatives from various educational groups: teachers, administrators, state education associations, state board of education members, and policymakers will create a statewide evaluation/professional growth plan form for both teachers and principals/administrators. This form is to be used for professional growth plans in the evaluation of performance based on specific and agreed upon performance criteria in both teaching and leadership.

5. A committee consisting of representatives from various educational groups: teachers, administrators, state education associations, state board of education members, and policymakers will create a statewide electronic form (to be kept in a central database) for superintendents to complete, in conjunction with the end of the school year reports. This form verifies principals have complied with and effectively completed professional growth plans in the evaluation of teacher performance that school year.

6. If the concept of tenure remains, aspiring administrators are required to have successfully reached tenure in at least one school district (or must have taught for at least five years, with successful evaluations) before being qualified to move into an administrative position.

7. The process of tenure is to be dissolved in the state of Illinois. Teachers would be evaluated through professional growth plans, where specific goals are developed, 
monitored, and assessed each year through collaborative conversations between the principal and teacher; and classroom observation(s) by the principal. Continued employment is to be based on these professional growth plans rather than the current state policy of tenure/nonprobationary status protection.

Recommendation one provides a more positive tone to performance reviews of educators. Rather than saying it is a 'teacher evaluation' of performance, it is recommended to call the system of performance review a 'professional growth plan'. This sets a more positive tone and is intended to bring about collaborative efforts between teachers and principals in the evaluation of individual performance to increase student achievement. Recommendations two and three are in direct correlation to the policy development of many states requiring a significant percentage of teacher evaluations/professional growth plans to include measures of student growth and performance. If a significant portion of a teacher's evaluation/professional growth plan is based on student growth and performance on multiple measures, principals must also be held accountable for the direct and indirect roles they play in student achievement. Requiring a significant portion of a principals evaluation to be based on both student achievement scores and effectively evaluating teachers, which includes providing teachers with appropriate professional development, collecting data to inform instructional decisions, and having knowledge of curriculum and instruction would be equivalent to the 2012 state policy on teacher evaluations.

Recommendation four would help create a comprehensive evaluation framework that school districts would use state-wide to evaluate principals/administrators, on specific standards and criteria related to the expectations and responsibilities principals 
have for the evaluation of teachers/development and monitoring of professional growth plans and increasing student achievement. Recommendation five would create a streamlined system to hold superintendents accountable to ensure principals are effectively evaluating teachers/developing and monitoring professional growth plans. Though the report would be sent to the state board of education, the main purpose would be for superintendents to ensure principals are effectively evaluating teachers/developing and monitoring professional growth plans. Superintendents would not be required to look at every evaluation, but it would bring heightened awareness to the superintendent to inform professional development needs of principals in the district. Recommendations four and five would clearly state to the principal what the expectations are for his/her performance as an instructional leader.

The sixth recommendation of requiring a principal to show evidence of at least five years of successful teaching tags on to the proposed requirement in higher education programming. Within the proposal, a candidate must have completed 4 years of teaching before entering a program of educational administration. This recommendation increases that proposal by one year. Years of experience in the classroom directly relate to instructional knowledge and skill level of teachers (Blasé \& Kirby, 2009). Having the understanding of curriculum and instruction, using data to inform instructional decisions in the classroom, and an awareness of measuring student achievement as a teacher circle back to the research on the effectiveness of a principal as instructional leader (Bass, 1990; Blasé \& Kirby, 2009; Danielson, 2008; Fullan, 2002; Hoerr, 2005; Marzano, 2003; Marzano et al., 2005; Strong et al., 2008). To be an effective leader of a school, one should have shown evidence of effective classroom performance. 
The final recommendation is to dissolve tenure in the state of Illinois. The principles of teacher tenure must be re-evaluated in the state. No longer can it be so difficult to remove an ineffective teacher from the classroom. Tenure has made it nearly impossible and extremely expensive for ineffective teachers to be dismissed school districts across the state. Evaluating teacher performance through professional growth plans should replace the state policy provisions of tenure/nonprobationary status. Within these professional growth plans, goals are to be developed, monitored, and assessed by both the principal and teacher throughout the year to identify improvement areas for the benefit of student achievement.

The ultimate goal is to develop a better system in education to monitor and guide the performance of all educators. Policymakers and legislators must look at educational reform in terms of bettering schools and providing maximized opportunity for student performance. Policymakers and legislators must stop creating reform efforts that give excuses for teachers and individual schools to continue to perform poorly. All schools, private and public, must work together rather than compete with one another for the enhancement of our nations future, our children.

\section{Future Research}

Research inherently identifies other areas of future study. Through this histography of educational reform and document analysis of state policies, several other areas of future study can be identified. The following are suggested topics for future study:

1. Educators and policymakers would benefit from future research conducted on analyzing how to better correlate the Illinois assessments of student achievement (ISAT 
and PSEA) to the National Assessment on Educational Progress (NAEP). A study conducted on the variables between assessments would allow individual state assessments to more accurately measure student performance.

2. In response to RTTT, states have begun implementing various policies on educator evaluation. Educators and policymakers would benefit from a study conducted on the effectiveness and feasibility of these new policies.

3. A study conducted on how much emphasis and daily instruction various states and/or school districts place on 'teaching to the test' in the curriculum could help identify variables between student achievement scores on the individual state test versus student achievement scores on NAEP.

4. Though this study analyzed legal policy documents, a qualitative study conducted by interviewing evaluators across the state of Illinois would help evaluation committees assess and inform the continuation of current policies or practices, as well as the formation of future policies and practices.

5. Finally, this histography of educational reform and policy analysis has shown a strong focus on the development of standards for what students should know and be able to do in all grade levels and subject areas. Though this study does not discuss the newly adopted Common Core standards across the nation, future research would be beneficial in how these new standards reshape curriculum and individual state assessments.

\section{Conclusion}

Evaluating the performance of teachers by developing professional growth plans to promote and enhance continual learning for all educators is very important to positively affecting student achievement. The primary individual responsible for directly 
increasing student achievement is the teacher. The primary individual responsible for improving teacher performance and indirectly affecting student achievement is the principal. As the instructional leader, the principal is responsible for supervising and evaluating performance, guiding appropriate professional development, and providing effective feedback to inform instruction that ultimately increases student achievement. The responsibility of working collaboratively with teachers on goals in professional growth plans to evaluate performance must never be delegated to other individuals, no matter what the law states. The principal must be the instructional leader who promotes leadership in learning throughout the school. The principal must have a strong knowledge of curriculum, instruction, and assessment to drive school-wide increases in student achievement. Just as teachers are expected to provide effective instruction and assess student knowledge, so too should the principal. The principal may not be providing direct instruction to the students, yet he/she is providing direct instruction to individual teachers through the supervision and evaluation process. Whatever phrase we choose to use, the principal must provide effective teacher evaluations to enhance student learning. Recent reform efforts have brought accountability measures to teachers in order to positively affect student achievement. Accountability must start with the school leader. Principal accountability measures must now be developed in state policies so teachers are supported as they work directly to increase student achievement. Principals and teachers working collaboratively through observations, conversations, and goal setting will positively enhance student learning and prepare our students to compete in the global society. 


\section{REFERENCES}

Alexander, K., \& Alexander, M. D. (2005). American public school law (6 $6^{\text {th }}$ ed.). Belmont, CA: Thomson West.

Alexander, L., \& James, T. (1987). The nation's report card: Improving the assessment of student achievement. Report of the study group. Cambridge: MAL National Academy of Education.

American Association of Colleges of Teacher Education (AACTE). (2011). Retrieved from http://www.aacte.org/index.php?/traditional-media/resources/aactemembers-respond-to-nctq-qresearch-efforts.html

Anderson, R. C. (1984). Role of the reader's schema in comprehension, learning and memory. In R. C. Anderson, J. Osborn, \& R. J. Tierney (Eds.), Learning to read in American schools: Basal readers and content texts (pp. 243-257). Hillsdale, NJ: Erlbaum.

Applegate, J. A., Applegate, M. D., McGeehan, C. M., Pinto, C. M., \& Kong, A. (2009). The assessment of thoughtful literacy in NAEP: Why the states aren't measuring up. The Reading Teacher, 62(5), 372-381.

Archiving Early America. (2010). Retrieved from http://www.earlyamerica.com/review/winter96/jefferson.html

Armstrong, T. (2006). The best schools: How human development research should inform educational practice. Alexandria, VA: ASCD.

Baker, P. J., Ashby, D., \& Rau, W. (1997) Local response to state mandated reform: A study of the Illinois public school accreditation process. Normal, IL: Illinois State University.

Baker, P. J., \& Vogel, L. (2004). Leadership and school reform: Moving from contradictions to coherence. Paper presented at international conference Making educational reform happen: learning from the Asian experience and comparative perspectives. Bangkok, Thailand.

Barth, R. (2002, May). The culture builder. Educational Leadership, 59(8), 6-11. 
Bass, B. M. (1985). Leadership and performance beyond expectations. New York: Free Press.

Bass, B. M. (1990). Bass and Stogdill's handbook of leadership. New York: Free Press.

Bass, B. M., \& Avolio, B. J. (1994). Improving organizational effectiveness through transformational leadership. Thousand Oaks, CA: Sage.

Bell, T. H. (1986). A nation still at risk. The states of the schools: A special report. Principal, 66(1), 5-6.

Bell, T. H., (1998). The thirteenth man: A Reagan cabinet memoir. New York: Free Press.

Biers, S. (n.d.). 4 LawSchool. Retrieved from http://www.4lawschool.com/conlaw/haldeman/htm

Blasé, J., \& Kirby, P. C. (2009). Bringing out the best in teachers: What effective principals do $\left(3^{\text {rd }}\right.$ ed.). Thousand Oaks, CA: Corwin Press: A Sage Publications Company.

Broadway, J. (2010). State school news. Retrieved from www.stateschoolnews.com

Brown v. Board of Education, 347 U.S. 483 (1954) U.S. Lexis 2094.

Burns, J. M. (1978). Leadership. New York: Harper \& Row.

Bush, G. H. (1990). Address before a joint session of the congress on the state of the union, January 31, 1990. Weekly Compilation of Presidential Documents (Washington, DC: National Archives and Record Administration, February 5), pp. 147-148.

Cawelti, G. (1999). Portraits of six benchmark schools: Diverse approaches to improving student achievement. Arlington, VA: Educational Research Service.

Common Core State Standards Initiative. (2011). Retrieved from http://www.corestandards.org/in-the-states

Congressional research service report for Congress. (2002). The Library of Congress.

Cooper, B. S., Ehrensal, P. A., \& Bromme, M. (2005, January/March). School-level politics and professional development: Traps in evaluating the quality of practicing teachers. Educational Policy, 19(1), 112-125.

Cotton, K. (2003). Principals and student achievement: what the research says. Alexandria, VA: ASCD. 
Cox v. York County School District, No. 083, 560 N.W. 2d 138 (Nebraska 1997).

Danielson, C. (1996). Enhancing professional practice A framework for teaching. Alexandria, VA: ASCD.

Danielson, C. (2001, February). New trends in teacher evaluation. Educational Leadership, 58(5), 12-16.

Danielson, C. (2008). The handbook for enhancing professional practice: Using the framework for teaching in your school. Alexandria, VA: ASCD.

Darling-Hammond, L. (2003, May). Keeping good teachers: Why it matters, what leaders can do. Educational Leadership, 60(8), 6-13.

Davis v. Macon County Board of Education No. COA05-1337 (N.C. 2006).

Developmentally Disabled Assistance \& Bill of Rights Act of 1975 (42 USCS 6010).

Edmonds, R. (1979, October). Effective schools for the urban poor. Educational Leadership, 37(1), 15-23.

EdSource. (1996-2010). Clarifying complex education issues: Categorical aid. Retrieved from http://www.edsource.org/pub_abs_categorical.htm

Education Week. (2011). Quality counts 2011 press release. Retrieved from http://www.edweek.org/ew/toc/2011/01/13/index.html

Ellett, C. D., \& Teddlie, C. (2003). Teacher evaluation, teacher effectiveness and school Effectiveness: Perspectives from the USA. Journal of Personnel Evaluation in Education, 17(1), 101-128.

Elmore, R. F. (2000). Building a new structure for school leadership. New York: Albert Shanker Institute.

Essex, N. L. (2009). The 200 most frequently asked legal questions for educators. Thousand Oaks, CA: Corwin Press: A Sage Publication Company.

Friedman, I. C. (2004). Library in a book: Education reform. New York: Facts on File, Inc.

Fuchs, D., \& Fuchs, L. S. (2006). Introduction to response-to-intervention: What, why, and how valid is it?" Reading Research Quarterly, 41(1), 93-99.

Fullan, M. (1991). The new meaning of educational change. New York: Teachers College Press. 
Fullan, M. (2001). The new meaning of educational change ( $3^{\text {rd }}$ ed.). New York: Teachers College, Columbia University.

Fullan, M. (2002, May). The change leader. Educational leadership, 59(8), pp. 16-20.

Greenleaf, R. (1977). Servant leadership: a journey into the nature of legitimate power and greatness. New York: Paulist Press.

Greenleaf, R. K. (2002). Servant leadership. New York: Paulist Press.

Goldrick, L. (2002). Improving teacher evaluation to improve teaching quality. Washington, DC: National Governors Association. Retrieved February 15, 2009, from http://www.nga.org/Files/pdf/1202IMPROVINGTEACHEVAL.pdf.

Goodman, Y. M., Watson, D. J., \& Burke, C. L. (1996). Reading strategies: Focus on comprehension ( $2^{\text {nd }}$ ed.). Katonah, NY: Richard C. Owens.

Darling-Hammond, L., \& Sykes, G. (2003). Wanted: A National Teacher Supply Policy for Education: The right way to meet the 'highly qualified teacher' challenge. Educational Policy Analysis Archives, 11(33). http://epaa.asu.edu/epaa/v1 ln33/

Hackmann, D. H., Kose, B., Zola, D., \& Colwell, B. (2008). An introduction to the evaluation of certified staff: "Learning-focused supervision and evaluation." Presenter Manual. [PowerPoint slides].

Harlacher, J. E., Walker, N. J., \& Sanford, A. K. (2010). Research-based factors for intensifying instruction. Teaching Exceptional Children. July 1. HighBeam Research. http://www.highbeam.com/doc/1P3-2071653641.html

Herald-News. (January 7, 2000). Education goals 2000: Mostly unmet, still needed. Copley News Service.

Hazi, H. M., \& Rucinski, D. A. (2009). Teacher evaluation as a policy target for improved student learning: A fifty-state review of statute and regulatory action since NCLB. Education Policy Analysis Archives, 17(5).

Holland, J. G. (1855). History of western Massachusetts v. 1 Samuel Bowles and Company. Springfield, MA.

Hoerr, T. R. (2005). The art of school leadership. Alexandria, VA: ASCD.

Hoyle, J. R. (2006). Leadership, national standards. encyclopedia of educational leadership and administration. Thousand Oaks, CA: Corwin Press, A Sage Publication Company.

Huey, E. B. (1908). The psychology and pedagogy of reading. New York: Macmillan. 
Hunt, J. W. (April, 2008). A nation at risk and no child left behind: Déjà vu for administrators? Phi Delta Kappan, 580-585.

Illinois Educators Association. (2010). New evaluation law in Illinois.

Illinois General Assembly. (2010). P.A. 096-0861 Retrieved from http://www.ilga.gov/legislation/publicacts/96/096-0861.htm

Illinois Interactive Report Card. (2010). Retrieved from http://iirc.niu.edu/District.aspx?source=Test_Results\&source2=ISAT\&districtID $=15016299025 \&$ level $=\mathrm{D}$

Illinois State Board of Education. (2011). Illinois Learning Standards. Retrieved from $\mathrm{http}: / / \mathrm{www}$. isbe.net/assessment/isat.htm

Illinois State University. (2007). A concise history. Retrieved from president.illinoisstate.edu/brief_history

Illinois Association of School Boards. (2008). 2008. Illinois School Code. Charlottesville, VA. Matthew Bender \& Company, Inc.

Institute for Educational Leadership. (1991). Voices from the field: 30 expert opinions on America 2000, the Bush administration strategy to 'reinvent' America's schools. Washington, DC: William T. Grant Foundation Commission on Work, Family, and Citizenship.

Iowa Department of Education. (2010). Retrieved from http://www.iowa.gov/

Iowa Department of Education. (2010). Annual condition of education report.

John Dewey project on progressive education. (2002). University of Vermont. Retrieved from http://www.uvm.edu/ dewey/articles/proged.html

Kaplan, L. S., Owings, W. A., \& Nunnery, J. (2005). Principal quality: A Virginia study connecting interstate school leaders licensure consortium standards with student achievement. NASSP Bulletin, 89(643), 28-44.

Kaye, R. (2010, February 24). All teachers fired at Rhode Island school. CNN U.S. Retrieved from http://articles.cnn.com/2010-0224/us/rhode.island.teachers _1_teachers-union-troubled-school-reading-specialists?_s=PM:US

Klotz, M. B. (2007). Response to intervention (RTI): A primer for parents. NASP.

Knudsen, L., \& Morrissette, P. (1998). Goals 2000: A critique and analysis. International Electronic Journal for Leadership in Learning, 2 (4). [Online], Available: http:/www.ucalgary.ca $\sim$ iejll 
Krigman, E. (2010, May 23). Colorado teacher evaluation statute, backed by one teachers' union, may indicate national shift. Los Angeles Times.

Koretz, D. M., Boston Coll., C. Y., Rand Corp., S. G., \& And, O. (1992). National Educational Standards and Testing: A Response to the Recommendations of the National Council on Education Standards and Testing. Congressional Testimony. Retrieved from EBSCOhost. Kuptz v. Youngstown City School District OH 1676, 175 3d 738 (2008).

Laden, M. (2010). No child left behind and teacher evaluations. Retrieved from http://www.suite101.com

Lasswell, T. A., Pace, N. J., \& Reed, G. A. (2008). Weighing in: Rural Iowa principals' perceptions of state-mandated teaching evaluation standards. The Rural Educator, 29(3), 40-44.

Leithwood, K., \& Jantzi, D. (October 2008). Linking leadership to student learning: the contributions of leader efficacy. Educational Administration Quarterly, 44(4) $496-528$.

Madden, J. V., Lawson, D. R., \& Sweet, D. (1976). School effectiveness study. Sacramento, CA: State of California Department of Education.

Marks, H. M., \& Printy, S. M. (2003, August) Principal leadership and school performance: An integration of transformational and instructional leadership. Educational Administrative Quarterly, 39(3), 370-397.

Marshall, P. L., Baucom, D. V., \& Webb, A. L. (1998, May-June). Do you have tenure and do you really want it? The Clearing House, 71(5), 302-204.

Marzano, R. J. (2003). What works in schools: Translating research into action. Alexandria, VA: ASCD.

Marzano, R. J., Waters, T., \& McNulty, B. A. (2005). School leadership that works: From research to results. Alexandria, VA: ASCD.

Maxwell, L. A. (2008, September). D.C.'s chancellor makes her case. Education Week, $28(2), 22-25$.

McGreal, T. L. (1988). Evaluation for enhancing instruction: Linking teacher evaluation and staff development. Alexandria, VA: ASCD.

Mendro, R. L. (1998). Student achievement and school and teacher accountability. Journal of Personnel Evaluation in Education, 12, 257-267.

Milliken v. Bradely, 418 U.S. (1974) U.S. Lexis 94. 
Mulcahy, D. G. (1994, November). Goals 2000 and the role of the national education standards and improvement council. Paper presented at the Annual Conference of the American Educational Studies Association. Chapel Hill, NC.

Mullis, I. V. S., Kennedy, A. M., Martin, M. O., \& Sainsbury, M. (2006). PIRLS 2006 assessment framework and specifications ( $2^{\text {nd }}$ ed.). Chestnut Hill, MA: Boston College, International Study Center.

National Assessment of Educational Progress. (2010). Retrieved from http://nces.ed.gov/

National Commission on Excellence. (1983). A nation at risk. Washington, DC: U.S. Department of Education.

NAESP, (2008). Leading Learning Communities: Standards for what principals should know and be able to do ( $2^{\text {nd }}$ ed.). NAESP. Alexandria, VA.

Nason, N. C. (1871). Board of education of the state of Illinois. Illinois Teacher Office. Springfield, IL: ISBE.

National Center for Education Evaluation and Regional Assistance (NCEERA). (July, 2008). REL technical brief: state policies on teacher evaluation practices in the Midwest region. No. 004. U.S. Department of Education

National Commission on Excellence in Education. (1983). A nation at risk. (Archives). Retrieved from http://www2ed.gov/pubs/NatAtRisk/risk.hmtl

National Council on Teacher Quality. (2010). Retrieved from www.nctq.org

National Governors' Association. (1986). Time for Results, p. 3.

Nitta, K. A. (2008). The politics of structural education reform. New York: Taylor $\&$ Francis.

No Child Left Behind Act of 2001, 20 U.S.C. $\S 6301$ (2002).

North Carolina Department of Administration. (n.d.). Division of non-public education. Retrieved from http://www.ncdnpe.org/vouch.aspx

Painter, S. R. (2000). Principals' efficacy beliefs about teacher evaluation. Journal of Educational Administration, 38(4), 368-378.

Pennhurst State School and Hospital et al. v. Halderman et al. 451 U.S. 1, 17 (1981) U.S. Lexis 12 .

Pennsylvania Association for Retarded Children (PARC) v. Commonwealth (1971) 334 F. Supp 1257 (E.D. PA 1972). 
Peterson, P. E. (Ed.). (2003). Our schools \& our future: Are we still at risk? Stanford, CA: Hoover Institution Press.

Plessy v. Ferguson, 163 U.S. 537 (1896) U.S. Lexis 3390.

Portin, B., Schneider, P., DeArmond, M., \& Gundlach, L. (2003, September). Making sense of leading schools: A study of the school principalship. Seattle, WA: Center on Reinventing Public Education.

Raitzik v. Board of Education of the City of Chicago No. 1-03-3574 (2005).

Ravitch, D. (2010). The death and life of the great American school system: How testing and choice are undermining education. New York: Basic Books.

Results Iowa: Accountability for Iowa. (2008). Retrieved from: http://www.resultsiowa.org/educ.html@measure_1

Rhode Island Board of Regents Elementary and secondary Education. (2011). Retrieved from http://www.ride.ri.gov/

Rhode Island government. (2010, August). Press Release: Rhode Island wins Race to the Top funding in second phase. Retrieved from http://www.ri.gov/press/view/12055

Sanchez, R. (1996, March 28). Governors vow to set higher academic goals without federal involvement. The Washington Post, p. A13.

Sanchez, Rene. (August 15, 1996). Goals 2000 program goes after a rebound. Retrieved from HighBeam Research. http://www.highbeam.com/doc/1P2-792817.html

Sarason, S. B. (1990). The predictable failure of educational reform. Can we change course before it's too late? The Jossey-Bass Education Series and the JosseyBass Social and Behavioral Science Series. Retrieved from EBSCOhost.

Snyder v. Mendon-Union Local School District Board of Education, OH 661 N.E. 2d, 717 (1996).

Spillane, J. P., Halverson, R., \& Diamond, J. B. (2001). Investing school leadership practice: A distributed perspective. Educational Researcher, 30(3), 23-28.

Stallings, D. T. (2003). Duke University; A brief history of the United States department of education: 1979-2002. Durham, NC: Center for Child and Family Policy, Duke University.

State of Massachusetts. (1993). Massachusetts legislature general laws. Retrieved from http://archives/lib.state.ma.us/actsResolves/1993/1993aefs0071.pdf 
Stevenson, D. L. \& Schiller, K. S. (1999). State education policies and changing school practices: Evidence from the national longitudinal study of school, 19801993. American Journal of Education, 107. The University of Chicago.

Stronge, J. H. (2006). Evaluating teaching ( $2^{\text {nd }}$ ed.): A guide to current thinking and best practice. Thousand Oaks, CA: Corwin Press, A Sage Publication. Company.

Stronge, J. H., Richard, H. B., \& Catano, N. (2008). Qualities of effective principals. Alexandria, VA: ASCD.

Stronge, J. H., \& Tucker, P. D. (2003). Handbook on teacher evaluation: Assessing and improving performance. Larchmont, NY: Eye on Education.

Stumbo, C., \& McWalters, P. (2011). Measuring effectiveness: What will it take? Educational Leadership, 68(4), 10-15.

Sullivan, K. A., \& Zirkel, P. A. (1998). The law of teacher evaluation: Case law update. Journal of Personnel Evaluation in Education, 11.367-380.

Superfine, B. M. (2008). Using the courts to influence the implementation of no child left behind. Cardozo Law Review, 28(2), 779-846.

Taking Root: Massachusetts' lesson for sustaining the college-and-career-ready agenda. (2009). Achieve and American Diploma Project Network.

The Higher Education Academy. (2010, June 4). Legal research: defining the concept. Retrieved November 22, 2010 from http://www.ukcle.ac.uk/resources/teachingand-learning-strategies/concept/

The Iowa Legislature. (2010). Retrieved from http://search/legis/state/ia/us/

The Library of Congress: Thomas. (February 17, 1998). Goals 2000: Education America Act Implementation status and issues. CRS report for Congress. Retrieved from http://thomas.loc.gov/cgi-bin/bdquery/z?d103:SN01150:@@@\&summ2=m\&

The Library of Congress: Thomas. (2010). Retrieved from http://thomas.loc.gov/cgi-bin/query/2?c111:H.R.1.enr:

The Library of Congress: Thomas. (2010). Retrieved from http://thomas.loc/gov.cgi-bin/query/F?c111:1:.temp/ c1114SsEib:e173300:

The New Teacher Project. (October 8, 2010). Teacher evaluation 2.0. Retrieved from http://www.tntp.org/files/Teacher-Evaluation-Oct10F.pdf. 
The New Teacher Project. (2011). Retrieved from www.ntp.org

The New York Times. (October 1, 1989). Ideas \& trends: 'A Jeffersonian compact'; The statement by the president and governors.

State of New York, Office of Education Performance Review. (1974). School factors influencing reading achievement: A case study of two inner city schools.

Thorndike, E. L. (1917). Reading as reasoning: A study of mistakes in paragraph reading. Journal of Educational Psychology, 8(6), 323-332. doi: $10.1037 / \mathrm{h} 0075325$

Turque, B. (n.d.) Michelle Rhee resigns as D.C. schools chief. The Washington Post Retrieved from Newspaper Source database.

United National Educational. (1987). Scientific and cultural organization. Charlottesville, VA. Retrieved from http://www.monticello.org/site/researchand-collections/bill-more-general-diffusion-knowledge

U.S. Const. amend. I.

U.S. Const. amend. IV.

U.S. Const. amend. V.

U.S. Const. amend. VIII.

U.S. Const. amend. X.

U.S. Const. amend. XIV.

U.S. Department of Education. (2001). Archived information. Retrieved from www2.ed.gov/G2K/myths.html.

U.S. Department of Education. (2004). Overview executive summary. Retrieved from http://www2.ed.gov/nclb/overview/intro/execsumm/html

U.S. Department of Education. (2007). Office of special education programs. Retrieved from http://idea.ed.gov/explore/view

U.S. Department of Education. (2008). Grants: Apply for a grant. Retrieved from http://www2.ed.gov/fund/grants-apply.html

U.S. Department of Education (2008). Senior staff Margaret Spellings: U.S. secretary of education. Retrieved from http://www2.ed.gov/news/staff/bios/spellings.html 
U.S. Department of Education. (2009). General education department: American recovery and reinvestment act of 2009. Retrieved from http://www2.ed.gov/policy/gen/leg/recovery/index.html

U.S. Department of Education. (2009). General state fiscal stabilization fund. Retrieved from http://www2.ed.gov/policy/gen/leg/recovery/factsheet/stabilization-fund.html

U.S. Department of Education. (2009). Office of post secondary education. Retrieved from http://www2.ed.gov/about/offices/list/ope/trio/triohistory.html

U.S. Department of Education. (2010). Elementary \& secondary education. Retrieved from http://www2/ed/gov/policy/elsec/leg/blueprint/index.html

U.S Department of Education. (2010). Elementary \& secondary education: Built for teachers. Retrieved from http://www2.ed.gov/policy/e/sec/leg/bludprint/ teachers/publication_pf3.hml\#respect

U.S. Department of Education. (2010). NAEP. Retrieved from http://www.ed.gov/category/keyword/naep

U.S. Department of Education. (2010). Nine states \& the District of Columbia win Second round Race to the Top grants. Retrieved from http://www.ed.gov/news/ press-releases/nine-states-and-district-columbia-win-second-round-race-to-thetop grants

U.S. Department of Education. (2010, March). Press Release: Delaware and Tennessee win first Race to the Top grants. Retrieved from http://www2.ed.gov/news/pressreleases/2010/03/03292010.html

U.S. Department of Education. (2010). Race to the Top applications submitted for phase 1. Retrieved from http://www2.ed.gov/blog/2010/01/race-to-the-top-41applications-submitted-for-phase-1/

U.S. Department of Education. (2010). Race to the Top assessment program. Retrieved from http://www2.ed.gov/programs/racetothetop-assessment/index.html

U.S. Department of Education. (2010). Race to the Top winners. Retrieved from $\mathrm{http} / / / \mathrm{www}$. ed.gov/blog/2010/08/race-to-the-top-winners/

U.S. Department of Education. (2010). Race to the Top: Technical review form-Tier 2. Retrieved from http://www2.ed.gov/programs/racetotthetop/phase2applications/comments/District-of-Columbia.pdf 
U.S. Department of Education. (2010). Race to the Top: Technical review form-Tier 2. Retrieved from http://www2.ed.gov/programs/racetotthetop/phase2applications/comments/Florida.pdf

U.S. Department of Education. (2010). Race to the Top: Technical review form-Tier 2. Retrieved from http://www2.ed.gov/programs/racetotthetop/phase2applications/comments/massachusetts.pdf

U.S. Department of Education. (2010). Senior staff Arne Duncan. Retrieved from http://www2.ed.gov/news/staff/bios/duncan.html

Vinovskis, M. A. (1999). The road to Charlottesville: The 1989 education summit. Department of History, Institute for Social Research, and School of Public Policy. University of Michigan.

Vinovskis, M. A. (2009). From a nation at risk to no child left behind: National education goals and the creation of federal education policy. New York: Teachers College Press.

Wallis, C., \& Steptoe, S. (June 4, 2007). Report card on no child left behind. Time Magazine.

Waters, T., Marzano, R. J., \& McNulty, B. A. (2003). Balanced Leadership: What 30 years of research tells us about the effect of leadership on student achievement. Aurora, CO: Mid-Continent Research for Education and Learning.

Weber, G. (1971). Inner-city children can be taught to read four successful schools. Washington, DC: Council for Basic Education.

Weintraub, B. (September 29, 1989). Bush and governors set education goals. New York Times. Retrieved from http://query.nytimes.com/gst/fullpage.html?res=950DE3D7173DF93AA1575AC 0A96F948260

West, M. R. (2005). No child left behind: How to give it a passing grade. Policy Brief No. 149. Retrieved from $w w w . b r o o k i n g s . e d u / c o m m / p o l i c y b r i e f s / p b 149 . p d f$

Westbrook, R. B. (1992). Schools for industrial democrats: The social origins of John Dewey's philosophy of education. American Journal of Education, 100(4), 401-19. Retrieved from EBSCOhost.

Young, M. W. (1993). Countdown. The Goals 2000: Educate America Act. National Forum: Phi Kappa Phi Journal, 73(4), 3-4. Retrieved from EBSCOhost.

Ysseldyke, J., \& Algozzine, B. (2006). A practical approach to special education for every teacher: Effective assessment. Thousand Oaks, CA: Corwin Press. 
APPENDIX

RHODE ISLAND PRINCIPAL EVALUATION 
1B. Builds and maintains an inclusive process for creating and sustaining the school mission, vision, and goals, which builds common beliefs and dispositions and genuine commitment among staff, parents, students, and other stakeholders

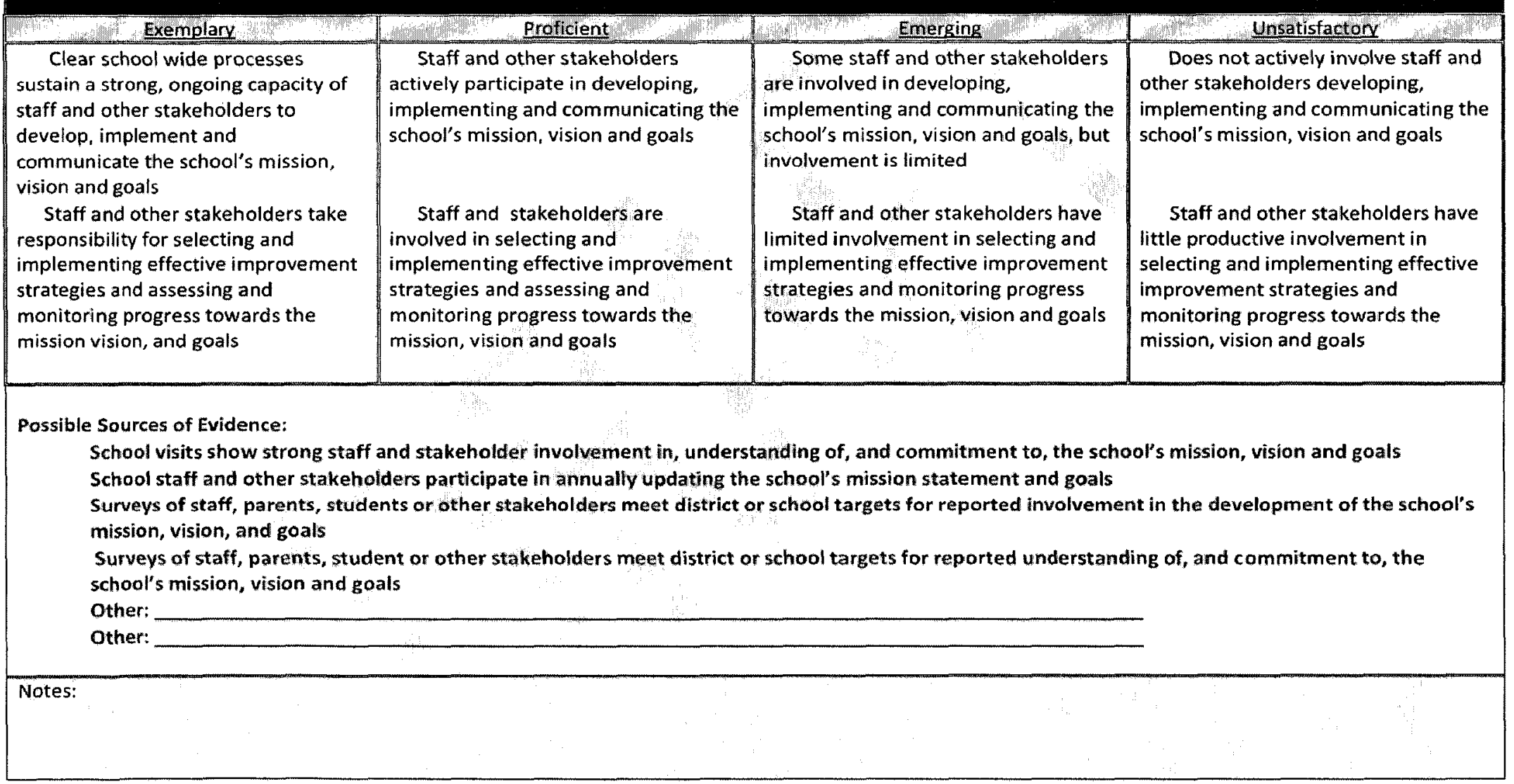




\begin{tabular}{|c|c|c|c|}
\hline Exemplary & 40. Proficient & Emerging & 2198 Unsatisfactory \\
\hline $\begin{array}{l}\text { Comprehensive, sustainable } \\
\text { systems and processes drive planning } \\
\text { and prioritizing, managing change, } \\
\text { using research and best practices, } \\
\text { monitoring progress, and allocating } \\
\text { resources, resulting in a school wide } \\
\text { continuous improvement cycle that } \\
\text { engages all stakeholders and } \\
\text { overcomes barriers to achieving the } \\
\text { school's mission, vision and goals }\end{array}$ & $\begin{array}{l}\text { Clear and effective systems and } \\
\text { processes drive planning and } \\
\text { prioritizing, managing change, using } \\
\text { research and best practices, } \\
\text { monitoring progress, and allocating } \\
\text { resources to address barriers to } \\
\text { achieving the school's mission, vision, } \\
\text { and goals }\end{array}$ & $\begin{array}{l}\text { Some systems and processes drive } \\
\text { planning and prioritizing, managing } \\
\text { change, using research and best } \\
\text { practices, monitoring progress, and } \\
\text { allocating resources, but they are not } \\
\text { clear, or not fully effective in } \\
\text { addressing barriers to achieving the } \\
\text { school's mission, vision and goals }\end{array}$ & $\begin{array}{l}\text { Attempts to address school } \\
\text { challenges without clear systems or } \\
\text { processes for planning and } \\
\text { prioritizing, managing change, using } \\
\text { research and best practices, } \\
\text { monitoring progress, and allocating } \\
\text { resources }\end{array}$ \\
\hline \multirow{2}{*}{\multicolumn{4}{|c|}{$\begin{array}{l}\text { Possible Sources of Evidence: } \\
\text { School visits reveal strong systems and processes for regularly reviewing data at the school, grade, team, subgroup, and subject/course level } \\
\text { Data notebooks, data walls or other systems of data collection and sharing show that multiple sources of information are used to regularly track and } \\
\text { analyze student progress against goals } \\
\text { School visits and discussions with staff reveal consistent and effective processes for planning for and monitoring instructio nal improvement } \\
\text { School visits and records show that school improvement teams develop plans for improving instruction based on school goals } \\
\text { Written instructional improvement and intervention plans are supported by strong rationales, based on evidence of what works in the school or with } \\
\text { similar students } \\
\text { Staff surveys meet school or district targets for reported effectiveness of school improvement, communication and/or change management } \\
\text { strategies } \\
\text { Other: }\end{array}$}} \\
\hline & & & \\
\hline Notes: & & & \\
\hline
\end{tabular}




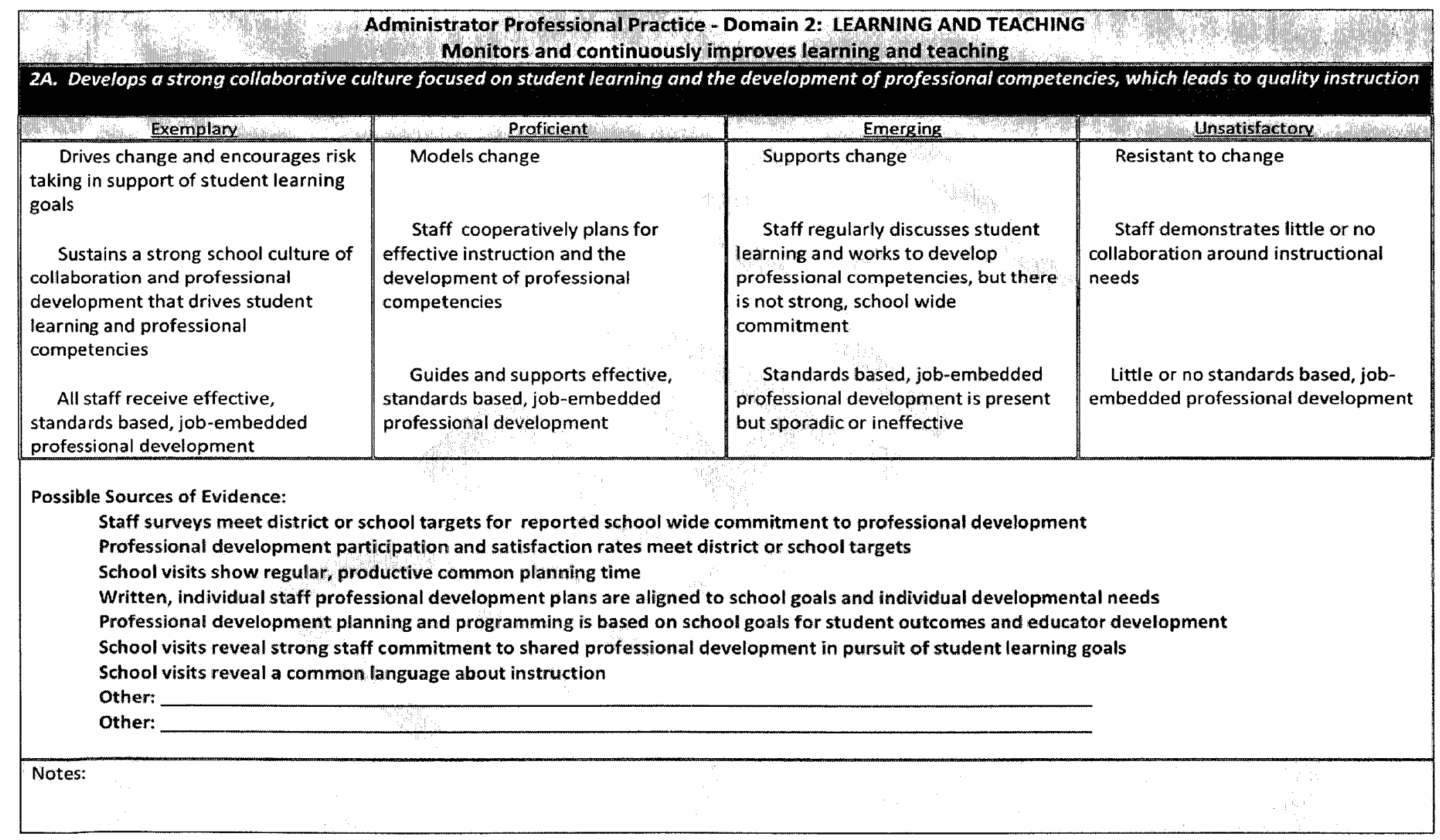


2B. Ensures the implementation of effective, research-based instructional practices aligned with Rhode lsiand and national standards

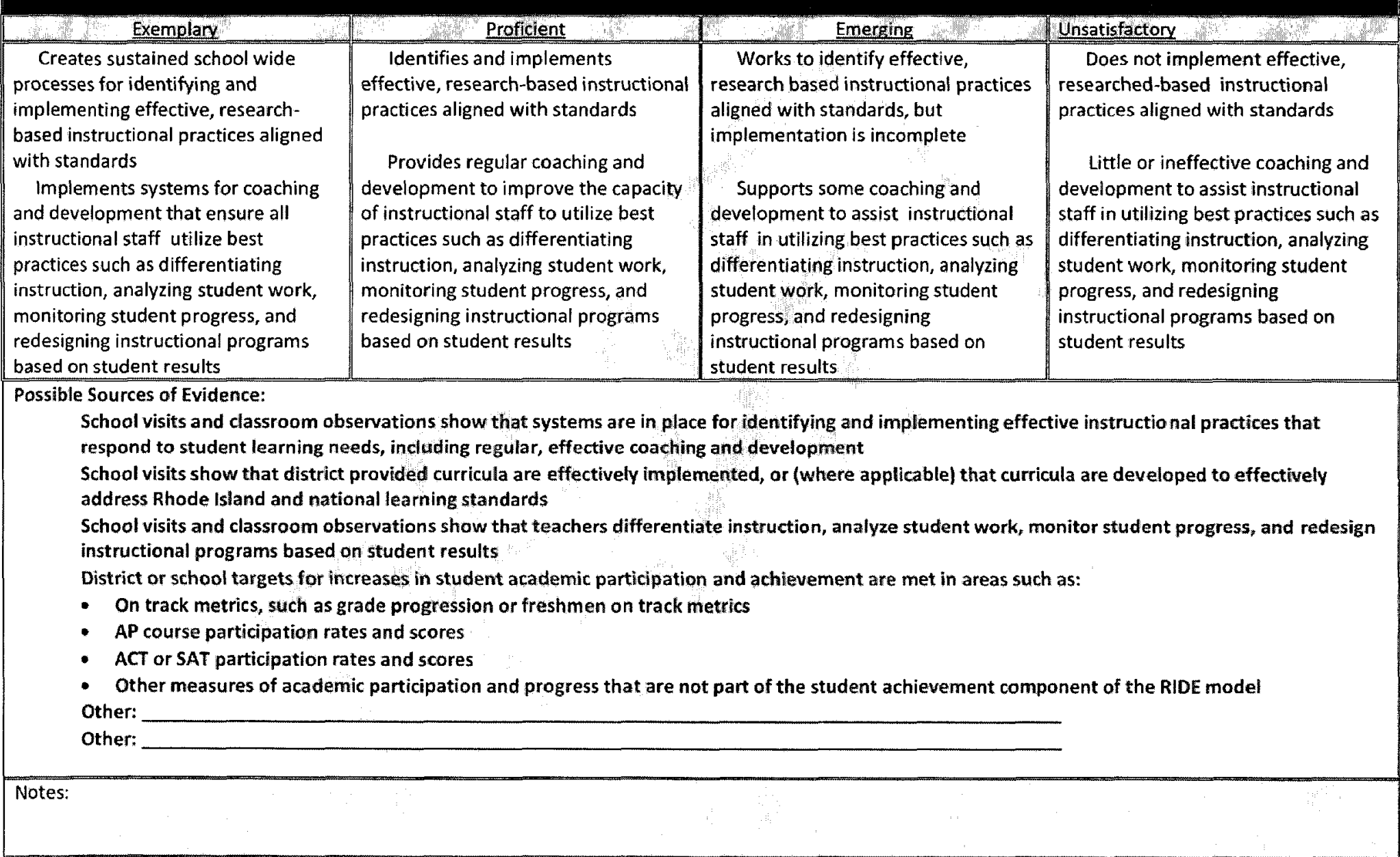




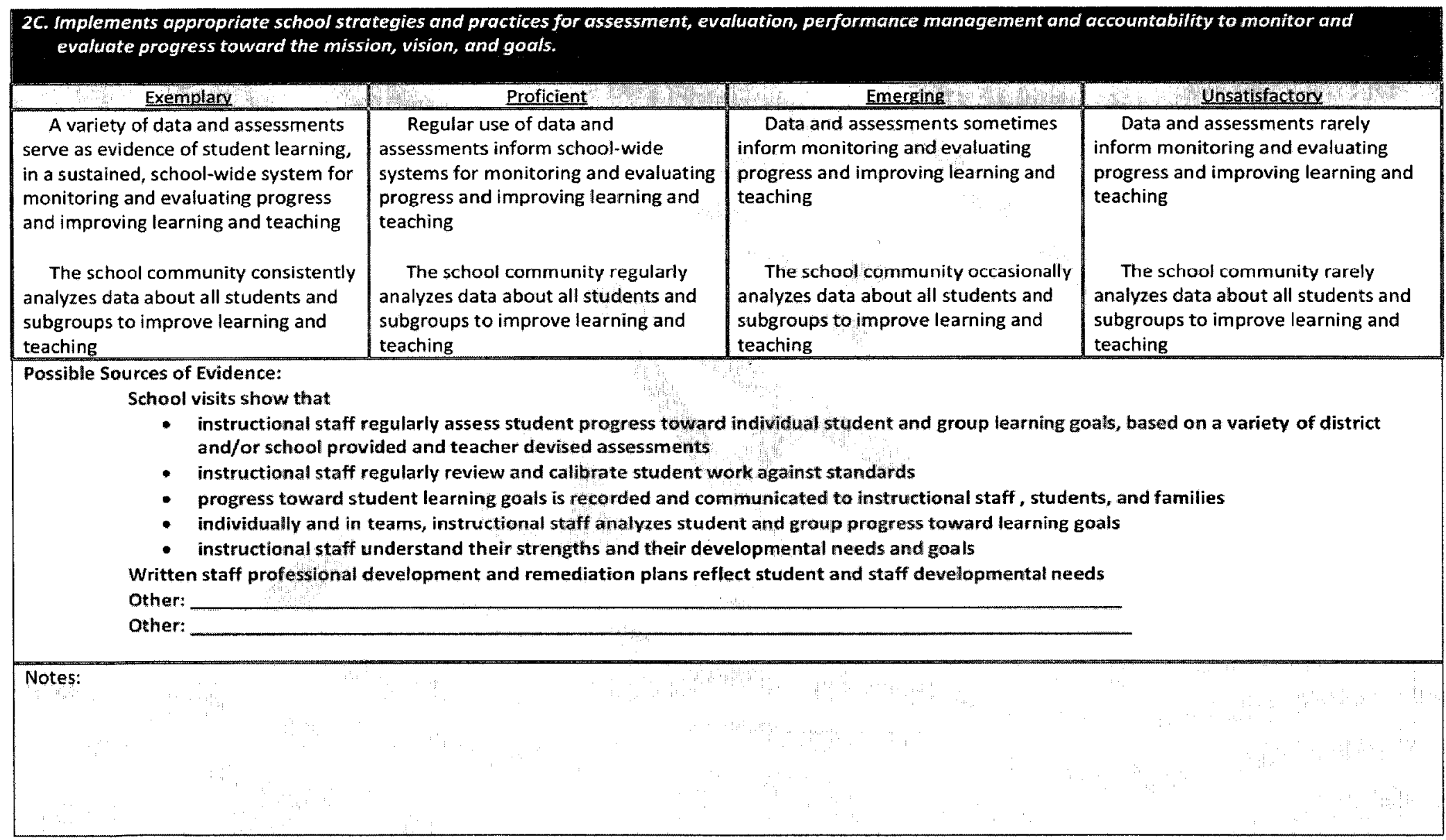

